\title{
Desmids (Conjugatophyceae, Viridiplantae) from the Czech Republic; new and rare taxa, distribution, ecology
}

\author{
Jan ŠŤASTNÝ \\ Department of Botany, Charles University, Benátská 2, CZ-128 01 Prague \\ T. G. Masaryk Water Research Institute, p.ri., Podbabská 30, CZ-160 62, Prague
}

\begin{abstract}
The present work summarizes the current diversity, distribution and autecology of desmids found within the Czech Republic; the focus is on the occurrence and autecology of rare taxa. Data are based on the author's extensive sampling from 2003-2009, during work for both his master's degree, and currently, his Ph.D. dissertation. Over 1400 samples were collected, from various types of wetland habitats ranging from eutrophic fishponds, diverse bogs and fens, to ephemeral pools and various aerophytic habitats. Altogether, 526 taxa of desmids (401 species) belonging to 27 genera were found, 80 of them newly described in the Czech Republic. In the present work, 169 rare or otherwise noteworthy taxa, belonging to the following genera: Mesotaenium (1), Netrium (1), Roya (2), Tortitaenia (1), Gonatozygon (2), Closterium (14), Haplotaenium (2), Pleurotaenium (3), Docidium (1), Actinotaenium (6), Euastrum (9), Micrasterias (7), Cosmarium (78), Xanthidium (7), Staurodesmus (4), Staurastrum (25), Cosmocladium (2), Sphaerozosma (2), Hyalotheca (1) and Desmidium (1) are depicted by line drawings and briefly discussed with regard to their ecology, taxonomy or distribution within the Czech Republic or Central Europe. In addition, SEM images are provided for 45 taxa, and, finally, a comprehensive table is included with indicative notations concerning all taxa found.
\end{abstract}

Key words: bioindicators, Czech Republic, desmids, distribution, ecology, rare taxa, species diversity

\section{Introduction}

Although the study of desmids has a very long tradition in the Czech Republic (ŠŤASTNÝ 2005), and many studies carried out in this country have been considered, at least in part, with this group of algae, knowledge of the diversity and distribution of desmids in the Czech Republic remains scarce. This is largely due to the extremely small number of high-quality, specialized publications appearing over the past 40 years, and to the fact that many works, particularly older ones, lack algal illustrations, and therefore, their data must be regarded with much reserve. Moreover, due to the recent negative impact of human activity (acidification, eutrophication), which causes changes in the nature of wetland biotopes (LEDERER 1998; KouwETs 1999), it is highly probable that the majority of previously acquired data is at present already invalid or obsolete. This, unfortunately, also applies to the localities that were once the most desmid-rich within the Czech Republic (see PASCHER 1903，1906; LÜTKEMÜLLER 1910; JAPP 1930b; RosA 1951; RUீŽIČKA 1973) that currently have either been destroyed, or their character has been completely altered.

The primary objective of the present work was to remedy the above-mentioned lack of reliable data on the occurrence and distribution of desmids in the Czech Republic, and the pragmatic reason for this undertaking is that the material is simply too voluminous to publish in the form of a journal article.

However, the present work was not designed to be a true flora, like e.g. RƯŽIČKA (1977, 1981), LENZENWEGER (1996, 1997, 1999, 2003b) or Coesel \& Meesters (2007). These works are sufficient for a routine determination of desmids from the Czech Republic, because they are aimed at desmids from climatically similar regions, and, as they are adequate and quite satisfactory I thought it more effective to avoid overlapping descriptions or accounts of common taxa. Instead, it seemed much more consequential to focus in greater detail on rare, often poorly known, taxa, some of them even not mentioned in any of the floras mentioned above.

A fundamental problem in the traditional desmid taxonomy based upon morphology is the frequent descriptions of new taxa based 
on unsubstantiated evidence of only slight morphological differences; this fails to take into account the natural morphological plasticity of the particular taxa (RŮŽIČKA 1955b; GRÖNBLAD \& RŮŽIČKA 1959; KouwETS 1988, 2008). Therefore, where possible, all taxa discussed herein (especially little-known taxa), were illustrated by more than one drawing to demonstrate the extent of their morphological variability. Moreover, for every taxon some basal data [dimensions, reference to sampling sites, most frequently used synonym(s)] are listed, and each taxon is briefly discussed with respect to publications reporting it from the Czech Republic, and where available, some notes concerning its taxonomy or autecology are attached.

As an overview of all taxa found and to allow a quick retrieval of basal information concerning a particular species, a comprehensive, notated table is included (Table 1). In this table, analogically to Coesel (1998a), the following aspects of the ecology of every taxon are evaluated:

Trophic state of the habitat. Three classes are distinguished: oligotrophic(low concentrations of nutrients, little aquatic biomass), mesotrophic (moderately rich in nutrients) and eutrophic (high concentrations of nutrients, large aquatic biomass).

Acidity. Three classes are distinguished: acidophilous (occurring at $\mathrm{pH}<6.5$ ), circumneutral $(\mathrm{pH}$ 6.5-7.5) and alkaliphilous $(\mathrm{pH}>7.5)$.

Life form. Three types are distinguished: atmophytic (living in a thin water film of wet, periodically desiccating substrates), benthic (living on the under-water soil or associated with submerged aquatic plants) and planktonic (living in large water bodies, passively floating).

Rarity. Three categories are distinguished: (1) occasional occurrence; (2) rare; (3) very rare. Common and easily confusable species (in particular some small, smooth-walled Cosmarium taxa or some Staurastrum species with arm-like processes) are not labeled.

Ecological sensitivity. This parameter reflects the maturity and degree of inner complexity of the ecosystem that a particular species is indicative of, and, indirectly, also indicates its vulnerability, and the time necessary for its restoration. Clearly, the more complex (internally differentiated) an ecosystem, the more susceptible it becomes to being disturbed, and the more time is required for its restoration (COESEL 1998a, 2001). Marks range from 1 (moderately indicative, occurring also in earlier succession stages) to 3 (most indicative; the species in question seems to be characteristic of highly structured, finely balanced ecosystems). Taxa with a wide ecological amplitude, not being indicative of a vulnerable habitat type, and taxa easily confused with others were not labeled.

Contrary to Coesel (1998a), and to preclude inaccuracies, not only all species, but also all infraspecific taxa have been labeled in Table 1 as to their basic parameters, because they often observably represent separate species having ecological demands completely different from the nominate variety (compare e.g. Xanthidium antilopaeum Kütz. and its "var." laeve SCHMIDLE). Moreover, some infraspecific taxa clearly representing only phenotypical forms of the nominate variety (e.g. Micrasterias americana RALFS var. boldtii GUTw.) were not included in the table. All values for individual parameters listed (particularly "rarity" values) are based only on the author's personal opinion, records and experience; earlier records were not considered. Therefore, the data reflect only the current situation, but considering the large number of samples they are based upon, and the wide spectrum of habitats they represent, they can be presumed to be representative of the Czech Republic as a whole, although the true current biodiversity of desmids within the Czech Republic is undoubtedly somewhat greater. For instance, ŠTĚPÁNKOVÁ et al. (2008) reported some species from the Jizerské hory Mts not included in Table 1, and the author himself found several taxa that he was unable to identify reliably; some of these will be described as new species elsewhere.

The last-mentioned parameter (ecological sensitivity of the individual species), may provide additional (next to e.g. species diversity), interesting information about the particular habitat sampled. It has been put into practice by Coesel who used the fact that desmids are ecologically highly sensitive bioindicators and developed a complex method for evaluating and quantifying the nature conservation value of a given aquatic site based on the vulnerability of the ecosystem as indicated by the composition of its desmid flora (Coesel 1998a, 2001; see also Coesel 2003 and Coesel \& Meesters 2007; CD attached). Principally, this method is based on three criteria (species diversity, the occurrence of rare species and the occurrence of ecologically sensitive 
species), and has been primarily tailored to Dutch conditions, but, as mentioned by Coesel himself, it might also be applicable in geographically similar areas, which would include the Czech Republic. The very processes of evaluation and collection of the data necessary for the assessment of nature values (particularly the transformation schemes for individual water types) are suitable for Czech conditions, and may be found in the abovementioned publications (COESEL 1998a, 2001; Coesel \& Meesters 2007; CD attached) along with some examples of the method's application.

Nevertheless, there are some differences between these two countries, and due to considerable contrast particularly as concerns the rarity of some taxa in both countries, it seemed more accurate to calibrate the species-related data according to the Czech conditions, as summarized in Table 1.

\section{Material and methods}

The samples were taken from various types of wetland habitats ranging from eutrophic fishponds, diverse bogs and fens, to ephemeral pools and various aerophytic habitats. The sampling sites are designated on a map (Fig. 1).

The algal material was collected by squeezing out dominant aquatic plants and mosses and aspirating the algae from the sediment with a syringe. Plankton was sampled using a plankton net with 20 or $40 \mu \mathrm{m}$ mesh. Environmental variables ( $\mathrm{pH}$, conductivity) were measured either with Combo HI 98129 (HANNA, Germany) portable instrument or with a $\mathrm{pH}$-meter WTW 330 and conductometer WTW LF 315 (WTW, Germany). Preparations were made by mixing one drop of material with one drop of glycerin, and drawings were made with the aid of a drawing apparatus. The following abbreviations are used in the text: (Syn.) synonym(s); (Dim.) dimensions; (L) length; (B) breadth; (Ls) length without spines; (Lc) length with spines; (Bs) breadth without spines; (Bc) breadth with spines; (I) isthmus; (Occ.) occurrence; (rr) very rare; (r) occasional; (c) abundant; (cc) very abundant; (m) mass occurrence.

Records of the individual taxa within the Czech Republic were ascertained from the publications of LнотsкÝ \& Rosa (1955) and PoulíčKovÁ et al. (2004) and several other sources not included in those works, such as: Roubal (1939), LHotský (1954), S̆IMEK (1992, 1997), Lederer (1998), Lederer et al. (1998), Neustupa et al. (2002), Šejnohová et al. (2003), Nováková (2003, 2004), KiTNER et al. (2004), HAŠLER et al. (2008) and ŠTĚPÁNKOVÁ et al. (2008). Taxa that are new for the
Czech desmid flora, are designated with an asterisk $(*)$ before the species name.

For scanning electron microscopy (SEM) glass coverslips $(10 \mathrm{~mm}$ in diameter) were washed with acetone, placed on a heating block, and coated three times with a poly-L-lysine solution (1:10 in distilled water) to ensure better adhesion of the desmid cells. After cooling, a drop of the formaldehyde-fixed material was placed on the glass and when almost dry, it was transferred into $30 \%$ acetone and dehydrated by an acetone series $(30,50,70,90,95,99 \%$ and $2 x$ in $100 \%, 10$ minutes each ). Finally, the cells were dried to critical-point with liquid $\mathrm{CO}_{2}$, subsequently sputter coated with gold and examined using Phenom Desktop scanning electron microscope.

\section{Results and discussion}

\author{
Mesotaenium caldariorum (LAGERH.) HANSG. \\ (Fig. 2) \\ Dim.: L: $35-48 \mu \mathrm{m}, \mathrm{B}: 11.5-12 \mu \mathrm{m}$ \\ Occ.: $36 \mathrm{rr}, 40 \mathrm{rr}$
}

Aerophytic species readily distinguished by the conically attenuated and usually slightly asymmetrical (Coesel \& Meesters 2007) cell poles. It is typically reported from artificial habitats such as rain drain pipes (see CoEsel et al. 2006). Its two previous findings from within the territory of the Czech Republic (CzURDA 1946; KomÁré \& Rosa 1957) were from this type of habitat, however, interestingly, I found it only in natural settings.

\section{*Netrium pseudactinotaenium CoESEL}

(Figs 3-6)

Dim.: L: $36-59 \mu \mathrm{m}, \mathrm{B}: 17.5-20 \mu \mathrm{m}$

Occ.: $1 \mathrm{rr}$ (at an oligotrophic, acidic site with $\mathrm{pH}=4.4$ ), 30r, 102rr

Strictly acidophilous, only very recently described species characterized in particular by plasmatic strings that create the impression of a grooved cell edge (Coesel 2002). To date it has been reported, to my knowledge, only from the type site in The Netherlands; thus, my case constitutes its second global published record. Judging from the nature of my sampling sites, its occurrence is limited to well-preserved biotopes, almost untouched by human activity. 
*Roya cambrica W. et G.S.WEST (Fig. 7)

Dim.: L: 133-171 $\mu \mathrm{m}, \mathrm{B}:$ 6.5-7 $\mu \mathrm{m}$

Occ.: $17 \mathrm{rr}$

Roya cambrica, most likely, is a very rare species, reported within Europe only from Great Britain and Norway (KRIEGER 1937), and recently also from The Netherlands (Coesel \& MeEsters 2007).

\section{* Roya closterioides Coesel (Figs 8-12)}

Dim.: L: 50-125 $\mu \mathrm{m}, \mathrm{B}: 2.5-3.3 \mu \mathrm{m}$

Occ.: 1rr, 6rr, 9rr, 13cc, 17m, 24rr, 25r, 47rr, 99rr

This species has only been described very recently by COESEL (2007). Its cells differ from those of the similar Roya pseudoclosterium (J.RoY) W. et G.S.West described by West \& West (1896) by their fusiform shape, somewhat more irregular curving and, on average, a slightly shorter length. So far, $R$. closterioides is known only from the Dutch type locality, but the frequency of my findings indicates that it is probably not actually rare, but due to its extreme inconspicuousness and insufficient knowledge among researchers it often remains unnoticed or misidentified. From the Czech Republic only $R$. pseudoclosterium has been reported thus far (LÜTKEMÜLLER 1910; ŠTĚPÁNKOVÁ et al. 2008), but the rather short cell length of Lütkemüller's specimens (34-118 $\mu \mathrm{m})$ indicate that his finding may in fact represent the species in question, rather than $R$. pseudoclosterium.

\section{*Tortitaenia bahusiensis (NoRDST. et LüTKEM.) Coesel (Fig. 13) \\ Syn.: Spirotaenia bahusiensis NoRDST. et LÜTKEM. \\ Dim.: L: 25-45 $\mu \mathrm{m}, \mathrm{B}: 10-10.5 \mu \mathrm{m}$; \\ Occ.: $91 \mathrm{rr}$}

Rare, aerophytic species that appears to be more common on artificial substrates (RIETH 1982; TOMASZEWICZ \& HINDÁK 2008; see also ŠŤASTNÝ 2008) than in natural habitats.

Gonatozygon aculeatum HASTINGS (Figs 14-15, 340)

Dim.: L: 87-283 $\mu \mathrm{m}, \mathrm{B}: 7-11 \mu \mathrm{m}$

Occ.: 1r, 4r, 5r, 47rr

In Central Europe, according to RƯŽIČKA (1977), a very rare species, from the Czech Republic previously reported only by RÜžIčKA (1973). The spines of my specimens were rather short, up to $2.5 \mu \mathrm{m}$, the apices typically club-shaped (Fig.
15), only in some specimens from sampling sites no. 1 and 47 similar to that of G. monotaenium DE BARY, i.e. slightly dilated (Fig. 14).

*Gonatozygon brebissonii DE BARY var. alpestre RŮŽIČKA (Figs 16-18)

Dim.: L: 25-65 $\mu \mathrm{m}$, B: 5.5-7.5 $\mu \mathrm{m}$

Occ.: $36 \mathrm{cc}, 40 \mathrm{rr}, 43 \mathrm{rr}$

A rare taxon with a probably arctic-alpine distribution (Kouwets 1997; Š̆̌́ASTNÝ 2008). To date it has been reported only from the type locality in the High Tatra Mountains (RŮŽIČKA 1967) and from the Eastern Pyrenees (Kouwets 1997).

\section{Closterium archerianum CLEve var.} pseudocynthia RŮžIČKA (Figs 19-20)

Dim.: L: 88-118 $\mu \mathrm{m}, \mathrm{B}: 11.5-13 \mu \mathrm{m}$

Occ.: 8rr, 21r, 25r, 29rr, 47r, 48r, 49r, 86rr, 98r, 123r

Published findings thus far only from the type locality (RŮŽIČKA 1973), from several localities in France (Kouwets 1997), from Austria (ŠŤAsTnÝ \& LeNZENWEGER 2008) and from the West of Ireland (John \& Williamson 2009). The taxon under discussion, however, is most probably often confused with the frequently co-occurring (Kouwets 1997; personal observation) and generally much more common $\mathrm{Cl}$. cynthia DE Not., as mentioned by RŮžıčKA (1977).

*Closterium braunii ReINSCH (Figs 21-22)

Dim.: L: 560-634 $\mu \mathrm{m}, \mathrm{B}: 41-45 \mu \mathrm{m}$

Occ.: 47rr

This species is distinguished by its very remarkable cell wall sculpture in combination with the brownish color of the cell wall. In Central Europe is it very rare (RŮŽIČKA 1973), my finding is the first from the Czech Republic. For discussion concerning the characteristic wall-sculpture see Kouwets (1991).

\section{Closterium calosporum WITTR. var. brasiliense} Børges. (Fig. 23)

Dim.: L: 150-205 $\mu \mathrm{m}, \mathrm{B}:$ 9-10 $\mu \mathrm{m}$

Occ.: 1r, 4r, 17rr

According to RŮŽIČKA (1977) in Central Europe a rather common taxon that, however, seems to be rare in the Czech Republic, being formerly reported only by RŮŽIČKA (1973). 
Closterium cornu RALFS var. upsaliense NoRDST. (Figs 24-25)

Dim.: L: 42-67 $\mu \mathrm{m}, \mathrm{B}:$ 4-5.5 $\mu \mathrm{m}$

Occ.: 1rr, 4r, 36r, 37r, 43r, 50rr, 54rr, 100r, 118rr

According to RƯŽIČKA (1977), this taxon is rare in Central Europe, but it is possible that it often remains unnoticed because of its small dimensions. So far only one finding has been reported from the Czech Republic (Roubal 1958). Interestingly, in my samples the alga in question always grew sub-aerophytically. The specimens depicted by Williamson (1997, pl. 1, fig. 5) and designated as $\mathrm{Cl}$. pygmaeum GuTw. also clearly represent the taxon in question.

\section{Closterium delpontei (G.A.KLEBS) Wolle}

(Figs 26-27)

Dim.: L: $530-813 \mu \mathrm{m}, \mathrm{B}: 28-38 \mu \mathrm{m}$

Occ.: 1r, 4r, 9r, 25r, 47rr, 48 rr

Rather rare species of well-preserved mesotrophic habitats. Previous findings from the Czech Republic only from Southern Bohemia (RosA 1951, 1969; Roubal 1959; RŮžIČKA 1973). Note, it was only recently described from Austria (ŠŤASTNÝ \& LENZENWEGER 2008), which is one of the best explored European countries in regards to desmids. Possibly, this might be due to the fact that it is similar to the closely related $\mathrm{Cl}$. lineatum RALFS and the occasionally occurring intermediate forms are very hard to identify (RŮŽǏČKA 1977).

\section{Closterium exile W. et G.S.WeSt (Fig. 28)}

Dim.: L: 80-100 $\mu \mathrm{m}, \mathrm{B}: 7.5-8 \mu \mathrm{m}$

Occ.: 61rr, 113rr, 119rr

This species is readily distinguishable from similar curved Closterium species predominantly by a rounded apex that lacks any light-microscopically visible pore (RŮŽIČKA 1977). It's ecology is also very characteristic; it is usually detected at higher altitudes and typically grows sub-aerophytically. Previous reports of this species within the Czech Republic (RŮŽIČKA 1956, 1957a, 1957b), as well as my present findings, have been from this type of habitat.

\footnotetext{
*Closterium nematodes Joshua var. proboscideum W.B. Turner (Figs 29-31)

Dim.: L: 213-325 $\mu \mathrm{m}, \mathrm{B}: 22.5-30 \mu \mathrm{m}$

Occ.: 4rr, 26rr, 99r
}

(1977) a species found mostly ordinarily in the tropics. Occurrence of the type variety (Cl. nematodes Joshua var. nematodes) is not convincingly documented from Central Europe; var. proboscideum is rare in the region (RŮžIČKA 1977). The characteristic thickening of the cell wall below the apex was well developed in the population from sampling site no. 26 (Fig. 29), on the contrary, in populations from sampling sites no. 4 and 99 it was rather inconspicuous (Figs 30-31).

\section{*Closterium pseudopygmaeum Kouwets}

(Figs 32-33)

Dim.: L: 28-63 $\mu \mathrm{m}$, B: $5.8-7 \mu \mathrm{m}$

Occ.: $36 \mathrm{rr}, 43 \mathrm{r}, 87 \mathrm{rr}$

This species is characterized by its small dimensions, a slanted apex with an apical pore (KouwETs 2001), and occurrence predominantly in ephemeral pools and on wet substrates. However, the pore is often quite inconspicuous and may be easily overlooked, especially in fixed material. Thus far this alga has only been reported from several sites in France (KouwETs 2001).

\section{Closterium pusillum Hantzsch (Figs 34-36)}

Dim.: L: 28-59 $\mu \mathrm{m}, \mathrm{B}:$ 7.5-12 $\mu \mathrm{m}$

Occ.: 7r, 38rr, 104c

Rather rare species of ephemeral habitats. Previous records from the Czech Republic include: LÜTKEMÜLLER (1910, Cl. pusillum var. monolithum Wittr.), Roubal (1959), Rosa (1969) and ŠEJNOHOVÁ et al. (2003).

Closterium subulatum (KüTZ.) BRÉB. (Figs 3738)

Dim.: L: 149-232 $\mu \mathrm{m}, \mathrm{B}: 6-9 \mu \mathrm{m}$

Occ.: $15 \mathrm{r}$ (in the pools), 28rr, 59rr, 121rr

Apparently a quite adaptable species. It is reported most frequently from mesotrophic, slightly acidic to neutral waters (RŮžIČKA 1977; COESEL 1979a; Lenzenweger 1996; Coesel \& Meesters 2007), alternatively, FöRSTER (1965) found it in a peatbog, most likely a markedly more acidic habitat, and moreover, all of my findings came from more or less eutrophic and alkaline habitats. So far only three findings have been reported from the Czech Republic (Rosa 1951, 1968, 1969). 
*Closterium tortitaenoides Coesel (Figs 39-41)

Dim.: L: $51-68 \mu \mathrm{m}, \mathrm{B}: 8-8.5 \mu \mathrm{m}$

Occ.: $24 \mathrm{c}$ (in a strongly acidic, oligotrophic pool)

This species was previously only reliably known from several sites in The Netherlands, but it is possible that it has been confused with $\mathrm{Cl}$. navicula (BRÉB.) LÜTKEM. For notes concerning its taxonomy see CoEsel $(2002,2007)$.

Closterium tumidum JoHns. (Figs 42-43)

Dim.: L: $92-145 \mu \mathrm{m}, \mathrm{B}: 14-18 \mu \mathrm{m}$

Occ.: 35cc, 52rr, 54rr, 73r, 110rr, 112cc, 113c

This species is considered to be rare in Central Europe (RŮžIČKA 1977), and is seldom reported even from neighboring countries (GUTOWSKI \& Mollenhauer 1996; Marhold \& Hindák 1998; LENZENWEGER 2003b). However, it is probably quite abundant in suitable biotopes (oligotrophic, slightly acidic to neutral waters, e.g. mountain brooks or spring areas), where it usually grows sub-aerophytically. This assumption is supported by the relatively numerous findings of this species at such sites in the Czech Republic (DvoŘÁk 1920, 1920/21; Fischer 1924; Rosa 1939, 1951, 1969; RƯŽIČKA 1954, 1957a) as well as by the relative high number of my own records. At site no. 35, I found a very rare form with clearly recognizable apical pores (Fig. 42), the occurrence of which was only mentioned previously by RŮžIČKA (1954, 1957a) .

Closterium tumidum JoHNS. var. nylandicum GröNBLAD (Fig. 44)

Dim.: L: $125-157 \mu \mathrm{m}, \mathrm{B}: 10-11.5 \mu \mathrm{m}$

Occ.: 23r (growing sub-aerophytically)

A rare alga (RŮžIČKA 1977) that might be easily confused with the much more common $\mathrm{Cl}$. cornu RALFS, whose cells, however, are more slender and lack a distinctly inflated ventral side. To date there have been four documented findings from the Czech Republic (Rosa 1939, 1951, 1969; RYBNÍČEK 1958; as $C l$. tumidum).

*Closterium turgidum RALFs var. giganteum (Nordst.) De Toni (Fig. 45)

Dim.: L: 690-812 $\mu \mathrm{m}, \mathrm{B}: 74-85 \mu \mathrm{m}$

Occ.: 9rr, 14rr, 25rr

This species is described as having a cell wall delicately striate, and pyrenoids scattered throughout the chloroplast. In my opinion, it is debatable whether the taxon in question is related to the "real" $\mathrm{Cl}$. turgidum RALFS, because there are considerable differences between both taxa as regards their morphology (see RŮŽIČKA 1977) as well as their ecology; $\mathrm{Cl}$. turgidum is a benthic species of slightly acidic, mesotrophic bogs and fens, while, my findings, by contrast, originate from the tychoplankton of greater water bodies.

*Haplotaenium indentatum Kouwets var. latius Kouwets, morpha (Figs 46-53, 341-342)

Dim.: L: $66-155 \mu \mathrm{m}, \mathrm{B}: 14-18 \mu \mathrm{m}$

Occ.: $1 \mathrm{rr}, 3 \mathrm{cc}, 4 \mathrm{c}$

The taxon in question has only been described rather recently (KouweTs 1991) from France, but is probably often confused with the similar Haplotaenium minutum (RALFS) BANDO that, however, lacks the apical indentation (e.g. pl. 32, fig. 8 in Coesel \& Meesters 2007 most likely represents $H$. indentatum var. latius). My material differs from that of Kouwets (1991) by a shorter cell length resulting in a lower length/ breadth ratio $(\mathrm{L} / \mathrm{B}=5.5-10$, Kouwets reports $\mathrm{L} / \mathrm{B}=11-15)$; however, as these characters were often extremely variable, even within populations from the same sampling site, the description of the taxon in question as a new variety of $H$. indentatum may not be justified. Judging from the nature of my sampling sites, $H$. indentatum var. latius seems to prefer a distinctly acidic and oligotrophic environment, which is in accordance with the data of Kouwets (1991). I recently also found it in the desmid-rich "Schwemm bei Walchsee" bog in Austria in a similar habitat type (ŠT̃ASTNÝ, unpublished; see also LENZENWEGER 2000b; ŠŤASTNÝ \& LENZENWEGER 2008).

\section{Haplotaenium rectum (Delponte) Bando (Figs 54-55)}

Syn.: Pleurotaenium rectum DelPONTE

Dim.: L: 230-310 $\mu \mathrm{m}, \mathrm{B}: 18.5-21.5 \mu \mathrm{m}$

Occ.: 1r, 4r, 5r, 8rr, 19rr, 25r

This species was considered to be quite rare in Central Europe (RŮžIČKA 1977), and the only previous report of it in the Czech Republic was mentioned by RouBAL (1939). 
Pleurotaenium eugeneum (W.B.TURNER) W. et G.S.WEST (Figs 56-58)

Dim.: L: $520-828 \mu \mathrm{m}$, B: $37-47 \mu \mathrm{m}$

Occ.: 1r, 9r, 13rr

The only previous finding of this species in the Czech Republic was stated by Rosa (1951), in Central Europe it is considered to be rare (RŮžIČKA 1977). The specimen from site no. 1 (Fig. 58) differed from "typical" $\mathrm{Pl}$. eugeneum (see RŮžIČKA 1977) as found at sites no. 9 and 13 (Figs 56-57) by, on average, more robust cells slightly tapering toward the apices, and by semicells scarcely having detectable swellings beyond the basal inflation. Nevertheless, their determination as $\mathrm{Pl}$. eugeneum appears to be justified enough, particularly due to the presence of the characteristic whorl of spherical granules at the apices, 9-12 granules being visible in face view (RŮŽIČKA 1977).

\section{*Pleurotaenium simplicissimum GRönBLAD}

(Figs 59-61, 343)

Dim.: L: 573-740 $\mu \mathrm{m}$, B: 32.5-40 $\mu \mathrm{m}$

Occ.: 1rr, 4rr, 5rr

A species easily distinguished by rod like cells, a very slight basal inflation of the semicells, and by truncate apices provided with a whorl of tiny, longish, often inconspicuous granules (Figs 60, 343 ), $8-12$ being visible in face view (RƯŽǏČKA 1977). Interestingly, at sampling site no. 4, I usually found cells with slightly inflated semicells (Fig. 61) that might be considered an anomaly. According to RƯžıčKA (1977), Pleurotaenium simplicissimum is extremely rare in Central Europe.

\section{Pleurotaenium tridentulum (WoLle) W.WeSt (Figs 62-64)}

Dim. (dimensions apply to half-cells only): L: 95-131 $\mu \mathrm{m}, \mathrm{B}: 13.5-15 \mu \mathrm{m}$

Occ.: $30 \mathrm{r}$

A strictly acidophilous, in Central Europe very rare species (RŮŽIČKA 1977), with only one previous finding from the Czech Republic (Roubal 1939). I repeatedly found the alga at this site, always in the form of empty half-cells only, but quite abundant in one of the pools; the occurrence of living specimens at this particular site, or at some other high moors location within the "Modravské slatě" complex, is nonetheless likely.

\section{Docidium baculum RaLFs (Figs 65-66)}

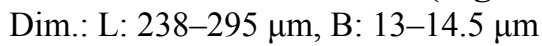

Occ.: $1 \mathrm{r}$

In Central Europe this taxon occurs scattered (RŮŽIČKA 1977), in the Czech Republic it is very rare. Past findings are recorded by PASCHER (1903, 1906), RoubAL (1939) and, more recently, LEDERER at al. (1998); however, the latter, at site no. 99, was not confirmed by my findings.

\section{Actinotaenium cruciferum (DE BARY) TeILING}

(Figs 67-68)

Syn.: Cosmarium cruciferum De BARY

Penium cruciferum (DE BARY) WiTtR.

Dim.: L: 17.5-20 $\mu \mathrm{m}, \mathrm{B}: 10-11.5 \mu \mathrm{m}$

Occ.: $3 \mathrm{rr}, 8 \mathrm{r}$

There are only three earlier findings within the territory of the Czech Republic (Rosa 1951; RŮŽIČKA 1957a; ŠTĚPÁNKOVÁ et al. 2008). $A$. cruciferum might be easily confused with the much more common Cosmarium goniodes W. et G.S.West var. subturgidum W. et G.S.WEST that varies particularly by a somewhat different frontal and lateral view (see Fig. 152).

\section{Actinotaenium inconspicuum (W. et G.S.WEST)}

TeILING (Figs 69-70, 344-345)

Syn.: Cosmarium bacillare LÜTKEM.

Penium inconspicuum W. et G.S.WEST

Dim.: L: $12.5-19 \mu \mathrm{m}, \mathrm{B}: 5-6.5 \mu \mathrm{m}$

Occ.: 1r, 4rr, 5rr, 14rr, 24rr, 43cc

To date only two documented findings from the Czech Republic (RosA 1941; RŮŽIČKA 1973); however, due to its diminutive size it probably often goes unnoticed.

\footnotetext{
* Actinotaenium inconspicuum (W. et G.S.WEST) Teiling var. curvatum Kouwets (Figs 71-72)

Dim.: L: $13-17 \mu \mathrm{m}, \mathrm{B}: 4.5-5 \mu \mathrm{m}$

Occ.: $1 \mathrm{r}$
}

This taxon is as yet known only from several sites in France (KouwETs 1991) and Austria (ŠŤASTNÝ \& LENZENWEGER 2008), however, due to similarity to the nominate variety, it might be easily overlooked. Gontcharov (1998) described A. inconspicuum var. curvatum f. majus that, however, is evidently identical to $A$. infractum (Messik.) Williamson (see Williamson 2007). 


\section{*Actinotaenium kriegeri (MessiK.) Kouwets} (Figs 73-74)

Syn.: A. adelochondrum (ElFVING) TeILING var. kriegeri (MESSIK.) RŮŽIČKA

Dim.: L: 24-30 $\mu \mathrm{m}, \mathrm{B}: 11.5-13.5 \mu \mathrm{m}$

Occ.: 38rr, 43r, 45r, 50rr, 54cc

Rather rare species of oligomesotrophic, ephemeral and hemi-atmophytic habitats (Kouwets 1997). Its characteristic feature are pores with pore-apparatuses increasingly protruding toward the apices (Fig. 73) rendering them seemingly scrobiculate. However, generally only some apical pores are visible (Fig. 74).

\section{*Actinotaenium perminutum (G.S.WEST) \\ TeILING (Figs 75-77) \\ Syn.: Cosmarium perminutum G.S.WEST \\ Cylindrocystis minutissima W.B.TURNER \\ Dim.: L: 10.5-14 $\mu \mathrm{m}$, B: 6.5-7.5 $\mu \mathrm{m}$ \\ Occ.: 1r, 3rr, 4rr, 5rr}

Apparently a rather rare taxon (RŮŽIČKA 1981) that, however, can easily be unnoticed because of its small size.

\section{*Actinotaenium subsparsepunctatum \\ (Grönblad) Coesel (Figs 78-81)}

Syn.: Cosmarium subtile (W. et G.S.WeSt) LütKem. var. subsparsepunctatum GRÖNBLAD

Dim.: L: 14-16 $\mu \mathrm{m}$, B: 9-10 $\mu \mathrm{m}$

Occ.: $37 \mathrm{cc}$

Although I did not find the characteristic zygospores (see CoEsEl 2002; figs 31-32), there is no doubt that the species in question has been identified correctly, because the cell shape, and the structure of chloroplasts (lobostelloid), as well as the ecology of my find site (in an ephemeral puddle) accurately correspond to Coesel's data.

\section{*Euastrum biscrobiculatum (Wolosz.) Coesel (Figs 82-84)}

Dim.: L: 23-33 $\mu \mathrm{m}, \mathrm{B}: 17-24 \mu \mathrm{m}, \mathrm{I}: 5.5-7 \mu \mathrm{m}$

Occ.: 1r, 4rr, 5rr

This species is marked by its striking cell wall sculpture consisting of a combination of tubercles, scrobiculae and grooves (COESEL \& MeEsters 2007). Apparently it is very rare, and judging from the nature of the sampling sites where I found it, its occurrence seems to be limited to well-preserved biotopes with a high desmid diversity. However, it has a complicated taxonomy and might be readily confused with similar taxa (see Coesel 1984a, 2007). Interestingly, at site no. 1 in general I found exclusively larger cells possessing two central scrobiculae (Figs 82-83), on the other hand, at my other sites I found specimens with distinctly smaller cells having only one central scrobicula (Fig. 84).

\section{*Euastrum brevisinuosum (NoRDST.) Kouwets var. dissimile (Nordst.) Kouwets (Figs 85-90) Dim.: L: 21-27 $\mu \mathrm{m}, \mathrm{B}$ : 16-18.5 $\mu \mathrm{m}$, I: 9-10 $\mu \mathrm{m}$ Occ.: $84 \mathrm{c}$}

This rather rarely found taxon (KouwETs 1984) was from the same sampling site reported already by ŠKALOUD (2004, 2009), but wrongly labeled. For details regarding its taxonomy see Kouwets (1984).

*Euastrum crassicolle P.Lundell (Figs 91-92, 346)

Dim.: L: $23.5-27 \mu \mathrm{m}, \mathrm{B}: 12.5-14.5 \mu \mathrm{m}, \mathrm{I}: 5-6 \mu \mathrm{m}$

Occ.: 43r, 50rr

From the Czech Republic only E. crassicolle var. dentiferum NORDST. has been reported thus far (LÜTKEMÜLLER 1910; RŮŽIČKA 1973); most likely, however, these two varieties are only deviations caused by atypical ecology, e.g. aerophytic growth, which is quite common in this species (RŮŽIČKA 1981). This hypothesis is also supported by my findings at site no. 50, where transitions between the two varieties could be observed even within a single, not very abundant population with an aerophytic growth habit; similar observations of Grönblad have also been mentioned by RŮŽIČKA (1981).

Euastrum crassum RALFS (Fig. 93)

Dim.: L: 135-147 $\mu \mathrm{m}, \mathrm{B}:$ 68-75 $\mu \mathrm{m}, \mathrm{I}: 22-25$ $\mu \mathrm{m}$

Occ.: 19rr, 23rr (at site no. 23 only some empty semicells were found)

In Central Europe this species is considered to be rare (RŮŽIČKA 1981), and from the Czech Republic was it recorded only two times at the beginning of the last century (PASCHER 1903, 1906).

\section{Euastrum germanicum (SCHMIDLE) WILLI KRIEG.} (Figs 94-95, 347-349)

Dim.: L: 52-58 $\mu \mathrm{m}, \mathrm{B}: 41-48 \mu \mathrm{m}, \mathrm{I}: 11-12.5 \mu \mathrm{m}$ Occ.: 1r, 2rr, 9c, 10rr, 11r, 12rr, 25rr (at all sampling sites in the littoral zone among submerged macrophytes, 
particularly Myriophyllum spicatum L.)

The only previous finding from the Czech Republic was mentioned by Rosa (1951). In Central Europe it is considered a very rare species (RŮŽIČKA 1981; LENZENWEGER 2000a); my findings, together with other recent ones (LENZENWEGER 2000b; LENZENWEGER \& WerTL 2001; FeHÉr 2003) indicate, however, that it is somewhat more common than supposed. It evidently prefers naturally slightly eutrophic habitats with luxurious macrophyte vegetation (see also COESEL 1978, 1998a; KOUWETS 1998; Lenzenweger 2000a; FeHÉr 2003).

*Euastrum luetkemuelleri F.Ducell. var. carniolicum (LÜTKem.) Willi KrIEg. (Figs 9697, 350-352)

Dim.: L: $22.5-29 \mu \mathrm{m}, \mathrm{B}: 16-20 \mu \mathrm{m}$, I: $6-7.5 \mu \mathrm{m}$

Occ.: 1r, 3rr, 4r, 5rr, 6rr

New for the Czech flora, according to RƯŽIČKA (1981) and KRIEGER (1937) relatively rare in Central Europe. Not even the nominate variety of this species has been reported from anywhere in the Czech Republic.

Euastrum montanum W. et G.S.WEST (Fig. 98)

Dim.: L: 27-30 $\mu \mathrm{m}, \mathrm{B}: 18-20 \mu \mathrm{m}, \mathrm{I}: 5-6 \mu \mathrm{m}$

Occ.: $31 \mathrm{rr}, 32 \mathrm{rr}$

There are only two previous reports of this species from the Czech Republic; LÜTKEMÜLLER (1910) and NovÁKovÁ (2004).

\section{Euastrum pinnatum RaLfS (Figs 99-102)}

Dim.: L: $127-144 \mu \mathrm{m}, \mathrm{B}: 71-78 \mu \mathrm{m}, \mathrm{I}: 21-23 \mu \mathrm{m}$ Occ.: 4 rr

I consistently found cells with an open sinus, which RŮŽIČKA (1981, pl. 64, 4-5) regards as an anomaly. However, Scottish (Williamson 1997) and Dutch (Coesel \& MeEsters 2007) populations of this species were reported only having cells with an open sinus, therefore, it should not be regarded as anomalous, but as a variable character. E. pinnatum is very rare in Central Europe (RŮŽIČKA 1981), and in the Czech Republic it has been described only twice (PASCher 1903, 1906).

\section{Euastrum turneri W.WEST (Figs 103, 353)}

Dim.: L: $33.5-38.5 \mu \mathrm{m}, \mathrm{B}: 26-28.5 \mu \mathrm{m}$, I: $8.5-9 \mu \mathrm{m}$ Occ.: 1rr, 4rr, 8rr, 114rr

A species with scattered distribution in Central
Europe (RŮŽIČKA 1981), in our territory it is now clearly extremely rare. Previous findings: LÜTKEMÜLLER (1910), JAPP (1930b), Rosa (1951) and RŮŽIČKA (1973). At site no. 114, most probably, the alga in question is not autochtonous but scoured from adjacent bogs situated in Zone I of Šumava National Park, as also indicated by its finding in a minimal abundance (one cell).

Micrasterias apiculata RALFs (Fig. 104)

Dim.: L: $192-260 \mu \mathrm{m}, \mathrm{B}: 180-220 \mu \mathrm{m}$, I: $33-39 \mu \mathrm{m}$

Occ.: 1r, 4r, 5rr, 8rr

Earlier findings from the Czech Republic were reported especially from Southern Bohemia (Pascher 1903, 1906; Dechant 1914; Cejp 1929; RoubAL 1938, 1958; RosA 1951; RŮŽIČKA 1973), and from certain Moravian sites (FISCHER 1920; JAPP 1930b; DvoŘÁK 1932); Sládeček mentions its presence in Padrt'ské rybníky (SLÁDEČEK 1950-51). At present, however, this species must be considered very rare on our territory. RŮŽIČKA (1981) describes its distribution within Central Europe as scattered.

Micrasterias brachyptera P.Lundell (Fig. 105) Dim.: L: $185-237 \mu \mathrm{m}, \mathrm{B}: 144-177 \mu \mathrm{m}, \mathrm{I}: 30-37 \mu \mathrm{m}$ Occ.: 1r, 5rr, 20rr, 103rr

The only findings of this rare species (RƯŽIČKA 1981) from within the Czech Republic were recorded by RoubaL (1939) and LHotskÝ (1954). The latter also mentions another, unpublished finding by K. Rosa from Southern Bohemia. There are only two localities known from Austria (LENZENWEGER 1996), in Germany it is considered to be an endangered species (GutOwsKi \& Mollenhauer 1996).

Micrasterias fimbriata RALFs (Figs 106, 354)

Dim.: L: 222-273 $\mu \mathrm{m}$, B: 197-248 $\mu \mathrm{m}$, I: 30-34 $\mu \mathrm{m}$ Occ.: 1r, 4r, 5r, 8r, 17rr, 19r, 20rr, 103r

Findings from the Czech Republic were reported from Southern (PASCHER 1903; КотеK 1950; RŮŽIČKA 1973) and Northern Bohemia (LнотsкÝ 1954), and from some sites in Moravia [FISCHER 1920, 1924 - as M. apiculata RALFs var. fimbriata (RALfs) Nordst., ČERŇAJev 1931]; recently it appears to be a rare species of slightly acidic, mesotrophic water bodies. In central Europe scattered (RŮŽIČKA 1981). 
Micrasterias furcata RALFs (Figs 107-108)

Syn.: M. radiata (NÄGELI) W. et G.S.WEST

Dim.: L: $144-150 \mu \mathrm{m}, \mathrm{B}: 123-128 \mu \mathrm{m}, \mathrm{I}: 22-23 \mu \mathrm{m}$

Occ.: $5 \mathrm{rr}$

Within Central Europe a very rare species (RŮŽIČKA 1981), from the Czech Republic reported only from three sites (PASCHER 1903; CEJP 1929; JAPP 1930b) so far.

\section{Micrasterias jenneri RaLfs (Figs 109, 355)}

Dim.: L: 122-145 $\mu \mathrm{m}, \mathrm{B}: 90-102 \mu \mathrm{m}, \mathrm{I}: 20-23 \mu \mathrm{m}$ Occ.: 3c, 4c, 69rr

This rare (RŮŽIČKA 1981), strictly acidophilous species has been reported from the Czech Republic only three times to date; from the Šmava Mts. (Pascher 1906), from site no. 3 (Mattauch 1936), and recently also from site no. 69 (ŠTĚ́PÁNKOVÁ et al. 2008)

Micrasterias oscitans RaLFs (Figs 110-111, 356) Dim.: L: 125-145 $\mu \mathrm{m}, \mathrm{B}: 103-138 \mu \mathrm{m}$, I: 23-27 $\mu \mathrm{m}$ Occ.: 4rr

A strictly acidophilous species, extremely rare in Central Europe (RŮžIČKA 1981). In the Czech Republic it has been found only in the Sumava Mts (Pascher 1903, 1906). Moreover, Mattauch (1936) mentions, from sampling site no. 3, $M$. oscitans var. mucronata (Dix.) Wille, which, however, falls within the variability of the nominal variety (see also RŮžIČKA 1981, p. 571) and should not be described as a separate taxon.

Micrasterias pinnatifida RaLFs (Figs 112, 357)

Dim.: L: 60-64 $\mu \mathrm{m}, \mathrm{B}: 62-74 \mu \mathrm{m}$, I: $11.5-14 \mu \mathrm{m}$

Occ.: $1 \mathrm{r}, 5 \mathrm{r}$

Previous findings from the Czech Republic come from Southern Bohemia (PASCHER 1903, 1906; Cejp 1929; Roubal 1939; Kotek 1950; Rosa $1969)$; in the $19^{\text {th }}$ century the species was also found in Moravia (NAVE 1863). In Central Europe it occurs only scattered (RỦŽıčKA 1981), in the Czech Republic it is at present very rare.

\section{*Cosmarium angulare Johns. (Figs 113-115)}

Dim.: L: 30.5-35 $\mu \mathrm{m}, \mathrm{B}: 29-32 \mu \mathrm{m}$, I: 9-10 $\mu \mathrm{m}$ Occ.: 9rr, 59r

A rarely reported species of naturally eutrophic habitats with a well-developed macrophyte vegetation (Kouwets 1991; LENZENWEger \& WERTL 2001) that agrees with the conditions of my finds (samples were collected by squeezing out submerged Myriophyllum spicatum and Ceratophyllum demersum L., respectively).

\section{*Cosmarium basiornatum (GRönblad) COeSEL} (Figs 116-117, 358-360)

Dim.: L: $38-41.5 \mu \mathrm{m}, \mathrm{B}: 28-31 \mu \mathrm{m}$, I: $15-16.5 \mu \mathrm{m}$

Occ.: 7r, 38r, 43r, 45rr, 57rr

Thus far only scarcely reported, but most likely not a really rare alga of ephemeral habitats. COESEL \& Meesters (2007) consider C. basiornatum identical to C. cinctutum NoRDST., as described by NoRDSTEDT (1875).

\section{*Cosmarium berryense Kouwets (Figs 118- 119) \\ Dim.: L: 20-22 $\mu \mathrm{m}, \mathrm{B}: 18-20 \mu \mathrm{m}$, I: 6-6.5 $\mu \mathrm{m}$ \\ Occ.: $2 \mathrm{rr}, 121 \mathrm{r}$}

Very rare species of meso-eutrophic habitats, from the much more common species $C$. humile (F.GAY) NORDST. to be distinguished by differences in general cell shape and cell wall ornamentation. For a detailed discussion concerning its taxonomy see Kouwets (1998). Most likely, the figure of $C$. humile in LeNZENWEgER \& WeRTL (2001, pl. 2, fig. 14) actually represents $C$. berryense.

Cosmarium bireme NoRdst. (Figs 120-121)

Dim.: L: $14-16 \mu \mathrm{m}, \mathrm{B}: 13-15.5 \mu \mathrm{m}, \mathrm{I}: 3.5-4 \mu \mathrm{m}$ Occ.: $47 \mathrm{r}$

Probably rare, but easily confused with some similar taxa (see discussion concerning C. cyclops KOUWETS in KouwETs 2001). Earlier findings from the Czech Republic mentioned by FIscher (1924) and RŮŽIČKA $(1949,1973)$.

\section{*Cosmarium boitierense Kouwets (Figs 122- 124)}

Dim.: L: $16-19 \mu \mathrm{m}, \mathrm{B}: 14-16.5 \mu \mathrm{m}, \mathrm{I}: 4.5-5 \mu \mathrm{m}$

Occ.: 9rr, 10rr

C. boitierense and its var. inambitiosum have been described relatively recently from France (Kouwets 1998). According to the original diagnosis, the latter taxon differs from the nominal variety only by its smaller dimensions, and by having a more or less distinct median protuberance on either side of the semicells instead of a small papilla. However, this character can be 
very similar in both varieties (compare figs 55 and 61 in Kouwets 1998), moreover, the dimensions of both varieties can also vary quite considerably (see also Coesel \& Meesters 2007). Therefore, taking into account the very similar ecological preferences of these varieties (KouwETs 1998), it would be better to consider C. boitierense only a single, albeit morphologically quite variable taxon, probably with a wide distribution in mesoeutrophic habitats, as predicted by KouwETs (1998).

\section{Cosmarium brebissonii Ralfs (Figs 125-126)}

Dim.: L: $82-93 \mu \mathrm{m}$, B: $66-75 \mu \mathrm{m}, \mathrm{I}: 22-26 \mu \mathrm{m}$

Occ.: 8c, 29rr

Recently very rare, previous reports from the Czech Republic dating mostly from the first half of the last century (PASCHER 1903, 1906; JAPP 1930b; DvoŘÁK 1932; MaLoch 1937; Roubal 1939; Rosa 1969).

\section{*Cosmarium carinthiacum LüTKEM. (Figs 127- 128)}

Syn.: C. cymatonotophorum W.WeST forma ornata Messik.

C. messikommeri COESEL

Dim.: L: $7.5-8.8 \mu \mathrm{m}, \mathrm{B}: 8.8-10.2 \mu \mathrm{m}, \mathrm{I}: 3-4 \mu \mathrm{m}$

Occ.: $1 \mathrm{r}, 4 \mathrm{r}$

An inconspicuous, very rare taxon of well preserved habitats with a high desmid diversity (see also ŠŤASTNÝ \& LENZENWEGER 2008).

Cosmarium ceratophorum LÜTKEM. (Figs 129, 361-362)

Dim.: L: $31 \mu \mathrm{m}, \mathrm{B}: 25 \mu \mathrm{m}, \mathrm{I}: 7.5 \mu \mathrm{m}$

Occ.: 99rr

An extremely rare species, known from the type site in the Šumava Mts (LÜTKEMÜLLER 1910), from eastern Finland (GRÖNBLAD 1921), and from a bog in Austria (LeNZENwEger 2003b) that is a remnant of a glacial lake (LENZENWEgER 2000b). Therefore, it can be generally considered arctic-alpine and a glacial relict at site no. 99, because the latter also arose during the Quarternary (HÁJEK \& VÍzDAL 1998).
*Cosmarium commissurale RALFS var. acutum BRÉB. (Fig. 130)

Dim.: L: $30-33 \mu \mathrm{m}$, B: 39-42 $\mu \mathrm{m}$, I: $11-12 \mu \mathrm{m}$

Occ.: $53 \mathrm{rr}$

The taxon in question differs from the nominal variety by the acutely attenuated lateral lobes of the semicells, and a differently shaped apex (COESEL \& Meesters 2007), but as shown by Williamson (1997; see also the discussion regarding $C$. pseudocommisurale Kouwets in Kouwets 1991), C. commisurale is a highly variable taxon and intermediate forms may occur. However, all cells I found represented C. commisurale var. acutum, which is considered to be rare in WiLLIAMson (1997) and is new for the Czech flora.

* Cosmarium contractum KIRCHN. var. retusum (W. et G.S.West) Willi Krieg. et Gerloff (Fig. 131)

Dim.: L: 31-35 $\mu \mathrm{m}, \mathrm{B}:$ 30-34 $\mu \mathrm{m}, \mathrm{I}: 10-11 \mu \mathrm{m}$

Occ.: 1rr, 4rr, 5rr, 8rr, 25r

As indicated already by Coesel \& Meesters (2007), this taxon is better kept separate from $C$. contractum, as there are considerable differences in the morphology, as well as in the ecology of these two taxa. Whereas C. contractum prefers oligo-mesotrophic milieu, the majority of my findings of var. retusum were made in mesotrophic habitats, and at site no. 25, as well as in The Netherlands (Coesel \& Meesters 2007), it was even found in a slightly eutrophic and alkaline habitat .

Cosmarium davidsonii J.Roy et BISSET (Figs 132-133)

Dim.: L: $32.5-37 \mu \mathrm{m}, \mathrm{B}: 22-24 \mu \mathrm{m}, \mathrm{I}: 13-14 \mu \mathrm{m}$

Occ.: 50rr, 61rr, 116r, 118r

Rather rare aerophytic species; mentioned in records from the Czech Republic by LÜTKEMÜLLER (1910), RosA (1951) and RUீŽIČKA (1956, 1957a).

*Cosmarium decedens (REINSCH) RACIB. var. minutum (Gutw.) Willi Krieg. et GerlofF (Fig. 134)

Dim.: L: $15.5-18.5 \mu \mathrm{m}, \mathrm{B}: 7-9 \mu \mathrm{m}, \mathrm{I}: 5.5-7 \mu \mathrm{m}$

Occ.: 43rr, 50rr, 54rr

Like the other varieties of $C$. decedens, this alga, too, occurs rather scarcely in ephemeral puddles and on wet soil (LENZENWEGER 1999). 
*Cosmarium dentiferum NoRDST. var. alpinum Messik. (Fig. 135)

Dim.: L: 55-65 $\mu \mathrm{m}, \mathrm{B}: 44-53 \mu \mathrm{m}, \mathrm{I}: 19-21 \mu \mathrm{m}$

Occ.: 61r, 63rr, 73rr, 117rr, 119rr

C. dentiferum var. alpinum is generally reported from oligotrophic, mountainous biotopes (Messikommer 1942; Lenzenweger 1999), which agrees well with my findings and, most likely, the alga discussed is relatively common in such habitats in our territory. No findings of this taxon have been reported from the Czech Republic, but considering the drawing of RYBNíčEK [1958; pl. 3, fig. 39, as C. margaritatum (P.LuNDELL) J.RoY et BISSET], his findings from the Jeseníky Mts probably concern this very alga, a supposition supported by his data on the ecological parameters. Possibly Růžička's record from a very similar habitat (RŮŽIČKA 1956; pl. 3, fig. 29, as $C$. margaritatum forma) also represents $C$. dentiferum var. alpinum., in spite of its somewhat greater dimensions.

\section{*Cosmarium didymoprotupsum W. et G.S.WEST} (Fig. 136)

Dim.: L: $60-70 \mu \mathrm{m}, \mathrm{B}: 52-55 \mu \mathrm{m}$, I: $16-17.5 \mu \mathrm{m}$

Occ.: 1rr, 2r (at both sites in the littoral zone among Myriophyllum spicatum)

Apparently a rather rare tychoplanktonic alga of meso-eutrophic water bodies that, however, might be easily confused by non-specialists with other species exhibiting similar ecological parameters (e.g. C. botrytis Ralfs).

*Cosmarium dilatatum Järnefelt et GRönBLAD (Figs 137-138)

Dim.: L: 10.5-11 $\mu \mathrm{m}, \mathrm{B}: 12-12.5 \mu \mathrm{m}, \mathrm{I}: 3.7-4 \mu \mathrm{m}$ Occ.: 22c (in plankton)

Apparently a very rare taxon of meso-eutrophic, larger water bodies, until present known only from several sites within Europe (BEIJERINCK 1926; JÄRNEFELT \& GRÖNBLAD 1960; COESEL 1989; Kouwets 1998), and from Japan and the Russian Far East (Gontcharov \& Watanabe 1999). However, it might be easily overlooked.

*Cosmarium eichlerianum (Grönblad) Messik. (Figs 139-140)

Syn.: C. rectangulare Grunow var. subrectangulare (LÜtKem. et Grönblad) Willi Krieg. et GerlofF Dim.: L: 37-41 $\mu \mathrm{m}, \mathrm{B}: 30-33 \mu \mathrm{m}$, I: $11-12.5 \mu \mathrm{m}$ Occ.: $1 \mathrm{r}, 5 \mathrm{r}$
Rarely reported taxon of mesotrophic, slightly acidic habitats, new for the Czech Republic. However, the figure of Rosa (1951; pl. 13, fig. 5, as $C$. sexangulare P. LuNDELL) may represent this taxon. The cell wall is often somewhat thickened at the apical and lateral angles, which is not depicted in my drawings.

\section{Cosmarium fastidiosum W. et G.S.WEST (Figs 141-143)}

Dim.: L: $40-53 \mu \mathrm{m}, \mathrm{B}: 35-50 \mu \mathrm{m}$, I: $14-19 \mu \mathrm{m}$

Occ.: 1c

The occurrence of this species is only rarely mentioned in literature (WEST \& WeST 1908; Skuja 1929; Rosa 1951; Coesel 1979b; Coesel \& Meesters 2007; ŠT̃astnÝ \& LenZEnweger 2008), and most authors point to its rather great variability both in size and the development of the cell wall structure in the central part of the cell. These results are confirmed by my findings that showed extreme variability of the central ornamentation, even when comparing two semi-cells of the same cell. It is comprised of at least four, but sometimes many, irregularly placed flat granules, and the only stable feature is the presence of one supraisthmal granula. C. fastidiosum apparently is a very rare species, which seems to prefer mature ecosystems with a great diversity of desmids (see also COESEL 1979b; ŠT̃astnÝ \& Lenzenweger 2008). From the Czech Republic it has only been reported once to date (RosA 1951).

Cosmarium fontigenum NoRdst. (Fig. 144)

Dim.: L: $23-27 \mu \mathrm{m}, \mathrm{B}: 23-27 \mu \mathrm{m}, \mathrm{I}: 7-8 \mu \mathrm{m}$

Occ.: 9rr, 11rr, 25rr, 82c, 86cc

A rather rare species of mesotrophic to slightly eutrophic habitats (see e.g. CoEsel 1998a; LenZenweger 2000b; Fehér 2003). Previous reports from the Czech Republic: LÜTKEMÜLLER (1910), JAPP (1930b), DVOŘÁK (1932), RƯŽIČKA (1957a, 1973).

\section{Cosmarium galeritum Nordst. (Figs 145-146)}

Dim.: L: 55-57 $\mu \mathrm{m}, \mathrm{B}: 43-45 \mu \mathrm{m}, \mathrm{I}: 15-16 \mu \mathrm{m}$ Occ.: 50rr

My specimens differ from forms depicted by Coesel (1991) and LenZenweger (1999), in having only one central pyrenoid, not two; however, this characteristic can be quite variable, sometimes even within a single population (see e.g. 
Kouwets 1997; discussion in section dedicated to Cosmarium homalodermum; RŮžǏČKA 1973; note at C. praemorsum), and therefore, cannot be considered as taxonomically relevant. Also remarkable, and according to the literature, quite rare, was the aerophytic growth habit of my specimens. C. galeritum, so far, has been reported from the Czech Republic only by Roubal (1938).

\section{Cosmarium garrolense J.Roy et BISSET (Figs 147-149)}

Dim.: L: $26.5-32.5 \mu \mathrm{m}, \mathrm{B}: 20-25 \mu \mathrm{m}, \mathrm{I}: 7.5-10 \mu \mathrm{m}$

Occ.: $72 \mathrm{rr}, 100 \mathrm{cc}$

Rather rare aerophytic species, from the Czech Republic previously reported only by RŮžIČKA (1956) and Rosa (1969).

\section{Cosmarium gibberulum LÜTKEM. (Figs 150- 151)}

Dim.: L: 30.5-34 $\mu \mathrm{m}, \mathrm{B}: 26.5-29 \mu \mathrm{m}, \mathrm{I}: 8.5-9 \mu \mathrm{m}$

Occ.: 1r, 9rr, 21rr, 25rr, 55r, 82c, 121r

The morphology of my specimens corresponds well with the original description by LÜTKEMÜLLER (1910; pl. 2., figs 17-20) from the Šumava Mts. It appears that C. gibberulum is a rare tychoplanktonic species of meso-eutrophic, wellpreserved habitats (see also LENZENWEGER 2000b, 2003b).

Cosmarium goniodes W. et G.S.West var. subturgidum W. et G.S.West (Figs 152-154, 363)

Syn.: C. goniodes W. et G.S.WEST var. variolatum W. et G.S.WEST

Dim.: L: $13-20 \mu \mathrm{m}, \mathrm{B}: 7-11 \mu \mathrm{m}$, I: $6-10 \mu \mathrm{m}$

Occ.: 1r, 4rr, 5r, 6r, 8rr, 13rr, 21r, 24rr, 25rr, 36rr, 47rr, 48rr, 55r, 85r, 99rr, 103rr

Curiously, in spite of being recently rather common, this taxon has been reported only twice in the Czech Republic (LÜTKEMÜLLER 1910; RƯŽIČKA 1973). A possible explanation appears to be that it is easily confused with some Actinotaenium species, particularly $A$. cruciferum and $A$. perminutum, which, however, have omniradiate cells whereas, in frontal view, $C$. goniodes var. subturgidum is different from its lateral view (compare Fig. 152).
Cosmarium homalodermum Nordst. (Figs 155156)

Syn.: C. hammeri ReINSCH var. homalodermum (NoRDST.) W. et G.S.WeST

Dim.: L: 59-65 $\mu \mathrm{m}, \mathrm{B}: 52.5-58 \mu \mathrm{m}$, I: 17-18 $\mu \mathrm{m}$

Occ.: 54r, 61rr

Rather rare aerophytic species with a variable number of pyrenoids (one or two, see KouwETs 1997), an observation confirmed by my finding from site no. 54, where cells with either number of pyrenoids were found. Previous reports from the Czech Republic: Fischer (1920, 1922-24), RŮŽIČKA (1956, 1957b).

\section{*Cosmarium jaoi Kouwets (Figs 157-158)}

Syn.: C. garrolense J.Roy et BISSET var. crassum C.C.JAO

Dim.: L: 39-45 $\mu \mathrm{m}, \mathrm{B}: 32-35 \mu \mathrm{m}, \mathrm{I}: 9.5-11.5 \mu \mathrm{m}$

Occ.: 1rr, 2r, 58r, 59r, 120rr, 122r

Kouwets (1998) considers this species very rare, but as indicated by my, and other recent findings (e.g. Lenzenweger \& Wertl 2001; FeHÉr 2003), it is probably quite abundantly distributed in suitable biotopes (particularly in slightly eutrophic habitats with a copious macrophyte vegetation).

\section{Cosmarium kirchneri Børges. (Figs 159, 364)}

Dim.: L: 57-63 $\mu \mathrm{m}$, B: 50-55 $\mu \mathrm{m}$, I: 15-17 $\mu \mathrm{m}$ Occ.: $47 \mathrm{r}$

At the sampling site I found this alga together with $C$. margaritiferum RALFs; in the past $C$. kirchneri had been classified as one of the forms of the latter species [C. margaritiferum forma kirchneri (BørGes.) W. et G.S.West]. However, my observation, similarly to that made by COESEL (1979b), showed two clearly distinguishable taxa, especially as regards the cell wall structure. This corroborates that distinguishing them as two separate species was well justified (for a detailed discussion see also COESEL 1991; Coesel \& Meesters 2007). C. kirchneri is a rare species (contrary to C. margaritiferum, see also LENZEWEGER 1999; p. 137), reported only by RŮŽIČKA (1973; as C. margaritiferum f. kirchneri) from the Czech Republic. 
*Cosmarium klebsii Gutw. (Figs 160-161)

Syn.: C. subtumidum NoRDst. var. klebsii (GuTw.) W. et G.S.WEST

Dim.: L: 27-32 $\mu \mathrm{m}, \mathrm{B}: 26-30 \mu \mathrm{m}, \mathrm{I}: 8-9 \mu \mathrm{m}$

Occ.: 1r, 9r, 11r

Rather rare species of meso-eutrophic habitats with well-developed macrophyte vegetation (see also e.g. LENZEWEGER \& WertL 2001). From the morphologically similar C. subtumidum, as a variety of which it has been classified in the past, is C. klebsii distinguished by its entirely different ecological demands, and also by greater separation between cell wall pores, often marked by short filaments of produced cell material (COESEL \& MeEsters 2007).

*Cosmarium lagerheimii GuTw. (Figs 162-163)

Dim.: L: $16-18 \mu \mathrm{m}, \mathrm{B}: 13.5-16 \mu \mathrm{m}, \mathrm{I}: 4-4.5 \mu \mathrm{m}$

Occ.: 1rr, 9r, $11 \mathrm{rr}$

Very rare species of meso-eutrophic, slightly acidic to alkaline water bodies, new for the Czech flora.

Cosmarium limnophilum SCHMIDLE (Figs 164165)

Dim.: L: 32-37 $\mu \mathrm{m}, \mathrm{B}: 26-30 \mu \mathrm{m}, \mathrm{I}: 8.5-9.5 \mu \mathrm{m}$

Occ.: $1 \mathrm{r}, 5 \mathrm{r}$

A rare (Kouwets 1998) and apparently also morphologically rather variable (see e.g. RŮŽIČKA 1949) species of meso-eutrophic habitats, all of its previous findings within the Czech Republic originate from site no. 15 (RŮŽIČKA 1949, 1973; ŠIMEK 1992, 1997). Intriguingly, the characteristic central ornamentation consisting of three granules arranged in a triangle that is generally considered to be hardly visible in frontal view (see e.g. Kouwets 1991; as C. boeckii WiLle var. isthmolaeve SKUJA; KouwETS 1998), was in my specimens comparatively well recognizable, at least when observing empty cells

Cosmarium medioretusum COESEL (Figs 166169)

Dim.: L: 17-20 $\mu \mathrm{m}, \mathrm{B}: 14-17 \mu \mathrm{m}, \mathrm{I}: 4.5-6 \mu \mathrm{m}$

Occ.: $1 \mathrm{r}$

Very rare taxon, previously found only by RŮžIČKA (1973; as C. subtransiens CROASDALE) in the Czech Republic. Interestingly, LENZENWEGER (1986; as C. umbilicatum LÜTKEM. var. borgei WILlI KRIEG. et Gerloff) and Coesel (2007) report it from localities with a slight environmental disturbance, alternatively, both Czech reports, as well as a very recent finding from Austria (ك̌ŤASTNÝ \& LENZENWEGER 2008), originate from well preserved sites almost untouched by human activity.

*Cosmarium microsphinctum NoRDst. var. crispulum NoRdst. (Figs 170, 365)

Dim.: L: 37-41 $\mu \mathrm{m}, \mathrm{B}: 25-27.5 \mu \mathrm{m}, \mathrm{I}: 14.5-16 \mu \mathrm{m}$

Occ.: 54rr, 66rr

A taxon well distinguished by a thick cell wall, slightly undulate margins and occurrence in hemiatmophytic habitats, especially at higher altitudes. Only the nominate variety of $C$. microsphinctum has been reported in the Czech Republic (RYBNÍČEK 1958).

\section{Cosmarium netzerianum ScHMIDLE (Fig. 171)}

Syn.: C.reniforme (RALFS) W.ARCHER var. apertum W. et G.S.WEST

Dim.: L: 49-56 $\mu \mathrm{m}, \mathrm{B}: 47.5-50 \mu \mathrm{m}, \mathrm{I}: 20-21 \mu \mathrm{m}$

Occ.: $61 \mathrm{rr}$

West \& West (1908) consider C. netzerianum synonymous with their newly described $C$. reniforme var. apertum, and, since that publication, $C$. netzerianum was usually reported in the literature as $C$. reniforme var. apertum. However, in spite of a rough resemblance, $C$. netzerianum should not be considered a variety of $C$. reniforme, due to considerable differences between these taxa in the granulation of the cell wall (see MessiKommer 1942; p.156) and significant differences in their ecology. Whereas C. reniforme is a typical tychoplanktonic species of meso-eutrophic water-bodies, $C$. netzerianum seems to have a clearly arctic-alpine distribution and often grows sub-aerophytically. SCHMIDLE (1895) described it from a site situated $2200 \mathrm{~m}$ a.s.1., furthermore, other findings (e.g. INSAM \& KrIEGER 1936; MEsSIKOMMER 1942; LENZENWEGER 1987, 1994, 2002, 2003a) are from sites at altitudes between 1225 and $2530 \mathrm{~m}$ a.s.l. As for sites in the Czech Republic C. netzerianum is only known from the Krkonoše Mts (BECK-MANNAGETA 1926). 
*Cosmarium norimbergense ReINSCH var. depressum (W. et G.S.West) WiLLI KRIEG. et GERLOFF (Fig. 172)

Dim.: L: $13-16.5 \mu \mathrm{m}, \mathrm{B}: 11.5-15 \mu \mathrm{m}, \mathrm{I}: 4-5 \mu \mathrm{m}$

Occ.: $63 \mathrm{r}$

New for the Czech Republic. To date only $C$. norimbergense var. boldtii (MESSIK.) RŮžIČKA has been reported (RŮžIČKA 1973; pl. 12, figs 6-8), although, when examining Růžička's figures, it appears that a completely different, unrelated taxon is depicted.

Cosmarium notabile BRÉB. (Figs 173-174)

Dim.: L: 25-30 $\mu \mathrm{m}, \mathrm{B}: 18-21 \mu \mathrm{m}$, I: $12.5-14 \mu \mathrm{m}$ Occ.: 36rr, 39rr, 41r, 45rr, 50rr, 61r, 64rr, 73r, 74r, 76r, 77r, 78r, 80rr

Rarely reported, but, judging from the number of my findings, probably a common species of ephemeral, oligo-mesotrophic habitats that, however, usually occurs in small numbers. Earlier reports from the Czech Republic: WÜNSCH (1939), NOVÁČ́EK (1941).

*Cosmarium notatum (Grönblad) Coesel (Figs 175-176)

Syn.: C. jenisejense BoldT var. notatum (GRÖNBLAD) KURT FÖRST.

Dim.: L: 21.5-25.5 $\mu \mathrm{m}, \mathrm{B}: 21.5-26.5 \mu \mathrm{m}$, I: $8.5-9 \mu \mathrm{m}$ Occ.: 1r, 5rr

This alga, in all likelihood very rare in Central Europe, prefers colder areas (see e.g. FÖRSTER 1965; LENZENWEGER 1999); it was, therefore, very surprising that it was found at sites only $275 \mathrm{~m}$ a.s.l. These sites, however, are portions of ponds that were established in the $14^{\text {th }}$ century on the remnants of a glacial lake (NovÁKovÁ \& PopovskÝ 1972) and, perhaps, C. notatum might represent a glacial relict.

Cosmarium novae - semliae Wille var. granulatum (SCHMidLe) SCHMidLe (Fig. 177)

Dim.: L: $14-15 \mu \mathrm{m}$, B: $14.5-15.5 \mu \mathrm{m}$, I: $7 \mu \mathrm{m}$

Occ.: $24 \mathrm{rr}$

Previously reported only by LÜTKEMÜLLER (1910) in the Czech Republic, the occurrence of the nominate variety is mentioned by FISCHER (192224) and JAPP (1930a).
*Cosmarium obsoletum (Hantzsch) Reinsch (Figs 178-179, 366-367)

Dim.: L: $40-45 \mu \mathrm{m}, \mathrm{B}: 47.5-52.5 \mu \mathrm{m}$, I: $22.5-24 \mu \mathrm{m}$

Occ.: $1 \mathrm{r}, 4 \mathrm{c}, 5 \mathrm{r}$

A rare taxon of oligo-mesotrophic, slightly acidic habitats, the occurrence of which seems to be confined to well-preserved biotopes. New for the Czech Republic.

Cosmarium ocellatum B.Eichler et Gutw. (Fig. 180)

Dim.: L: $28.5-30 \mu \mathrm{m}, \mathrm{B}: 25-26 \mu \mathrm{m}, \mathrm{I}: 6-6.5 \mu \mathrm{m}$

Occ.: $25 \mathrm{rr}$

Previous records from the Czech Republic: LÜTKEMÜlLeR (1910), MatTAUCh (1936).

Cosmarium ocellatum B.EICHLER et GuTw. var. notatum (Nordst.) Willi Krieg. et GerlofF (Figs 181-183)

Dim.: L: $25-28 \mu \mathrm{m}, \mathrm{B}: 23-26.5 \mu \mathrm{m}$, I: $6-7 \mu \mathrm{m}$

Occ.: 1r, $4 \mathrm{rr}, 8 \mathrm{r}$

A rare taxon of undisturbed habitats, prior report from the Czech Republic only by RŮžIČKa (1973)

\section{Cosmarium ordinatum (BørGEs.) W. et G.S.WEST} (Figs 184-185, 368)

Dim.: L: $19-22.5 \mu \mathrm{m}$, B: $18-22.5 \mu \mathrm{m}$, I: $6.5-7.5 \mu \mathrm{m}$

Occ.: 1r, 4r, 8r

A quite rare species, in the Czech Republic, to date, reported only by LÜTKEMÜLLER (1910). However, it has become evident that the findings of Rosa (1939; pl. 3, figs. 56-57) and RŮŽIČKA (1973; pl. 10, fig. 12), both published as C. orthostichum P. Lundell refer in fact to $C$. ordinatum; $C$. orthostichum has, indeed, a similar cell wall sculpture, but differs in dimension by nearly twofold (see e.g. Lenzenweger 1999; Coesel \& Meesters 2007).

* Cosmarium ornatulum Coesel (Figs 186-188)

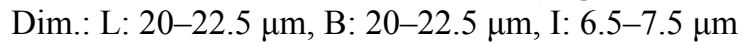
Occ.: 96c, 97r, 106c

Euplanktonic, recently described species (COESEL 2002) of eutrophic, alkaline habitats. In suitable habitats most likely quite common, as indicated by the information received from the hydrobiologist R. Geriš (Geriš, pers.com.), who regularly finds 
it in several eutrophic water reservoirs (Brno, Luhačovice, Mostiště, Plumlov).

\section{*Cosmarium ornatulum Coesel var. depressum Coesel (Fig. 189)}

Dim.: L: $22-23 \mu \mathrm{m}, \mathrm{B}: 25-26 \mu \mathrm{m}$, I: $8 \mu \mathrm{m}$

Occ.: $15 \mathrm{rr}$

This variety differs from the type variety only by the greater breadth of its cells; its ecological requirements are similar (COESEL 2002).

\section{Cosmarium orthopunctulatum Schmide (Figs 190-191)}

Dim.: L: 26-30.5 $\mu \mathrm{m}, \mathrm{B}: 25-28.5 \mu \mathrm{m}$, I: 9-11 $\mu \mathrm{m}$ Occ.: $34 \mathrm{c}, 56 \mathrm{r}, 61 \mathrm{rr}, 62 \mathrm{c}, 67 \mathrm{cc}, 75 \mathrm{rr}, 81 \mathrm{rr}, 117 \mathrm{r}$

A species with a predominantly arctic-alpine distribution (COESEL 1992), as is corroborated by previous reports of it in the Czech Republic (FisCHer 1924; LHOTSKÝ 1949; RYBNíčEK 1958), and by the majority of my findings originating from mountainous regions. My other samplings, from ravines in sandstone rock massifs (sites no. 75 and 81), are interesting from an ecological point of view. These ravines are situated only 450-500 $\mathrm{m}$ above sea level, but due to the inverse character of their climate, the temperatures at their bottom are often very low, comparable to that of much higher altitudes. The cell wall ornamentation can be variable in this alga, as shown by MESSIKOMMER (1942), on the other hand, a characteristic and stable feature is the rounded rhomboid shape of the cells in apical view (Fig. 190).

Cosmarium ovale Ralfs (Figs 192, 369-371)

Dim.: L: 177-195 $\mu \mathrm{m}, \mathrm{B}: 102-113 \mu \mathrm{m}, \mathrm{I}: 34-38 \mu \mathrm{m}$

Occ.: $1 \mathrm{cc}, 5 \mathrm{r}$

Very rare taxon of well-preserved habitats, in the Czech Republic previously recorded only by PAScher (1903, as Cosmaridium ovale HANSG.) and Holzer [1931, as Pleurotaeniopsis ovalis (Ralfs) De Toni].

* Cosmarium paragranatoides SkUJA (Figs 193197, 372-373)

Dim.: L: 24-27.5 $\mu \mathrm{m}$, B: $15-17.5 \mu \mathrm{m}$, I: 5-5.5 $\mu \mathrm{m}$

Occ.: 1c, 4r, 5r, 25rr, 29rr

Relatively rare species of mesotrophic, slightly acidic habitats, new for the Czech Republic.
*Cosmarium parvulum BRÉB. var. undulatum SCHMidLe (Figs 198-200)

Dim.: L: 24-30 $\mu \mathrm{m}$, B: $12.5-13.5 \mu \mathrm{m}, \mathrm{I}: 10-11 \mu \mathrm{m}$

Occ.: $7 \mathrm{r}$

Rare aerophytic taxon, new for the Czech Republic. The occurrence of the nominal variety of $C$. parvulum in the Czech Republic was mentioned by Fischer (1922-24, 1924), RYBNíčEK (1958) and Roubal (1959), however, at least Rybníček's finding, from examination of his figure (RYBNičEK 1958; pl. 2, figs. 33-34), represents a different species, i.e. Actinotaenium obcuneatum (W.WEST) TeILING. The taxon in question might be, if observed in the lateral view, easily confused with Actinotaenium kriegeri, that also has a similar ecology (see above).

\section{*Cosmarium paucigranulatum Borge}

(Figs 201-203)

Dim.: L: $10-11 \mu \mathrm{m}, \mathrm{B}: 9-10 \mu \mathrm{m}, \mathrm{I}: 3-3.5 \mu \mathrm{m}$

Occ.: $51 \mathrm{cc}, 118 \mathrm{cc}$ (in one of the mesotrophic pools)

Initially, my findings were determined to be Xanthidium robinsonianum W. ARCHER var. alpinum Bourrelly, described by BOURRELlY (1987) from Austria (see also LeNZENwEgER 1997; pl. 18, fig. 10). However, the publication is invalid (Kouwets 2001) and, moreover, Bourrelly's material differs from $C$. paucigranulatum, as described by BORGe (1923) in that the sides of semicells are angular instead of rounded, and have a slightly differently developed ornamentation (spinules instead of granules). These characters were already considered almost certainly variable by Kouwets (2001), who regarded both taxa as synonymous, and his conclusion is confirmed by my findings (Figs 201-203). C. paucigranulatum, most likely, is a very rare, but inconspicuous species preferring predominantly mesotrophic, slightly acidic habitats (see BouRRELLY 1987).

* Cosmarium pericymatium Nordst. (Figs 204206, 374-376)

Dim.: L: 41-51 $\mu \mathrm{m}, \mathrm{B}: 26.5-31.5 \mu \mathrm{m}$, I: $21-24 \mu \mathrm{m}$

Occ.: 7r, 90r, 91m, 92r, 94r, 107r, 111rr, 115rr

A species typical for ephemeral, periodically desiccating habitats (see e.g. WILLIAMSON 2000; BRook 2001; Coesel et al. 2006; ŠŤAstnÝ 2008) that, however, seems to be much more common on artificial substrates like concrete than on "natural" substrates, such as wet rocks (see ŠT̃ASTNÝ 2008). 
If observed in the lateral view, the taxon in question might be easily confused with certain Actinotaenium species.

*Cosmarium pericymatium NoRdst. var. corrugatum ВrooK (Figs 207-208, 377-379)

Dim.: L: $60-65 \mu \mathrm{m}, \mathrm{B}: 34-40 \mu \mathrm{m}, \mathrm{I}: 23-26 \mu \mathrm{m}$

Occ.: 91c, 111c

The ecological demands of this taxon are very similar to those of the nominal variety (see ŠŤASTNÝ 2008), thus far it has been exclusively reported from artificial, periodically desiccating substrates (BROOK 2001; WILliamson 2002; ŠŤASTNÝ 2008; ŠŤASTNÝ, unpublished record from The Netherlands). The series of corrugations, being present on each side of the isthmus and giving the taxon in question its name (BROOK 2001) were in my specimen hardly ever visible under the light microscope (Figs 207-208), however, they are clearly distinct if the cells are observed with the aid of a SEM (Figs 377-378). A very similar corrugation along the basis of the semicells, but much more weakly developed than in the var. corrugatum, and visible exclusively under SEM, are sometimes present also in the nominate variety of $C$. pericymatium (ŠŤASTNÝ, personal observation).

*Cosmarium pericymatium NoRDst. var. notabiliforme INSAM et KRIEGER (Figs 209-213) Dim.: L: 26-30 $\mu \mathrm{m}, \mathrm{B}: 15-18 \mu \mathrm{m}, \mathrm{I}: 11-12.5 \mu \mathrm{m}$ Occ.: $52 \mathrm{cc}$

Concerning their general morphology, it is very similar to the nominal variety, however, the cells are much smaller and relatively slightly longer. Very rare, and only known from two sites in Austria (INSAM \& KRIEGER 1936). Notably, the material did not originate directly from the rocks in the "Pohořský" stream, but was collected by squeezing out mosses growing on a short artificial concrete portion of the bed of the stream close to its outflow from the pond, i.e. in a habitat similar to that, where the nominate and the var. corrugatum predominantly occur (see above).

Cosmarium pokornyanum (Grunow) W. et G.S.WeST (Figs 214-215)

Dim.: L: 30-31 $\mu \mathrm{m}, \mathrm{B}: 18-19 \mu \mathrm{m}, \mathrm{I}: 10 \mu \mathrm{m}$

Occ.: $29 \mathrm{rr}$

A rather rare aerophytic taxon that within the
Czech Republic was found only by PASCHER (1903) and Roubal (1938) (both findings as Euastrum pokornyanum GRUNOw).

Cosmarium prominulum RACIB. var. subundulatum W. et G.S.West (Figs 216-217, 380)

Dim.: L: $14.5-17.5 \mu \mathrm{m}, \mathrm{B}: 14-18 \mu \mathrm{m}, \mathrm{I}: 6.5-7,5 \mu \mathrm{m}$

Occ.: 1rr, 3rr, 4rr

Very rare, from the Czech Republic previously reported only by MatTAUCH (1936) from site no. 3.

Cosmarium pseudoexiguum RACIB. (Fig. 218)

Dim.: L: $17-18 \mu \mathrm{m}, \mathrm{B}: 8-8.5 \mu \mathrm{m}, \mathrm{I}: 2.5 \mu \mathrm{m}$

Occ.: 9rr

Previous findings from the Czech Republic: LÜTKEMÜLLER (1910), RŮŽIČKA (1973).

Cosmarium pseudoinsigne Prescott (Figs 219220, 381)

Syn.: C. insigne SCHMidLe

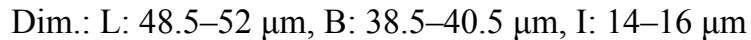
Occ.: $1 \mathrm{rr}$ (in the slightly eutrophic littoral zone), $58 \mathrm{c}$

This rather rare tychoplanktonic species of mesotrophic-eutrophic, found in neutral to slightly alkaline habitats (see e.g. Coesel 1974, 1991; Lenzenweger \& WerTL 2001; FeHÉr 2003) has been reported from the Czech Republic only by Roubal (1938) so far. Often, the cells of the species in question are covered with bacteria, probably feeding on some products secreted by the cell wall pores (Fig. 381).

Cosmarium pseudoprotuberans KIRCHN. (Figs 221, 382-383)

Dim.: L: $31-32 \mu \mathrm{m}, \mathrm{B}: 23-25 \mu \mathrm{m}, \mathrm{I}: 7.5-8 \mu \mathrm{m}$

Occ.: $1 \mathrm{rr}$

Very rare species, reported only twice from the Czech Republic thus far (RosA 1951; RŮŽIČKA 1957a). However, judging from his figures (pl. 2, figs 41-42), Růžička's finding observably represents a completely different species. In addition, LÜTKEMÜLLER (1910) mentions $C$. pseudoprotuberans var. angustius NORDST from the Šumava Mts. 
*Cosmarium pseudoprotuberans KIRCHN. var. sulcatum (NoRdst.) CoEsel (Fig. 222)

Dim.: L: $36.5-40 \mu \mathrm{m}, \mathrm{B}: 29-31 \mu \mathrm{m}, \mathrm{I}: 8-9 \mu \mathrm{m}$

Occ.: 9rr

This variety differs from the nominate only in having the median part of the semicell in apical view triundulate on either long side (COESEL \& MeEsTERs 2007).

*Cosmarium pseudoretusum F.Ducell. (Figs 223-225, 384-385)

Dim.: L: 26-30 $\mu \mathrm{m}$, B: $20-23 \mu \mathrm{m}$, I: $6.5-7.5 \mu \mathrm{m}$

Occ.: $5 \mathrm{c}$

A rare species, from similar taxa distinguished particularly by the papillate outgrowths at the basal angles being commonly present in well developed cells (Figs 223-225).

\section{Cosmarium pseudowembaerense Kouwets (Figs} 226-227)

Syn.: C. laeve RABENH. var. pseudoctangulare F.E.FrITSCH et M.F.RICH

Dim.: L: 14-17 $\mu \mathrm{m}, \mathrm{B}: 13-16 \mu \mathrm{m}, \mathrm{I}: 4-5 \mu \mathrm{m}$

Occ.: 1rr, 2rr, 12rr, 15c, 16rr, 120rr

Relatively rare species of larger, eutrophic and alkaline water bodies (COESEL 1998a; Kouwets 1998; LenZENWEGER \& Wertl 2001). In the Czech Republic previously found by ŠIMEK (1992; as $C$. cf. meneghinii RALFS) at site no. 15, and by HAŠLER et al. (2008).

Cosmarium retusum (PeRty) Rabenh. (Figs 228-230)

Dim.: L: $35.5-42.5 \mu \mathrm{m}, \mathrm{B}: 28-34 \mu \mathrm{m}, \mathrm{I}: 8.5-10 \mu \mathrm{m}$

Occ.: 1r, 4rr

A very rare species (e.g., only two records are known from Austria, ŠŤASTNÝ \& LeNZENWEGER 2008). Findings in the Czech Republic are only by RŮŽIČKA $(1949,1973)$ from one site in southern Bohemia (forms with greatly reduced ornamentation).

\section{*Cosmarium sexnotatum GuTw.}

var. bipunctatum (Wolosz.) CoESEL (Fig. 231)

Dim.: L: 32-35.5 $\mu \mathrm{m}, \mathrm{B}: 27-29 \mu \mathrm{m}, \mathrm{I}: 8.5-9 \mu \mathrm{m}$

Occ.: $1 \mathrm{rr}$

Concerning the general cell shape and ecology, similar to C. limnophilum (see above), but clearly distinguished by the entirely different central ornamentation of the semicells that was usually, contrary to the observations of Coesel (1989) and Kouwets (1998), quite visible, even in frontal view, if empty cells were examined.

*Cosmarium sexnotatum GuTw. var. tristriatum (LÜTKEM.) SCHMIdLE (Figs 232-233, 386)

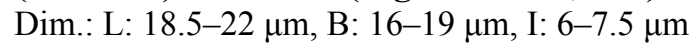

Occ.: 1rr, 4rr

This taxon is, along with the above-mentioned $C$. sexnotatum var. bipunctatum, new for the Czech Republic and apparently rather rare; however, it might be confused with, for instance, C. blytii WILLE var. novae-sylvae W. et G.S.WeST.

Cosmarium simplicius (W. et G.S.WEST) GrönBLAD (Figs 234, 387)

Syn.: C. elegantissimum P.Lundell var. simplicius W. et G.S.WEST

Dim.: L: 44-55 $\mu \mathrm{m}, \mathrm{B}: 21-24 \mu \mathrm{m}, \mathrm{I}: 19-21 \mu \mathrm{m}$

Occ.: 1r, 4rr, 61rr

Previous findings from the Czech Republic reported only by RŮžıčKA $(1949,1956,1973)$ and, evidently, Růžička's findings of C. elegantissimum f. intermedium KAISER (RŮŽIČKA 1956, 1957b) also correspond to the species in question.

*Cosmarium sphyrelatum Coesel (Figs 235240)

Dim.: L: 15-18 $\mu \mathrm{m}$, B: 11.5-14 $\mu \mathrm{m}, \mathrm{I}: 4-5 \mu \mathrm{m}$

Occ.: $1 \mathrm{cc}, 5 \mathrm{rr}$

Relatively recently described species (COESEL 1989), so far known only from The Netherlands, Austria (ŠŤASTNÝ \& LENZENWEGER 2008) and from the Orkneys (Williamson 2003); the latter finding, however, appears to represent a different species. According to the findings of $C$. sphyrelatum thus far, this species seems to prefer mature ecosystems with a high desmid diversity. For SEM images see Coesel (1984b, 1989).

\section{Cosmarium striolatum (Nägeli) W. ArCher} (Fig. 241)

Syn.: C. tesselatum (Delponte) Nordst.

Dim.: L: $125-150 \mu \mathrm{m}, \mathrm{B}: 67-76 \mu \mathrm{m}, \mathrm{I}: 50-60 \mu \mathrm{m}$

Occ.: $1 \mathrm{r}, 5 \mathrm{rr}$

A very rare species with characteristic cell wall ornamentation that was previously reported from the Czech Republic only by Rosa (1951) and RŮŽIČKA (1973). 
*Cosmarium subadoxum GRönBLAd (Fig. 242)

Dim.: L: 9-10 $\mu \mathrm{m}, \mathrm{B}:$ 9-10 $\mu \mathrm{m}, \mathrm{I}: 2-2.5 \mu \mathrm{m}$

Occ.: $1 \mathrm{rr}$

The morphology of my findings corresponds well to the species in question as illustrated by KouwETs (1987; pl. 13, figs 23-25), as well as Coesel \& Meesters (2007; pl. 61, figs 35-36). Characteristic is the presence of a small central papilla on either side of the semicells that is fairly distinct, particularly in the apical view.

\section{Cosmarium subbroomei SCHMIDLE (Figs 243- 244)}

Dim.: L: $35-42 \mu \mathrm{m}, \mathrm{B}: 32-37 \mu \mathrm{m}, \mathrm{I}: 13-14 \mu \mathrm{m}$

Occ.: $15 \mathrm{r}$ (in the pools)

In the Czech Republic this species was only found by ŠImeK (1992, 1997), however, from examination of his figures (ŠIMEK 1997, Fig. 18), it appears that his material is highly consistent with C. subbroomei f. isthmochondrum COESEL (see below). It differs from this taxon only by the absence of the prominent supraisthmal granula on each semicell. However, this character is likely quite variable, as also indicated by my findings (Figs 245-246). Therefore, I believe Šimek's findings most likely represent $C$. subbroomei $\mathrm{f}$. isthmochondrum. The nominate variety of $C$. subbroomei, on the other hand, is characterized by cells with an almost quadrate outline and a somewhat distinct granulation pattern (see e.g. RỦŽIČKA 1972; ŠŤASTNÝ \& LENZENWEGER 2008); see my findings (Figs 243-244).

\section{*Cosmarium subbroomei SchMidLe. f. isthmochondrum CoESEL (Figs 245-246)}

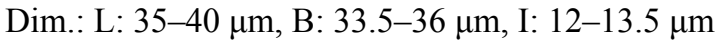
Occ.: $1 \mathrm{r}$

New for the Czech Republic, however, most likely identical to C. subbroomei found by S̆IMEK (1997, Fig. 18) at site no. 15 (see above). Within The Netherlands the taxon in question is predominantly reported from mesotrophic, slightly acidic to neutral habitats (COESEL 1975, as C. subbroomei, 1989), and this is consistent with the conditions of my findings. As indicated by Coesel $\&$ Meesters (2007), the taxon discussed is probably not related to the "real" C. subbroomei and is preferably designated as a separate species.
*Cosmarium subprotumidum NoRdst. var. pyramidale Coesel (Figs 247-248)

Dim.: L: 21-23.5 $\mu \mathrm{m}$, B: $19-21.5 \mu \mathrm{m}$, I: 6-6.5 $\mu \mathrm{m}$

Occ.: 9r, 11r

This taxon is principally distinguished from the somewhat more common, but often co-occurring nominal variety by cells that are pyramidal in outline (in stead of trapeziform, CoEsel \& MeEsters 2007) and have smaller dimensions.

* Cosmarium subquadrans W. et G.S.West var. minor Symoens (Fig. 249)

Dim.: L: $12.5-14 \mu \mathrm{m}, \mathrm{B}: 16-18 \mu \mathrm{m}, \mathrm{I}: 4.5-5 \mu \mathrm{m}$

Occ.: $1 \mathrm{rr}, 3 \mathrm{rr}, 4 \mathrm{rr}, 18 \mathrm{cc}$

The taxon in question is distinguished from morphologically similar taxa by its rhomboid shape in apical view, and by its ecology; it prefers strongly acidic, oligotrophic waters. From the Czech Republic, thus far, only the nominal variety of $C$. subquadrans has been reported (RouBAL 1958).

*Cosmarium subspeciosum Nordst. (Fig. 250)

Dim.: L: $52.5-57.5 \mu \mathrm{m}, \mathrm{B}: 43-46 \mu \mathrm{m}$, I: $15-16 \mu \mathrm{m}$

Occ.: $42 \mathrm{r}$

From the Czech Republic only C. subspeciosum var. transiens has been reported; this, however, represents a completely different, unrelated species. Coesel (1991) labeled a forma that morphologically fully corresponds with my findings C. subspeciosum var. simplicius $\mathrm{J}_{\mathrm{AO}}$, but this variety probably is of little taxonomic significance (see Coesel \& Meesters 2007).

*Cosmarium subtumidum Nordst. var. groenbladii CroasDale (Figs 251, 388)

Dim.: L: 35-39 $\mu \mathrm{m}, \mathrm{B}: 29-32 \mu \mathrm{m}$, I: 10-11.5 $\mu \mathrm{m}$ Occ.: $1 \mathrm{r}, 8 \mathrm{rr}$

To date, only the nominal variety of $C$. subtumidum is known from the Czech Republic (BeCK-Mannageta 1926; JaPP 1930b; DVOŘÁK 1932; Rosa 1933, 1941, 1951, 1969). This differs from the taxon discussed in that the semicells in outline are rounded trapeziform instead of rounded rectangular to hexagonal (COESEL \& MEesters 2007). In addition, the type variety of C. subtumidum lacks the locally thickened cell wall that is usually present and distinct in var. groenbladii (Fig. 251). 
Cosmarium taxichondriforme B.EICHLER et GuTw. (Figs 252-253, 389)

Dim.: L: 40-43 $\mu \mathrm{m}, \mathrm{B}: 40-43 \mu \mathrm{m}$, I: $14-16 \mu \mathrm{m}$

Occ.: 1c, $5 \mathrm{rr}$

Rare species (RŮŽIČKA 1955a; COESEL 1974), in the Czech Republic found only by LÜTKEMÜLLER (1910) and RŮŽIČKA (1973).

Cosmarium tetrachondrum P.Lundell forma (Figs 254-255)

Dim.: L: 20.5-22.5 $\mu \mathrm{m}, \mathrm{B}: 23.5-26.5 \mu \mathrm{m}, \mathrm{I}: 6.5-7.5$ $\mu \mathrm{m}$

Occ.: 1c, $4 \mathrm{rr}$

Very rare, mentioned in the Czech Republic only by RŮŽIČKA $(1949,1973)$ from one site in southern Bohemia.

\section{*Cosmarium truncatellum PERTY (Figs 256-} 261)

Dim.: L: 9-11 $\mu \mathrm{m}, \mathrm{B}: 10-12.5 \mu \mathrm{m}, \mathrm{I}: 6.5-7.3 \mu \mathrm{m}$

Occ.: 30r, 69cc, 70r, 71rr

The morphology and ecology (occurrence in oligotrophic, strongly acidic milieu) of my findings agree very well with the data of KouwETs (1987) and Coesel \& Meesters (2007). The only difference is the shape of the apex that is generally considered to be flat or slightly concave (KouwETs 1987), but in my material, particularly that from site no. 30, a slight inflation at the top of the apex was often visible.

Cosmarium ungerianum (NÄGELI) DE BARY var. subtriplicatum W. et G.S.WEST (Figs 262-263)

Syn.: C. ungerianum (NäGELI) De BARY var. nodosum (ANDERSSON) LÜTKEM.

Dim.: L: 57-65 $\mu \mathrm{m}, \mathrm{B}:$ 51-59 $\mu \mathrm{m}, \mathrm{I}: 18-22 \mu \mathrm{m}$

Occ.: 1c

A very rare alga, within the Czech Republic found only by RŮžIČKA $(1949,1973)$ and RosA (1951).

*Cosmarium variolatum P.Lundell (Figs 264265, 390-392)

Dim.: L: 32-35 $\mu \mathrm{m}, \mathrm{B}: 20-21 \mu \mathrm{m}, \mathrm{I}: 7-8 \mu \mathrm{m}$

Occ.: $1 \mathrm{r}$

A rare taxon, well characterized by a coarsely scrobiculated cell wall (each scrobiculation bears a distinct pore; Figs 390-392).
Cosmarium variolatum P.Lundell var. cataractarum RACIB. (Figs 266, 393-395)

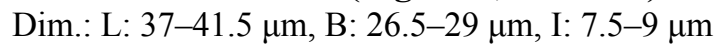

Occ.: 1rr, 9c, 10rr, 11r, 58r

Although (if observed under light microscopy), the cell wall sculpture of this taxon roughly resembles C. variolatum, in the SEM (Figs 393$395)$ it appears completely different. Therefore, and additionally because of the essentially dissimilar ecological demands of these taxa, it appears desirable to distinguish $C$. variolatum var. cataractarum as a separate species. This revision, however, will be published elsewhere. The only report of the taxon in question within the Czech Republic was by HAŠLER et al. (2008).

*Cosmarium varsoviense RACIB. (Figs 267, 396397)

Dim.: L: 38-45 $\mu \mathrm{m}, \mathrm{B}: 34-38 \mu \mathrm{m}, \mathrm{I}: 16.5-18 \mu \mathrm{m}$

Occ.: 1c, 5r, 6rr, 9rr, 25rr, 26rr, 47rr

From the Czech Republic, only $C$. varsoviense RACIB. var. tumidum RỦžIČKA has been reported (ŠIMEK 1992, 1997), but when studying that author's depiction(ŠIMEK 1997, Fig. 19), his finding has no resemblance to $C$. varsoviense, and might represent $C$. rectangulare Grunow. However, LÜTKEMÜLLER (1910) described $C$. lomnicense LÜTKEM. from the Šmava Mts which, most likely, represents the same taxon (see e.g. SkUJA 1934; Krieger \& Gerloff 1965). One of the typical features of the nominate variety of $C$. varsoviense is the presence (in the centre of the semi-cell) of a characteristic structure consisting of a rosette of clearly visible scrobiculae (RACIBORSKI 1889). This structure was always clearly recognizable in my material, at least in cases where I could observe empty cells (see Figs 267, 396-397); however, according to LeNZENWEger (1999) and Kouwets (2001) this feature is often greatly reduced, or even be missing entirely. In the Czech Republic, C. varsoviense seems to be a quite rare species of mesotrophic, slightly acidic habitats.

Cosmarium vogesiacum LemaIRe (Figs 268269)

Syn.: C. bipunctatum Börges.

C. polonicum RACIB.

Dim.: L: 22.5-25 $\mu \mathrm{m}, \mathrm{B}: 20-22.5 \mu \mathrm{m}$, I: $6-8 \mu \mathrm{m}$

Occ.: 4rr, 24r, 31cc, 36r

C. vogesiacum is a morphologically variable species (especially the central ornamentation, 
Kouwets 1987) that is reported particularly from mountainous regions (COESEL 1998b). In the Czech Republic it has been reported only by LÜTKEMÜLLER (1910) and Rosa (1951) under the synonym $C$. bipunctatum. Another of Rosa's findings of $C$. bipunctatum most probably represents, judging from his figure (Rosa 1939; pl. 3, fig. 52), C. ordinatum (see above).

\section{Xanthidium aculeatum EHRENB. (Figs 270-271, 398)}

Dim.: Ls: $67-77 \mu \mathrm{m}, \mathrm{Lc}: 78-95 \mu \mathrm{m}$, Bs: $63-73 \mu \mathrm{m}$, Bc: $77-93 \mu \mathrm{m}$, I: $18-22 \mu \mathrm{m}$

Occ.: $101 \mathrm{cc}$

An extremely rare alga, to date only reported by NAVE (1863) and PAScher $(1903,1906)$ from the Czech Republic. $X$. aculeatum differs from the somewhat similar $X$. brebissonii RALFs by having a relatively greater number of spines not arranged in definite pairs, and by the regular presence of an additional, rather variably developed ornamentation between the central ornamentation and the apex. Therefore, I think it likely that the figure of $X$. brebissonii forma in Coesel \& Meesters (2007; pl. 81; fig. 2), showing a developed subapical ornamentation, actually represents $X$. aculeatum.

\section{Xanthidium basidentatum (Børges.) COESEL} (Fig. 272)

Syn.: $X$. aculeatum EHREnB. var. basidentatum (Børges.) W. et G.S.West

Dim.: Ls: $70-72 \mu \mathrm{m}$, Lc: $85-88 \mu \mathrm{m}$, Bs: $61-63 \mu \mathrm{m}$, Bc: $78-82 \mu \mathrm{m}, \mathrm{I}: 24-25 \mu \mathrm{m}$

Occ.: 1 rr

Very rare, within the Czech Republic reported only twice, by LÜTKEMÜLLER (1910, as X. brebissonii RALFS var. basidentatum BøRGEs.), and by RosA 1969 [as X. fasciculatum var. basidentatum (BøRGES.) RŮŽIČKA]. For a detailed discussion of the taxonomy of this species see Coesel (1993).

\section{Xanthidium bifidum (BRÉB.) Deflandre (Figs 273-275)}

Syn.: Arthrodesmus bifidus BRÉB.

Dim.: Ls: $12.5-17 \mu \mathrm{m}, \mathrm{Bs}: 12.5-17 \mu \mathrm{m}$, I: 5-6 $\mu \mathrm{m}$ Occ.: 1r, 5r, 8rr, 24r

Very rare, but rather inconspicuous alga, reported from the Czech Republic only by PASCHER (1906), RosA (1941) and RŮŽIČKA (1973).
Xanthidium concinnum W.ARCHER (Figs 276277)

Dim.: Ls: $10.5-12.5 \mu \mathrm{m}$, Bs: $11.5-13.5 \mu \mathrm{m}$, I: $3-3.5$ $\mu \mathrm{m}$

Occ.: $47 \mathrm{c}$

An inconspicuous, but probably very rare species, the occurrence of which in the Czech Republic is mentioned by LÜTKEMÜLLER (1910), FISCHER (1924) and Lederer \& SoukuPovÁ (2002). When observed in frontal view, some specimens seem to have several warts directly under the apex; however, these are probably just rough pores (see also Kouwets 1987).

\section{Xanthidium cristatum RALFS (Figs 278-279, 399)}

Dim.: Ls: $45-50 \mu \mathrm{m}$, Lc: $59-66 \mu \mathrm{m}$, Bs: $36-42 \mu \mathrm{m}$, Bc: $49-57 \mu \mathrm{m}$, I: $12-13.5 \mu \mathrm{m}$

Occ.: 1rr, 4rr, 5rr, 8r, 47c, 114rr

Older data on the occurrence of this species in the territory of the Czech Republic are relatively frequent [in Bohemia it was found by PASCHER (1903), Roubal (1939), Rosa (1939, 1951), RŮŽIČKA (1973) and LEDERER et al. (1998), in Moravia by DvoŘÁK $(1910,1934)$, FisCHER (1920), JAPP (1930a, 1930b) and (Holzer 1931)], recently it has become rare.

*Xanthidium cristatum RALFS var. uncinatum RALFS forma polonicum GuTw. (Figs 280-281) Dim.: Ls: $59-64 \mu \mathrm{m}$, Lc: $76-84 \mu \mathrm{m}$, Bs: $50-58 \mu \mathrm{m}$, Bc: $72-77 \mu \mathrm{m}, \mathrm{I}: 17-18 \mu \mathrm{m}$

Occ.: $1 \mathrm{r}$

In the Czech Republic only the nominate forma of $X$. cristatum var. uncinatum has been reported (PASCHER 1903; Fischer 1920; JAPP 1930b; Rosa 1939, 1951, 1969; RŮŽIČKA 1973), which lacks, contrary to the forma polonicum, the granulation of the basal angles.

*Xanthidium fasciculatum RALFS var. oronense W. et G.S.West (Figs 282-283)

Dim.: Ls: $50-55 \mu \mathrm{m}$, Lc: $65-75 \mu \mathrm{m}$, Bs: $45-53 \mu \mathrm{m}$, Bc: $62-70 \mu \mathrm{m}, \mathrm{I}: 15-16.5 \mu \mathrm{m}$

Occ.: $1 \mathrm{r}$

The alga in question is new for the Czech Republic; however, it differs from the nominal variety only by the presence of an additional granula at the semicell base near each of the basal angles (Coesel \& MeEsters 2007) which, with 
respect to the rather considerable morphological plasticity of $X$. fasciculatum (see e.g. RỦŽǏČKA 1955b), might be considered a dismissible feature. Past findings of the type variety within the Czech Republic are relatively frequent. PASCHER (1903, 1906), Dechant (1914), Wünsch (1939) (last two findings as Holacanthum fasciculatum FranzÉ), Rosa (1939, 1951, 1969), Roubal (1958) and RŮŽǏČKA (1973) all mention findings from Bohemia, Moravian findings are recorded by Fischer (1920), JAPP (1930b), DvoŘÁK (1932) and GESSNER (1932). A recent finding from Western Bohemia is mentioned by LEDERER et al. (1998) from site no. 99. However, I could not confirm those records. Of note is that the taxon in question is mentioned by LENZENWEGER (1997; pl. 20, fig. 5) from Austria under the name $X$. fasciculatum var. basidentatum (BøRGES.) RÜŽIČKA that, however, is actually synonymous with $X$. basidentatum (see Coesel 1993).

*Staurodesmus extensus (Borge) TeILING var. joshuae (Gutw.) TeILING (Fig. 284)

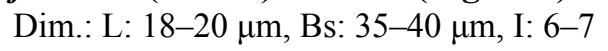

Occ.: 1rr, 8rr, 24rr, 47rr, 114rr

My specimens correspond very well with one of the figures of this taxon in Coesel \& MeEsters (2007; pl. 86, fig. 22), but considering that all cells observed possessed distinctly convergent spines that are atypical for Std. extensus, and, moreover, no intermediate forms (as concerns the orientation of the spines) were found at sites no. 47 and 114, where both taxa mentioned co-occurred, the taxon in question should better be considered a separate species. See also the depiction by RưŽIČKa (1972; pl. 62, fig. 8, as Arthrodesmus triangularis LAGERH.) clearly representing the same alga.

*Staurodesmus extensus (Borge) TeILING var. malaccensis (Bernard) CoESEl (Figs 285-289)

Dim.: Ls: $11-14 \mu \mathrm{m}$, Lc: $20-24 \mu \mathrm{m}$, Bs: 9.5-13 $\mu \mathrm{m}$, Bc: $22-32 \mu \mathrm{m}, \mathrm{I}: 4.5-5.5 \mu \mathrm{m}$

Occ.: 24cc (in a strongly acidic, oligotrophic pool)

The morphology and ecology of my findings agree with the data of Coesel \& Meesters (2007; see pl. 86, fig. 27). This taxon is distinguished from the otherwise very similar Std. phimus (W.B.TURNER) THOMAsson predominantly by its more widely rounded sinus.
*Staurodesmus lanceolatus (W.ARCHER) Croasdale var. compressus (W. et G.S.WEST) Teiling (Figs 290-292)

Syn.: Staurastrum lanceolatum W.ARCHER. var. compressum W. et G.S.WeST

Dim.: L: 19-22.5 $\mu \mathrm{m}$, B: $20-23.5 \mu \mathrm{m}$, I: $6-7 \mu \mathrm{m}$

Occ.: 17r, 47rr, 49rr 51r, 114rr

A rare alga, new for the Czech Republic. However, the figure in RƯŽǏČKA (1973; pl. 14, fig. 8, as Staurastrum brevispinum RALFS var. brevispinum f. minimum LÜTKEM.) most likely represents this same taxon.

*Staurodesmus subhexagonus (W. et G.S.WEST) Coesel (Fig. 293)

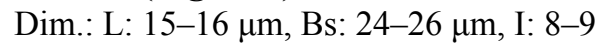

Occ.: 26rr

Concerning the shape of the cell body, similar to Std. extensus var. joshuae (see above), but distinguished by a slightly shorter cell length, and in particular by much shorter spines.

Staurastrum arctiscon (RALFS) P.Lundell (Fig. 294)

Dim.: L: $90-120 \mu \mathrm{m}, \mathrm{B}: 81-118 \mu \mathrm{m}, \mathrm{I}: 21-28 \mu \mathrm{m}$

Occ.: 46rr, $47 \mathrm{c}$

This beautiful tychoplanktonic alga is, within Europe, characterized by a marked atlanticsubarctic distribution, but nowhere is it really common (CoEsel \& KRIENITZ 2008), and in Central Europe is it evidently rare (e.g. LENZENWEGER 1999 mentions the first record from Austria). Only one record has been documented (LÜTKEMÜLLER 1910) from the Czech Republic.

Staurastrum bloklandiae CoEsel et JoOsten (Figs 295-296)

Dim.: L: $27-45 \mu \mathrm{m}, \mathrm{B}: 30-44 \mu \mathrm{m}$, I: 5-6 $\mu \mathrm{m}$

Occ.: 15c, 16c, 27rr, 28rr, 58rr, 60rr, 108rr, 109rr

Although only described relatively recently (Coesel \& Joosten 1996), this species is already known from many European countries, namely: The Netherlands, France, England, Poland, Serbia, Austria (see Meesters \& Coesel 2007), Germany (SCHARF 1985, as Staurastrum cf. caledonense Huber-Pestalozzi) and Slovakia (Tomaszewicz \& HindÁK 2008). In the Czech Republic it was found very recently by HAšLER et al. (2008) and, according to my findings, it seems to be rather common in the plankton of eutrophic water 
bodies.

\section{Staurastrum bohlinianum SCHMIDLE (Figs 297- 298)}

Dim.: L: $22.5-25 \mu \mathrm{m}, \mathrm{B}: 22.5-25 \mu \mathrm{m}$, I: $9-10 \mu \mathrm{m}$

Occ.: 61rr, 68rr

According to LeNZENWEgER (1997), a species with an arctic-alpine distribution, which agrees with my data, as well as with the only previous finding in the Czech Republic recorded from the Krkonoše Mts by Nováková (2004). St. bohlinianum might be easily confused with reduction forms of $S t$. polymorphum RALFS var. pygmaeum GRÖNBLAD that, however, has a different ecology preferring mesotrophic, only slightly acidic habitats situated mostly at lower altitudes.

*Staurastrum crassangulatum COESEL (Figs 299, 400-402)

Syn.: St. kaiseri RưžIČKa (invalid homonym of St. kaiseri PeValek)

Dim.: L: 36-40 $\mu \mathrm{m}, \mathrm{B}: 31.5-37 \mu \mathrm{m}, \mathrm{I}: 9-10 \mu \mathrm{m}$ Occ.: $1 \mathrm{rr}, 5 \mathrm{c}$

From similar, but more common St. bieneanum RABENH. distinguished particularly by the usually thickened cell wall at the lateral angles (Fig. 299).

*Staurastrum cristatum (NÄGELI) W.ARCHER var. cuneatum HiNODE (Figs 300-301)

Dim.: L: 43-48 $\mu \mathrm{m}, \mathrm{B}: 45-53 \mu \mathrm{m}, \mathrm{I}: 22-23 \mu \mathrm{m}$

Occ.: $1 \mathrm{rr}, 5 \mathrm{r}, 114 \mathrm{rr}$

My specimens are identical with those reported under the name St. cristatum var. navigiolum (GrönBLAD) COESEL from a very similar, wellpreserved habitat in Austria by LENZENWEGER (2000a, 2000b). However, both his material, as well as mine, correspond slightly better with St. cristatum var. cuneatum, as the differences between these two taxa are rather small (see Coesel \& Meesters 2007). On site no. 114, most likely, the alga discussed was scoured from neighbouring bogs situated in Zone I of Šumava National Park.

Staurastrum erasum BRÉB. (Figs 302, 403-404) Dim.: L: 33-37.5 $\mu \mathrm{m}, \mathrm{B}: 37-40 \mu \mathrm{m}, \mathrm{I}: 10-11.5 \mu \mathrm{m}$ Occ.: 21r, 46rr, 47rr, 49rr, 51r, 79rr, 86r, 98rr, 114rr

In the Czech Republic there has been only one previous finding of this alga (RŮŽIČKA 1957a) that is well distinguished from similar taxa by bowlshaped semicells. Judging from my findings, it seems to by typical in relatively undisturbed, mesotrophic, slightly acidic to neutral ponds and pools, where it usually occurs among submerged macrophytes; it has often been reported in the literature from similar habitats (see e.g. MESSIKOMMER 1942; RŮŽIČKA 1957a; LENZENWEGER 1997, 2000b).

\section{*Staurastrum eurycerum SkUJA (Figs 303-304)}

Syn.: St. dybowskii Wolosz.

Dim.: L: 18-26 $\mu \mathrm{m}, \mathrm{B}: 32-52 \mu \mathrm{m}, \mathrm{I}: 6-8 \mu \mathrm{m}$

Occ.: 1c, 2rr, 9r, 10rr, 11r, 86r

SKUJA (1948) considers this species euplanktonic, but from the data on its ecology provided by LENZENWEGER (1997), and also from the conditions of my findings (on all sites found in plankton, but at sites no.1, 9, 10 and 86 also found in the littoral zone associated with submerged macrophyte vegetation) it would be better described as a tychoplanktonic alga.

*Staurastrum habeebense IrÉNÉE-MARIE (Figs 305-307, 405-406)

Dim.: L: $36-45 \mu \mathrm{m}, \mathrm{B}: 24-31 \mu \mathrm{m}, \mathrm{I}: 21-23 \mu \mathrm{m}$

Occ.: $91 \mathrm{r}, 93 \mathrm{cc}$

A remarkable species, preferring (unlike most desmids) artificial, periodically desiccating substrata, like roof and drainage gutters or garden ornaments, where it is probably widely distributed, as indicated by its relatively frequent recent findings (Belcher \& Swale 1984; Williamson 2002; CoEsel \& Hindák 2003; CoEsel et al. 2006). For a more detailed discussion of the ecology of Staurastrum habeebense see COESEL \& HINDÁK (2003) and ŠŤASTNÝ (2008).

\section{Staurastrum hystrix RaLFS (Figs 308-309)}

Dim.: Ls: $30-35 \mu \mathrm{m}$, Bs: $26.5-30 \mu \mathrm{m}$, I: $10-11.5 \mu \mathrm{m}$ Occ.: 4r, 24c (at both sites in a strongly acidic, oligotrophic milieu)

Rather rare, strictly acidophilous taxon, from the Czech Republic previously reported only from the Šumava Mts by LÜTKEMÜLLER (1910) and by Mattauch (1936) from sampling site no. 3. 
*Staurastrum lapponicum (SCHMIDLE) GRönbLAD (Figs 310-311, 407-409)

Dim.: L: $31-38 \mu \mathrm{m}$, B: 31-37 $\mu \mathrm{m}$, I: $10-13 \mu \mathrm{m}$

Occ.: 1r, 4rr, 5c, 8r, 9rr, 13r, 14r, 17rr, 24c, 25c, 44rr, 47rr, 48rr, 49rr, 53rr, 86r, 89c, 99c, 105rr

Considering the relatively high frequency of my findings, it is somewhat surprising that this species has not previously been mentioned in the Czech Republic. Possibly, however, it has been mistaken for some forms close to St. punctulatum RaLFs. At present it seems to be relatively common in mesotrophic, slightly acidic habitats.

\section{Staurastrum meriani ReInSCH (Fig. 312)}

Dim.: L: 42-45 $\mu \mathrm{m}, \mathrm{B}: 24-25 \mu \mathrm{m}$, I: $15 \mu \mathrm{m}$

Occ.: $50 \mathrm{r}, 117 \mathrm{r}$

Rather rare species of ephemeral habitats. Previous records from the Czech Republic: PAscher (1906), Fischer (1922-24), BeCK-ManNageta (1929), RŮŽǏČKA (1956, 1957b), Roubal (1958). Apical view usually regularly hexagonal.

\section{*Staurastrum minimum Coesel (Fig. 313)}

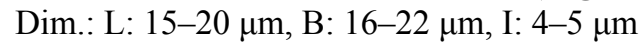

Occ.: $1 \mathrm{cc}, 4 \mathrm{c}, 24 \mathrm{cc}$

To date, this species has been reported only from The Netherlands (Coesel 1996) and France (Kouwets 2001). It has only a few specific morphological features (COESEL \& MEESTERS 2007), however, rather characteristic seems to be its ecology; it prefers more or less oligotrophic, acidic habitats, which corresponds well with the circumstances of my findings.

\section{*Staurastrum oligacanthum W.ARCHER (Figs 314-315)}

Dim.: L: $37.5-42.5 \mu \mathrm{m}, \mathrm{B}: 42-45 \mu \mathrm{m}, \mathrm{I}: 20-22 \mu \mathrm{m}$

Occ.: $1 \mathrm{r}$

New for the Czech flora; however, CoEsel (1997) and LENZENWEGER (1997) point to the considerable similarity and relationship between this species and St. cristatum; it is therefore possible that some findings of St. cristatum within the Czech Republic refer in fact to the alga in question, particularly RosA (1969; pl. 13, fig. 18) and RŮŽIČKA (1973; pl. 16, fig. 2).
Staurastrum orbiculare RALFS var. ralfsii W. et G.S.WEST (Fig. 316)

Dim.: L: 31-37.5 $\mu \mathrm{m}$, B: $27-31 \mu \mathrm{m}$, I: $8.5-9.5 \mu \mathrm{m}$

Occ.: 44r, $114 \mathrm{rr}$

Previous records from the Czech Republic: JAPP (1930b), Rosa (1939), Roubal (1958).

\section{Staurastrum oxyacanthum W.ARCHER (Fig. 317)}

Dim.: L: $26-30 \mu \mathrm{m}, \mathrm{B}: 37-48 \mu \mathrm{m}, \mathrm{I}: 9-11 \mu \mathrm{m}$

Occ.: 1r

This species is usually considered to be rather common (see e.g. LeNZENWEger 1997, 2003b; Coesel \& Meesters 2007); in the Czech Republic, however, it seems to be very rare, having been reported only twice thus far (LÜTKEMÜLLER 1910, as S. oxyacantha W.ArCher, Holzer 1931).

* Staurastrum pentasterias GRöNBLAD (Fig. 318) Dim.: L: 29-31.5 $\mu \mathrm{m}, \mathrm{B}: 35.5-39 \mu \mathrm{m}, \mathrm{I}: 10-13 \mu \mathrm{m}$ Occ.: 1rr, 14rr

A rather variable taxon, as concerns its armlength and thickness, and cell wall ornamentation, on the other hand, the cell length and particularly the radiation of the cells (5-radiate) seem to be quite constant (RƯŽIČKA 1972) and may therefore be used as distinguishing features.

\section{* Staurastrum podlachicum B.EICHLER et GuTw.} (Figs 319-321)

Dim.: L: 33-39 $\mu \mathrm{m}$, B: 37-40 $\mu \mathrm{m}$, I: $13-15 \mu \mathrm{m}$

Occ.: $1 \mathrm{rr}, 114 \mathrm{rr}$

Poorly known species that is considered doubtful by Coesel \& Meesters (2007). However, the morphological characteristics of my specimens were very consistent. Moreover, no intermediate forms were found between this taxon and, for instance, the at site no.1 co-occurring St. oligacanthum (compare Figs 314-315 and 319321), a variety of which St. podlachicum has been previously described (GRÖNBLAD 1920). Therefore, in my opinion, St. podlachicum represents a "good" species. Most probably, on site no. 114 the alga in question was scoured from adjacent bogs situated in Zone I of Šumava National Park, as also indicated by its finding in a minimal abundance (one cell). 
Staurastrum pungens RaLFS (Fig. 322)

Dim.: Ls: $39-46 \mu \mathrm{m}$, Bs: 33-40 $\mu \mathrm{m}, \mathrm{I}$ : $11-12.5 \mu \mathrm{m}$

Occ.: 1rr

A very rare taxon, in the Czech Republic found only by PASCHER $(1903,1906)$.

\section{*Staurastrum quadrispinatum W.B.TURNER (Fig. 323) \\ Dim.: Ls: $28.5-35 \mu \mathrm{m}$, Bs: $27.5-29 \mu \mathrm{m}$, I: $9 \mu \mathrm{m}$ \\ Occ.: 30rr}

A rather rare species of oligotrophic, strongly acidic high moors (PéTERFI 1974; LenZENWEGER 1997). Most likely, the alga occurs also in some of the high moors within the "Modravské slatě" complex.

\section{Staurastrum sebaldi ReINSCH (Fig. 324)}

Dim.: L: $73-87 \mu \mathrm{m}$, B: $75-110 \mu \mathrm{m}$, I: $18-22 \mu \mathrm{m}$ Occ.: 1 rr

In the Czech Republic St. sebaldi is a rare species, previously reported only from four localities (LÜTKEMÜlLER 1910; DvoŘÁK 1932; RouBAL 1939; RosA 1951). In addition, RŮŽIČKA (1973) found the very closely related St. traunsteineri HUSTEDT that might be considered St. sebaldi as well (see e.g. LENZENWEGER 1997; p. 125 and 138).

\section{*Staurastrum setigerum Cleve (Fig. 325)}

Dim.: Ls: $50-56 \mu \mathrm{m}$, Lc: $57-66 \mu \mathrm{m}$, Bs: $43-52 \mu \mathrm{m}$, Bc: $57-68 \mu \mathrm{m}$, I: $14-17 \mu \mathrm{m}$

Occ.: $17 \mathrm{c}, 114 \mathrm{r}$

This species is easily to be distinguished from taxa with a similar ornamentation and ecology by their dimensions; St. teliferum RALFS is distinctly smaller, St. polytrichum (PERTY) RABENH. noticeably larger. Moreover, both those taxa are much more common than St. setigerum. At site no. 114, most likely, the alga in question is not autochtonous but scoured from adjacent bogs situated in Zone I of Šumava National Park.

\section{Staurastrum smithii (G.M.Smith) TeILING (Fig.} 326)

Syn.: St. contortum G.M.Sмiтн

Dim.: L: 37-48 $\mu \mathrm{m}, \mathrm{B}: 43-54 \mu \mathrm{m}$, I: 6-7 $\mu \mathrm{m}$

Occ.: $15 \mathrm{c}, 16 \mathrm{r}, 124 \mathrm{r}$

Probably a quite rare planktont, preferring eutrophic waters (Coesel 1997; LeNZENWEGER 2003b) that, however, is quite probably generally confused with other planktonic Staurastrum species. From the Czech Republic there have been only two findings (PASCHER 1903, 1906).

Staurastrum trapezicum BoLdT (Figs 327-328, 410)

Dim.: L: 50-62 $\mu \mathrm{m}, \mathrm{B}: 55-63 \mu \mathrm{m}, \mathrm{I}: 14-16 \mu \mathrm{m}$

Occ.: 1r, 103r

Previously, this species was reported from the Czech Republic only by Fischer (1922-24, 1924), Holzer (1931), RỦŽIČKA (1956) and NeustuPA et. al. (2002), but at least Růžička's finding, from examination of his figure (RŮŽIČKA 1956; pl. 5, fig. 41), represents a different species, related to St. hirsutum RALFs or its var. muricatum (RALFS) KURT FÖRST.

* Staurastrum varians RACIB. (Figs 329, 411)

Dim.: L: 32-35 $\mu \mathrm{m}, \mathrm{B}: 30-34 \mu \mathrm{m}$, I: $15-16 \mu \mathrm{m}$

Occ.: $1 \mathrm{r}$

From the Czech Republic only the closely related St. acutum BRÉB. has been reported [RABENHORST 1868 , as St. granulosum RALFS var. acutum (BRÉB.) W. et G.S.WEST], which differs in that it has acute lateral angles, instead of rounded as in St. varians (Coesel \& Meesters 2007).

\section{Staurastrum vestitum RaLfs (Figs 330-331)}

Syn.: St. anatinum Cooke et Wills f. vestitum (RALFs) BROOK

Dim.: L: $32-42 \mu \mathrm{m}, \mathrm{B}: 47-84 \mu \mathrm{m}$, I: $12-15 \mu \mathrm{m}$

Occ.: 1c, 4rr, 5r, 8rr, 47r

A rare, morphologically highly variable taxon of well-preserved habitats, closely related to St. aculeatum RALFs as well as to St. anatinum (Coesel \& MeEsters 2007). Its only previous finding in the Czech Republic was mentioned by JAPP (1930b).

Cosmocladium constrictum W.ARCHER (Fig. 332)

Dim.: L: $13.5-15 \mu \mathrm{m}, \mathrm{B}: 8.5-9 \mu \mathrm{m}, \mathrm{I}: 7.5-8 \mu \mathrm{m}$

Occ.: 9c (in plankton)

Notably, in my samplings many large colonies were present, although they only seldom are built up due to the extreme delicacy of their interconnecting slime strands. It is likely that $C$. constrictum is a very rare species, but considering the fragility of their interconnecting strands they may easily be disintegrated in fixed material (COESEL 
1994), and, therefore, a subsequent confusion of individual cells with some representatives of the genus Actinotaenium cannot be ruled out. The only previous finding of this species in the Czech Republic was mentioned by LÜTKEMÜLLER (1910).

Cosmocladium saxonicum DE BARY (Figs 333335)

Dim.: L: 22-24 $\mu \mathrm{m}, \mathrm{B}: 16-17.5 \mu \mathrm{m}, \mathrm{I}: 7-7.5 \mu \mathrm{m}$

Occ.: $98 \mathrm{~m}$ (in plankton)

There is only one previous record of this species in the Czech Republic (LÜTKEMÜlLER 1910). It is probably very rare (for instance, it was only recently, see LENZENWEGER 2002, 2003a, found for the first time in Austria), but, as in the case of $C$. constrictum, fixing with alcohol or formaldehyde causes, in approximately 24 hours (COESEL 2004), a degradation of the colonies due to the disintegration of the interconnecting strands, and individual cells can then be easily mistaken for some smooth-walled representatives of the genus Cosmarium. Interestingly, the occurrence of the representatives of the genus Cosmocladium seems to be markedly ephemeral; both $C$. saxonicum as well as $C$. constrictum were sampled in large numbers in the autumn of 2005, but had already completely disappeared from the sampling sites by 2006; a similar observation was mentioned by Kouwets (Kouwets, pers. com.) for $C$. perissum J.Roy et BisSET.

Sphaerozosma aubertianum W.WEST (Figs 336, 412-413)

Dim.: L: $14-18 \mu \mathrm{m}, \mathrm{B}: 19-27 \mu \mathrm{m}, \mathrm{I}: 5.5-7.5 \mu \mathrm{m}$

Occ.: $47 \mathrm{c}, 83 \mathrm{r}, 88 \mathrm{r}$

A rare species preferring mesotrophic, slightly acidic habitats (RŮžIČKA 1973; KouwETS 1987), from the Czech Republic until now reported only by LÜTKEMÜLLER (1910) and RŮŽIČKA (1973).

\section{Sphaerozosma filiforme RaLfS (Figs 337, 414- 415)}

Syn.: Onychonema filiforme (EHREnB.) J.Roy et BISSET Dim.: L: 10.5-12.5 $\mu \mathrm{m}, \mathrm{B}: 11.5-14.5 \mu \mathrm{m}$, I: 4-5 $\mu \mathrm{m}$

Occ.: 1r, 4rr, 5r, 8rr, 9rr

This species appears to have a relatively broad ecological range; in literature it is usually described from mesotrophic, slightly acidic habitats (see e.g. RŮŽIČKA 1973; COESEL 1994, 1998a; LENZENWEGER 2000b), however it can also withstand slightly eutrophic and weakly alkaline conditions (FeHér 2003). I found it in a similar, slightly eutrophic environment at sampling site no. 1. Previous findings from the Czech Republic: RoubaL (1939), RosA (1969) and RŮŽǏčKA (1973). RoubAL (1958) also mentions its nineteenth-century findings by Corda and Hansgirg in Western Bohemia.

\section{Hyalotheca mucosa RaLFs (Fig. 338)}

Dim.: L: 14-20 $\mu \mathrm{m}, \mathrm{B}: 17-20 \mu \mathrm{m}$

Occ.: $26 c, 33 r r, 42$ r, 46cc, $47 \mathrm{r}$

Much less common than Hyalotheca dissiliens RALFs. Previous findings from the Czech Republic: PAscher (1903, 1906), DVoŘÁK (1919), JAPP (1930a), DvoŘÁK (1932), MaLoch (1937), Roubal (1939), WÜNSCH (1939) and RosA (1951).

*Desmidium baileyi (RALFs) Nordst. var. caelatum (KIRCHN.) NoRdst. (Figs 339, 416417)

Dim.: L: $16-18 \mu \mathrm{m}, \mathrm{B}: 22-24 \mu \mathrm{m}$

Occ.: 1r, 4rr, 5r

A rare taxon; for instance, LenZENwEger (2000a) mentions the first finding in Austria, and notes only two known sites from Switzerland; GUTOwSKI \& Mollenhauer (1996) describe it, probably by mistake, as "a very abundant species, currently not endangered". The nominate variety of $D$. baileyi differs in having cells about as long as they are broad with almost straight lateral sides, and it is particularly known from tropical regions (COESEL \& MeEsters 2007).

\section{Acknowledgements}

I am much obliged to my laboratory colleagues, including Ladislav Hodač, Jiř́i Neustupa, Jana Veselá, Pavel Škaloud, Marie Pažoutová, Helena Bestová, Sylvie Odstrčilová, and to Ludmila Hájková from Masaryk University, Brno, for kindly lending me samples for study. I would also like to thank Rodan Geriš for information concerning the distribution of Cosmarium ornatulum and my sister Zuzana for assisting me with my English. Dr. Frans Kouwets is acknowledged for his kind assistance with SEM preparations. The study was supported by research projects no. 21620828 of the Czech Ministry of Education, no. 0002071101 of the Czech Ministry of Environment and by grant 206/09/0906 of Czech Science Foundation.

\section{References}

Beck-mannageta, G. (1926): Algenfunde im 
Riesengebirge. Ein Beitrag zur Kenntniss der Algenflora des Riesengebirges. - Věst. Král. čes. Spol. Nauk, tř. II, Praha (10): 1-18.

Beck-Mannageta, G. (1929): Algenfunde im Riesengebirge. Ein zweiter Beitrag zur Kenntniss der Algenflora des Riesengebirges. Lotos 77: 93-100.

BEIJERINCK, W. (1926): Over verspreiding en periodiciteit van de zoetwaterwieren in Drentsche heideplassen. - Verh. Kon. Ned. Akad. Wetensch., Afd. Natuurk., 2e Sect. 25: 5-211.

Belcher, J.H. \& Swale, E.M.F. (1984): Unusual and surprising algae from a Cambridge roof. Microscopy 35: 136-143.

Borge, O. (1923): Beiträge zur Algenflora von Schweden. - Ark. f. Bot. 18: 1-34.

Bourrelly, P. (1987): Algues d'eau douce des mares d'alpage de la région de Lunz am See, Autriche. - In: Cramer, J. (ed.): Bibliotheca Phycologica 76. - 182 pp., Gebrüder Borntraeger Verlagsbuchhandlung, Berlin-Stuttgart.

Brook, A.J. (2001): The drought resistant desmid, Cosmarium pericymatium Nordstedt, and a description of the new var. corrugatum. Quekett Journal of Microscopy 39: 127-132.

CEJP, K. (1929): Flóra desmidiaceí horských rašelin šumavských. - Čas. Nár. Mus., odd. př́rodov. 103: 28-32.

Coesel, P.F.M. (1974): Bijdragen tot de kennis der Nederlandse Desmidiaceeënflora 1. Enige interessante soorten uit het plassengebied van N.W. - Overijssel. - Gorteria 7: 20-26.

Coesel, P.F.M.. (1975): Bijdragen tot de kennis der Nederlandse Desmidiaceeënflora 3. N.W. Overijssel (2). - Gorteria 7: 207-213.

Coesel, P.F.M. (1978): Taxonomical, geographical and ecological notes on Euastrum mononcylum, var. germanicum Schmide (Chlorophyta, Desmidiaceae). - Arch. Protistenk. 120: 436445.

Coesel, P.F.M. (1979a): Desmids of the broads area of N.W.- Overijssel (The Netherlands) I. - Acta Bot. Neerl. 28: 257-279.

Coesel, P.F.M. (1979b): Desmids of the broads area of N.W.- Overijssel (The Netherlands) II. - Acta Bot. Neerl. 28: 385-423.

Coesel, P.F.M. (1984a): Notes on the variation, geographical distribution and ecology of Euastrum insulare var. basichondrum (Chlorophyta, Desmidiaceae). - P1. Syst. Evol. 144: 137-147

Coesel, P.F.M. (1984b): Taxonomic implications of SEM revealed cell wall sculpturing in some small-sized desmid species (Chlorophyta, Conjugatophyceae). - Acta Bot. Neerl. 33: 385-398.

Coesel, P.F.M. (1989): Taxonomic notes on Dutch desmids. - Cryptogamie, Algol. 10: 181-193.

Coesel, P.F.M. (1991): De Desmidiaceeën van Nederland. Deel 4, Fam. Desmidiaceae (2). 88 pp., Uitgeverij Koninklijke Nederlandse Natuurhistorische Vereniging, Utrecht.

Coesel, P.F.M. (1992): Desmid assemblies along altitude gradients in Colombia. - Nova Hedwigia 55: 353-366.

Coesel, P.F.M. (1993): Taxonomic notes on Dutch desmids II. - Cryptogamie, Algologie 14: 105114.

Coesel, P.F.M. (1994): De Desmidiaceeën van Nederland. Deel 5, Fam. Desmidiaceae (3). - 55pp., Uitgeverij Koninklijke Nederlandse Natuurhistorische Vereniging, Utrecht.

Coesel, P.F.M.. (1996): Taxonomic notes on Dutch desmids III. - Cryptogamie, Algologie 17: 19-34.

Coesel, P.F.M. (1997): De Desmidiaceeën van Nederland. Deel 6, Fam. Desmidiaceae (4). 95 pp., Uitgeverij Koninklijke Nederlandse Natuurhistorische Vereniging, Utrecht.

Coesel, P.F.M. (1998a): Sieralgen en Natuurwaarden. - 56 pp., Uitgeverij Koninklijke Nederlandse Natuurhistorische Vereniging, Utrecht.

Coesel, P.F.M. (1998b): Desmids from mountain pools in Sierra de Gredos (Central Spain), biogeographical aspects. - Biologia 53: 437443.

Coesel, P.F.M. (2001): A method for quantifying conservation value in lentic freshwater habitats using desmids as indicator organisms. Biodiversity and Conservation 10: 177-187.

Coesel, P.F.M. (2002): New, intriguing desmid taxa from The Netherlands. - Algological Studies 104: 69-79.

Coesel, P.F.M. (2003): Desmid flora data as a tool in conservation management of Dutch freshwater wetlands. - Biologia 58: 717-722.

Coesel, P.F.M. (2004): Cosmocladium saxonicum De Bary: recente vondst van een interessante, zelden waargenomen sieralgsoort. - Gorteria 30: 210-212.

Coesel, P.F.M. (2007): Taxonomic notes on Dutch desmids IV: new species, new names, new combinations. - Syst. Geogr. P1. 77: 5-14.

Coesel, P.F.M. \& Joosten, A.M.T. (1996): Three new planktic Staurastrum taxa (Chlorophyta, Desmidiaceae) from eutrophic water bodies and the significance of microspecies in desmid taxonomy. - Algological Studies 80: 9-20.

Coesel, P.F.M. \& HindÁK, F. (2003): Staurastrum habeebense IRÉNÉE-MARIE, an intriguing, drought-resistant desmid recorded for the first time from continental Europe. - Biologia 58: 661-663.

Coesel, P.F.M., Meesters, J. \& Schulp, H.H.F. (2006): Subatmofytische sieralgsoorten, nieuw voor de 
Nederlandse flora. - Gorteria 31: 137-141.

Coesel, P.F.M. \& Meesters, J. (2007): Desmids of the Lowlands. Mesotaeniaceae and Desmidiaceae of the European Lowlands. - 351 pp., KNNV Publishing, Zeist, the Netherlands.

Coesel, P.F.M. \& Krienitz, L. (2008): Diversity and geographical distribution of desmids and other coccoid green algae. - Biodivers. Conserv. 17: 381-392.

Czurda, V. (1946): Die Reinkultur von Conjugaten. Arch. Protistenk. 53: 215-242.

ČERŇAJeV, V.P. (1931): Ein Beitrag zum Studium von Wachstumfaktoren an Karpfenbrut mit besonderer Berücksichtigung des Einflusses der Grössenverhältnisse des zur Verfügung stehenden Lebensraumes. - Zeitschr. f. Fischerei und deren Hilfswissenschaften 29: 217-282.

Dechant, E. (1914): Die Microorganismen der Budweiser Teiche. - Jahresber. der deutschen $\mathrm{k}$. k. Staats-Realschule Budweis: 3 - 24 .

DvořÁk, R. (1910): Př́spěvek ku květeně moravských řas. - Věst. Klubu prŕrodov. v Prostějově 13: 121-134.

DvořÁk, R. (1919): O výskytu Trentepohlií na vysočině Českomoravské. - Sborník klubu př́rodov. v Brně 2: 20-21.

DvořÁK, R. (1920): Sdělení o nových druzích moravských řas. - Published on authors own expenses in Třebíč.

DvoŘÁk, R. (1920-1921): Pátý příspěvek ku květeně moravských řas. - Věst. Klubu prírodov. v Prostějově 18: 24-49.

DvořÁk, R. (1932): Příspěvek ku poznání řas tůní a jejich rozšíření v oblasti západomoravské. Věda přírodní 13: 33-40.

DvořÁk, R. (1934): Př́ispěvek o rozšíření řas vodních toků oblasti západomoravské. - Př́roda 27: $10-16$.

FEHÉR, G. (2003): The desmid flora of some alkaline lakes and wetlands in Southern Hungary. Biologia 58: 671-683.

Fischer, R. (1920): Die Algen Mährens und ihre Verbreitung. - Verh. d. nat. Vereins in Brünn 57: 1-94.

FISCHER, R. (1922-1924): Ökologische Skizzen zur Algenflora des mährisch-schlesichen Gesenkes. - Verh. d. nat. Ver. in Brünn 59: 3-11.

FISCHER, R. (1924): Ökologische Skizzen zur Algenflora des mährisch - schlesischen Gesenkes. Schriften f. Süsswasser - u. Meereskunde, Heft. 7: $1-20$.

FÖRSTER, K. (1965): Beitrag zur Desmidieen-Flora der Torne-Lappmark in Schwedisch-Lappland. Ark. Bot. 6: 109-161.

Gessner, F. (1932): Der Moosebruch ein Hochmoor im Altvatergebirge. Ein Beitrag zur Kenntnis der Blänkenbiologie. - Arch. f. Hydrobiologie 23: 65-100.
Gontcharov, A. A. (1998): Desmids of lakes Chuhunenko and Zaria (Lazovsky Nature Reserve, Russia). - Algological Studies 90: 9-43.

Gontcharov, A.A. \& Watanabe, M.M. (1999): Rare and new desmids (Desmidiaceae, Chlorophyta) from Japan. - Phycological Research 47: 233240.

GRÖNBLAD, R. (1920): Finnländische Desmidaceen aus Keuru. - Acta Soc. Fauna Fl. Fenn. 47: 1-98.

GrönBlaD, R. (1921): New desmids from Finland and northern Russia with critical remarks on some known species. - Acta Soc. Fauna Fl. Fenn. 49: $1-78$.

GRÖNBLAD, R. \& RŮŽıčKA, J. (1959): Zur Systematik der Desmidiaceen. - Bot. Not. 112: 205-226.

Gutowski, A. \& Mollenhauer, D. (1996): Rote liste der Zieralgen (Desmidiales) Deutschlands, Schr. - R. f. Vegetationskunde 28: 679-708.

HÁJEK, M. \& VízDAL, P. (1998): Prostorová hydrologická struktura NPR Soos. - In: Lederer, F. \& ChocholoušKovÁ, Z. (eds): Flóra a vegetace minerálních pramenů a rašeliništ' NPR Soos. Sborník katedry biologie. - pp. 14-58, PeF ZČU, Plzeň.

HaŠLer, P., ŠTĚPÁNKovÁ, J., ŠPaČKovÁ, J., Neustupa, J., Kitner, M., Hekera, P., Veselá, J., Burian, J. \& PoulíčKovÁ, A. (2008): Epipelic cyanobacteria and algae: a case study from Czech ponds. Fottea 8: 133-146.

Holzer, O. (1931): Desmidiazeen im Gebiete von Bodenstadt. - Natur und Heimat 2: 53-54

InsAm, J. \& KRIEGER, W. (1936): Zur Verbreitung der Gattung Cosmarium in Südtirol. - Hedwigia 76: 95-113.

JAPP, G. (1930a): ̌̌asy v župě olomoucké. Seznam druhů. - Vlastvěda střední a severní Moravy. Vlastivědné příručky, sv. 1: 130-139.

JAPP, G. (1930b): Desmidiaceae okolí žd'árského. Čas. Vlast. spolku mus. v Olomouci 43: 30-36.

JÄRNEFELT, H. \& GRÖNBLAD, R. (1960): Neuer Fund von Cosmarium dilatatum nova species. - Schweiz. Z. Hydrol. 22: 150-151.

John, D.M. \& Williamson, D.B. (2009): A practical guide to the desmids of the West of Ireland. - 196 pp., Martin Ryan Institute, National University of Ireland, Galway.

Kitner, M., PoulíčKová, A., Novotný, M. \& Hájek, R. (2004): Desmids (Zygnematophyceae) of the spring fens of a part of West Carpathians. Czech Phycology 4: 43-61.

KomÁrek, J. \& RosA, K. (1957): Nález sinice Sommierella cossyrensis BoRzI (?) v Čechách. - Preslia 29:17-27.

Kotek, V. (1950): Zajímavé řasy z jižních Čech. - Čs. bot. Listy 2: 154-157.

Kouwets, F.A.C. (1984): The taxonomy, morphology and ecology of some smaller Euastrum species 
(Conjugatophyceae, Desmidiaceae). $-\mathrm{Br}$. Phycol. J. 19: 333-347.

Kouwets, F.A.C. (1987): Desmids from the Auvergne. - Hydrobiologia 146: 193-263.

Kouwets, F.A.C. (1988): Remarkable forms in the desmid flora of a small mountain bog in the French Jura. - Cryptogamie, Algologie 9: 289309.

Kouwets, F.A.C. (1991): Notes on the morphology and taxonomy of some rare or remarkable desmids (Chlorophyta, Zygnemaphyceae) from SouthWest France. - Nova Hedwigia 53: 383-408.

Kouwets, F.A.C. (1997): Contributions to the knowledge of the French desmid flora I. New and noteworthy taxa from the Central and Eastern Pyrenees. - Arch. Protistenk. 148: 3351.

Kouwets, F.A.C. (1998): Southern elements in the desmid flora of France. - Biologia 53: 445455.

Kouwets, F.A.C. (1999): A check-list of Desmids (Chlorophyta, Zygnemaphyceae) of France. - Patrimoines naturels (M.N.H.N./S.P.N.) 41: 150.

Kouwets, F.A.C. (2001): Contributions to the knowledge of the French desmid flora 3. New and rare taxa from the regions of Dordogne and Limousin. - Algological Studies 101: 27-55.

Kouwets, F.A.C. (2008): The species concepts in desmids: the problem of variability, infraspecific taxa and the monothetic species definition. Biologia 63: 877-883.

Krieger, W. (1937): Die Desmidiaceen Europas mit Berücksichtigung der aussereuropäischen Arten. - RABENHORST`s Kryptogamen - Flora von Deutschland, Österreich und der Schweiz 13, Abt. 1, Teil 1. - 712 pp., Akad. Verlagsges., Leipzig.

Krieger, W. \& Gerloff, J. (1965): Die Gattung Cosmarium. Lieferung 2. - pp. 113-240, J. Cramer, Weinheim.

LEDERER, F. (1998): Srovnání mikroflóry rašeliništ' Šumavy a Třeboňské pánve.- Ph.D. Thesis, University of Southern Bohemia, Faculty of Biological Sciences, České Budějovice.

Lederer, F., Gardavský, A., LukešovÁ, A., KubeČKovÁ, K., Č́́pová, R., Lodrová, E. \& TrojánKovÁ, K. (1998): Biodiverzita a ekologie sinic a řas minerálních pramenů a rašeliništ’ na území NPR Soos a v okolí Mariánských a Františkových Lázní. - In: Lederer, F. \& CHOCHOLOUŠKovÁ, Z. (eds): Flóra a vegetace minerálních pramenů a rašeliništ' NPR Soos. Sborník katedry biologie 14. - 58 pp., PeF ZČU, Plzeň.

Lederer, F. \& SoukupovÁ, L. (2002): Biodiversity and ecology of algae in mountain bogs (Bohemian Forest, Central Europe). - Algological Studies 106: $151-183$.
LenZenweger, R. (1986): Beitrag zur Kenntniss der Zieralgen der Nördlichen Kalkalpen Österreichs (Steiermark). - Algological Studies 42: 93122.

Lenzenweger, R. (1987): Beitrag zur Kenntniss der Zieralgenflora des Salzburger Lungaues. Algological Studies 46: 47-64.

LeNZENwEger, R. (1994): Die Desmidiaceenflora des Rosanin-Sees in den Nockbergen: (Salzburg, Österreich). - Nova Hedwigia 59: 163-187.

LENZENWEgER, R. (1996): Desmidiaceenflora von Österreich, Teil 1. - In: CRAMER, J. (ed.): Bibliotheca Phycologica 101. - 162 pp., Gebrüder Borntraeger Verlagsbuchhandlung, Berlin-Stuttgart.

LenZenweger, R. (1997): Desmidiaceenflora von Österreich, Teil 2. - In: CRAMER, J. (ed.): Bibliotheca Phycologica 102. - 216 pp., Gebrüder Borntraeger Verlagsbuchhandlung, Berlin-Stuttgart.

Lenzenweger, R. (1999): Desmidiaceenflora von Österreich, Teil 3. - In: CrAmER, J. (ed.): Bibliotheca Phycologica 104. - 218 pp., Gebrüder Borntraeger Verlagsbuchhandlung, Berlin-Stuttgart.

Lenzenweger, R. (2000a): Neue bemerkenswerte Zieralgenfunde aus Österreich.- Algological Studies 98: 27-41.

LenZENwEger, R.. (2000b): Vorläufiges Ergebnis der Untersuchungen zur Zieralgenflora der Schwemm bei Walchsee in Nordtirol (Desmidiaceae). - Ber. nat.-med. Verein Innsbruck 87: 41-66.

LENZENWEGER, R. (2002): Die Zieralgen (Desmidiaceae, Zygnematophyceae) einiger subalpiner Seen in den Niederen Tauern (Steiermark, Österreich). - Joannea Bot. 3: 9-16.

LENZENWEGER, R.(2003a): DieZieralgen(Desmidiaceae, Zygnemaphyceae) einiger alpiner Bergseen in Österreich (Niedere Tauern, Steiermark). Algological Studies 110: 27-41.

LENZENWEGER, R. (2003b): Desmidiaceenflora von Österreich, Teil 4. - In: CrAmer, J. (ed.): Bibliotheca Phycologica 111. - 87 pp., Gebrüder Borntraeger Verlagsbuchhandlung, Berlin-Stuttgart.

LenZenweger, R. \& Wertl, F. (2001): Zur Desmidiales (Chlorophyta) - Flora der Altwässer in den Donau - Auen bei Wien (Österreich). - Phyton 41: 247-267.

LhoтsкÝ, O. (1949): Poznámka k flóře Desmidiaceí Hrubého Jeseníku. - Čas. Vlast. spolku mus. v Olomouci 58: 149-155.

Lнотsкý, O. (1954): Několik zajímavých Desmidiaceí z Novozámeckého rybníka. - Ochrana př́rody 9: 115-119.

Lhotsкý, O. \& Rosa, K. (1955): Soupis moravskoslezských sinic a řas. - 260 pp., 
ČSAV, Praha.

LÜTKEMÜLLER, J. (1910): Zur Kenntniss der Desmidiaceen Böhmens. - Verh. zool. - bot. Ges. 60: 478-503.

MaLoch, F. (1937): Společenstva řas a rozsivek v jihozápadních Čechách. - Sborn. Prírodov. Klubu v Košiciach 3 (1935-1937): 37-72.

Marhold, K. \& HindÁK, F. (ed.) (1998): Zoznam nižších a vyšších rastlín Slovenska. (Checklist of non - vascular and vascular plants of Slovakia). - 688 pp., Veda, Bratislava.

Mattauch, F. (1936): Ein Beitrag zut Kenntnis der Verlandungserscheinungen am Hirschberger Grossteich. - Beih. Bot. Cbl. 54: 377 - 426.

Meesters, J. \& Coesel, P.F.M. (2007): Cosmarium denboeri: een nieuwe, planktonische sieralgsoort met een groot potentieel verspreidingsgebied. Gorteria 32: 144-147, 159.

MessiKommer, E. (1942): Beitrag zur Kenntnis der Algenflora und Algenvegetation des Hochgebirges um Davos. - Beitr. Geobot. Landesaufn. Schweiz 24: 1-452.

Nave, J. (1863): Algen Mährens und Schlesiens. Verh. D. naturf. Ver. In Brünn 2: 17-58.

Neustupa, J., Nováková, S., Šejnohová, L., ŠKaloud, P. \& ŘezÁČová, M. (2002): Algae from aquatic, peat bog, and aerial biotopes in the catchment area of the river Křemelná in Šumava National Park. - Czech Phycology 2: 47-60.

NoRdstedT, C.F.O. (1875): Desmidieae arctoae. Öfvers. Kongl. Svenska Vetens.-Akad. 1875: 13-43.

NovÁČEK, F. (1941): Fytoplankton a zooplankton rybníka „Hladu“ u Studence. - Práce Moravské př́rodov. spol. 13: 1-31.

NovákovÁ, M. \& PopovskÝ, J. (1972): Dicranochaete bohemica, sp. nova. - Arch. Protistenk. 114: $37-45$.

NovÁKovÁ, S. (2003): Ecological distribution patterns of desmid species in subalpine regions of the Krkonoše Mts. (Czech Republic). - Biologia 58: 697-700.

NovÁKovÁ, S. (2004): Spatial heterogenity of the algal flora in subalpine mires in the eastern Krkonoše Mts. (Giant Mountains, Czech Republic). Algological Studies 114: 23-37.

Pascher, A. (1903): Zur Algenflora des südlichen Böhmerwaldes. - Lotos 51-52: 161-211.

PAscher, A. (1906): Neuer Beitrag zur Algenflora des südlichen Böhmerwaldes. - Lotos 54: 147182.

PÉTERFI, L.S. (1974): Structure and pattern of desmid communities occuring in some Romanian ombrophilous peat bogs. - Nova Hedwigia 25: 651-664.

PoulíčKovÁ, A., Lhotský, O. \& Dř́imalová, D. (2004): Prodromus sinic a řas ČR. - Czech Phycology 4: 19-33.
RABENHORST, L. (1868): Flora europaea algarum aquae dulcis et submarinae, Sect. 3. - 461 pp., E. Kummerum, Leipzig.

Raciborski, M. (1889): Nowe Desmidyje. - Pam. Akad. Umiejetn. Kraków., Wydz. Matemat. Przyrod. 17: 73-113.

RIETH,A. (1982): Seltene oder bemerkenwerte Algen auf dem Gelände des Zentralinstituts. I. Spirotaenia bahusiensis NORDST. et LÜTKEM. 1895 (Chlorophyta, Zygnematales, Mesotaeniaceae). - Kulturpflanze 30: 293-298.

RosA, K. (1933): Př́íspěvek k řasové flóře rašelin u Jindřichova Hradce. - Čas. Nár. Musea, odd. př́rodov. 107: 130-135.

Rosa, K. (1939): Ein Beitrag zur Algenflora des Brdygebirges. - Studia Botanica Čechica 2: 158-180.

RosA, K. (1941): Die Algen des Schwarzen Sees und der Seewand im Böhmerwalde. - Studia Botanica Čechica 4: 1-16.

RosA, K. (1951): Algenflora von Südböhmen. I. Die Algen der Umgebung von Blatná.- Studia Botanica Čechoslovaca 12: 173-232.

RosA, K. (1968): Der Beitrag zur Algenflora in der Umgebung von České Budějovice (Böhmisch Budweis). - Sborn. Vys. Školy Zeměd. v Praze, Fak. agron. 1968: 29-35, 59-62.

RosA, K. (1969): Př́spěvek k výzkumu řasové flóry v okolí Vlašimi - II. - Sborník vlastivědných prací z Podblanicka, Benešov 10: 32-75.

Roubal, J. (1938): Flora desmidiaceí rašelinných jam u Př́ibraze. - Čas. Nár. Mus. 112: 83-95.

Roubal, J. (1939): Neue Arten und Varietäten von Desmidiaccen aus Südböhmen. - Studia Botanica Čechica 2: 107-116.

Roubal, J. (1958): Desmidiologické poznámky. Sborník Vyšší pedagog. školy v Plzni, Biologie - chemie 1: 71-124.

Roubal, J. (1959): Periodicita Desmidiaceí v rašelinné tůn̆ce u Borkovic. - Sborník Vyšší pedagog. školy v Plzni, Biologie - chemie 2: 100-171.

RƯŽǏčKA, J. (1949): Zajímavá Cosmaria z okolí Písku. Čas. Nár. musea, odd. přír. 117: 59-66.

RŮžıčKA, J. (1954): Krásivky (Desmidiaceae) řeky Moravice a jejích prítokủ. - Přírodov. sbor. Ostravského kraje 15: 290-303.

RưŽǏČKA, J. (1955a): Zajímavé krásivky (Desmidiales) Horní Oravy. - Biologia 10: 590-604.

RŮžıčKA, J. (1955b): Poznámky k systematice Desmidiaceí. 1.-4. - Preslia 27: 253-271.

RƯžıčKA, J. (1956): Krásivky pramenů Moravice (Velké Kotlina, Jeseníky). - Př́rodov. sbor. Ostravského kraje 17: 38-58.

RƯŽIČKA, J. (1957a): Krásivky Horní Vltavy. - Preslia 29: 132-154.

RǓŽıčKA, J. (1957b): Krásivky z prameništ' na Malém Dědu (Hrubý Jeseník). - Časopis Slezského musea 6: 108-121. 
RU゚ŽIČKA, J. (1967): Interessante Zieralgen aus der Hohen Tatra I. - Preslia 39: 244-259.

RŮŽIČKA, J. (1972): Die Zieralgen der Insel Hiddensee. - Arch. Protistenk. 114: 453-485.

RŮŽIČKA, J. (1973): Die Zieralgen des Naturschutzgebietes“"Řežabinec”(Südböhmen). - Preslia 45: 193-241.

RŮŽIČKA, J. (1977): Die Desmidiaceen Mitteleuropas, Band 1, 1. Lieferung. - 291 pp., E. Schweizerbart'sche Verlagsbuchhandlung, Stuttgart.

RŮŽIČKA, J. (1981): Die Desmidiaceen Mitteleuropas, Band 1, 2. Lieferung. - pp. 292-736, E. Schweizerbart'sche Verlagsbuchhandlung, Stuttgart.

RybníčeK, K. (1958): Krásivky pramenné oblasti Branné v Hrubém Jeseníku. - Př́rodov. sbor. Ostravského kraje 19: 97-122.

SCHARF, W. (1985): Vergleichende Betrachtungen zut Zieralgenflora der Eifelmaare. - Algological Studies 41: 549-602.

Schmidle, W. (1895): Beiträge zur alpinen Algenflora. - Österr. Bot. Zeitschr. 45: 387-391.

Skuja, H. (1929): Süsswasseralgen von den westestnischen Inseln Saaremaa und Hiiumaa. - Acta Horti Bot. Univ. Latv. 4: 1-76.

SkUJA, H. (1934): Beitrag zur Algenflora Lettlands. I. Acta Horti Bot. Univ. Latv. 7 (1932): 25-86.

SkujA, H. (1948): Taxonomie des Phytoplanktons einiger Seen in Uppland, Schweden. - Symbol. Bot. Upsaliensis 9: 1-399.

SládeČEK, V. (1950-1951): Limnologická studie o Padrt'ských rybnících. - Rozpravy II. tř. České akademie věd 60: 1-69.

Š́ejnohová, L., ŠKaloud, P., Neustupa, J., Nováková, S., ŘEzÁČOvÁ, M. \& OšLejŠKovÁ, L. (2003): Algae and cyanoprokaryotic species from peat bogs, streams, ponds and aerial biotopes in the region of South Šumava Mts. - Czech Phycology 3: 41-52.

ŠIMEK, O. (1992): Krásivky státní přírodní rezervace Řežabinec.- Dipl. Thesis, Charles University, Faculty of Science, Prague.

ŠIMEK, O. (1997): Changes in desmid flora of the nature reserve "Řežabinec" in Southern Bohemia after 30 years of intense environmental agriculture. Algological Studies 87: 59-85.

ŠKaloud, P. (2004): Aero-terestrické řasy vrcholových partií NPP Boreč. - Dipl. Thesis, Charles
University, Faculty of Science, Prague.

ŠKALOUD, P. (2009): Species composition and diversity of aero-terrestrial algae and cyanobacteria of the Boreč Hill ventracoles. - Fottea 9: 65-80.

ŠŤASTNÝ, J. (2005): Diverzita a ekologie krásivek ve vybraných oblastech České republiky. - Dipl. Thesis, Charles University, Faculty of Science, Prague.

ŠŤASTNÝ, J. (2008): Desmids from ephemeral pools and aerophytic habitats from the Czech Republic. Biologia 63: 884-890.

ŠŤAstnÝ, J. \& LENZENWEgER, R. (2008): Ein Nachtrag zur Zieralgenflora (Desmidiales, Zygnematophyceae) der Schwemm bei Walchsee in Nordtirol (Österreich). - Phyton (Horn, Austria) 48: 37-49.

ŠTĚPÁnKovÁ, J., VAVRuŠKovÁ, J., HaŠler, P., MAZAlovÁ, P. \& PoulíčKovÁ, A. (2008): Diversity and ecology of desmids of peat bogs in the Jizerské hory Mts. - Biologia 63: 891-896.

Tomaszewicz, G. H. \& Hindák, F. (2008): Some rare desmids (Zygnematophyceae) from Central Europe. - Biologia 63: 289-293.

West W. \& West, G.S. (1896): On some new and interesting freshwater algae. - J. Roy Microsc. Soc. 1896: 149-165.

West W. \& West, G.S. (1908): A monograph of the British Desmidiaceae, Vol III. - 274 pp., The Ray Society, London.

Williamson, D.B. (1997): Rare desmids from Scotland. - Algological Studies 84: 53-81.

Williamson, D.B. (2000): Some desmid floras of wet rock surfaces. - Algological Studies 97: 11-27.

Williamson, D.B. (2002): Rare desmids from garden ornaments and Scottish lochs. - Algological Studies 105: 79-86.

Williamson, D.B. (2003): Some desmids from the northern islands of Iceland and Orkney. - Nord. J. Bot. 22: 503-512.

Williamson, D.B. (2007): Actinotaenium infractum (Messik.) comb. nov. (Desmidiaceae) a new systematic position for Closterium infractum MEsSiKommer and a review of relevant literature. - Algological Studies 123: 47-55.

Wünsch, R. (1939): 7. Florenliste. - In: Geling, R. \& Wünsch, R. (eds): Die Pflanzendecke des Bezirkes Gablonz. - pp. 83-150, Heimatkunde für den Landeskreis Gablonz. 


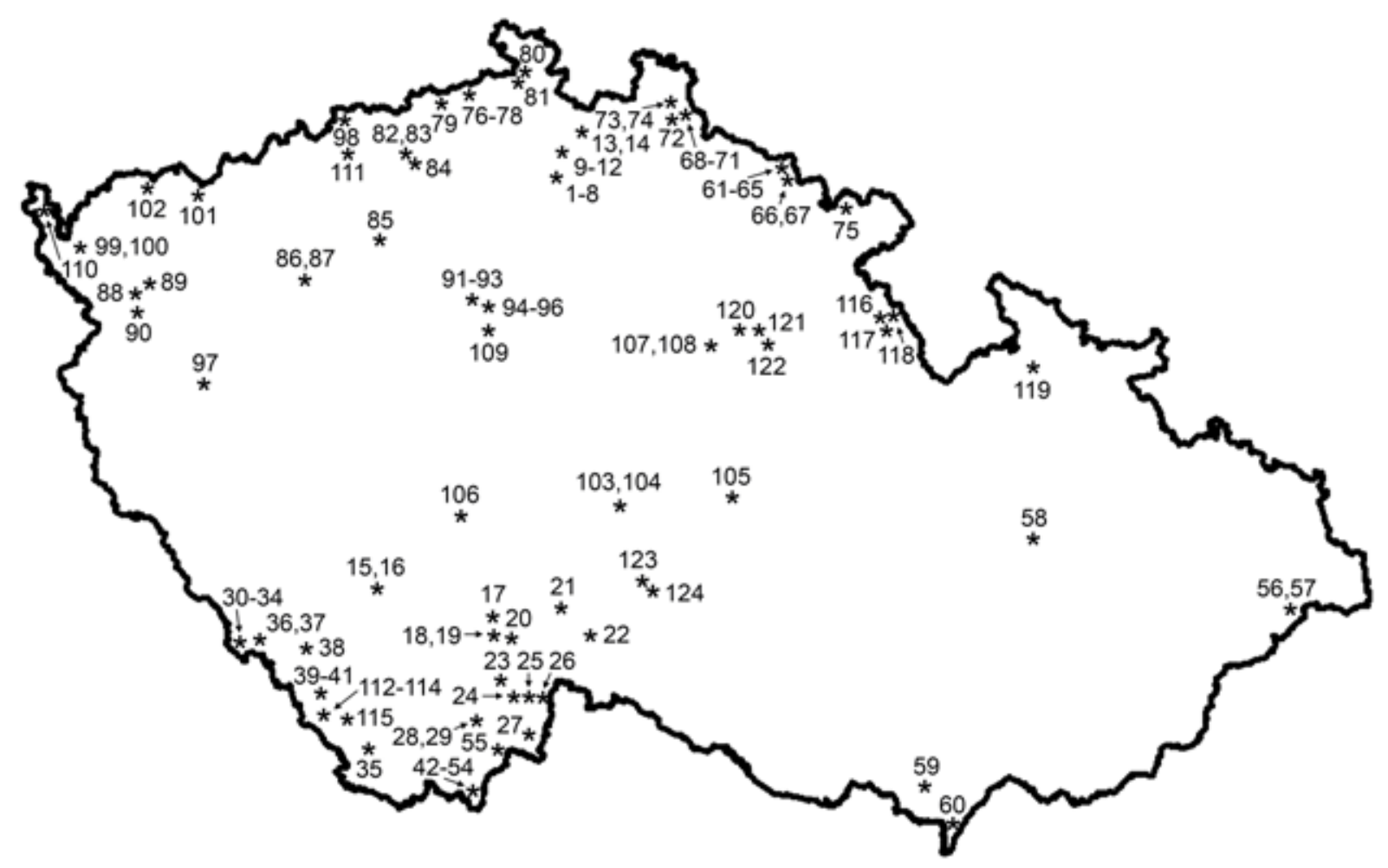

Fig. 1. Location of the sampling sites in the territory of the Czech Republic.

List of sampling sites

1. Nature reserve "Břehyně - Pecopala" - slightly eutrophic pond $\left(50^{\circ} 34^{\prime} 2.38^{\prime \prime} \mathrm{N}, 14^{\circ} 40^{\circ} 56.05^{\prime}\right.$ E; $\mathrm{pH}=7.5-7.7$, cond. $\left.=220-234 \mu \mathrm{S} . \mathrm{cm}^{-1}\right)$ surrounded with a large complex of bogs and fens ( $\mathrm{pH}$ at most sampling sites $=5.5-6.5$, cond. $=$ $\left.70-220 \mu \mathrm{S} . \mathrm{cm}^{-1}\right)$.

2. Máchovo jezero ( $\left.50^{\circ} 35^{\circ} 2.13^{\prime \prime} \mathrm{N}, 1^{\circ} 38^{\circ} 59.31^{\prime \prime} \mathrm{E}\right)$ - eutrophic pond; $\mathrm{pH}=7.5-8.0$, cond. $=212-276 \mu \mathrm{S} . \mathrm{cm}^{-1}$.

3. Nature reserve "Swamp" $\left(50^{\circ} 34^{\circ} 48.19^{\prime \prime} \mathrm{N}, 14^{\circ} 40^{\circ} 4.77^{\prime} \mathrm{E}\right)$ - transition bog; $\mathrm{pH}=3.5-5.4$, cond. $=88-174 \mu \mathrm{S} . \mathrm{cm}^{-1}$.

4. Unnamed transition bog about $350 \mathrm{~m}$ south-southeast from the "Swamp" Nature Reserve (50`34'34.44 " $\mathrm{N}, 14^{\circ} 40^{\circ}$ " $14.45^{\circ}$ " $\mathrm{E}) ; \mathrm{pH}=3.4-6.3$, cond. $=54-156 \mu \mathrm{S} . \mathrm{cm}^{-1}$.

5. Unnamed boggy pool on the southern side of "Máchovo jezero" fishpond (50`34‘39.25“ N, 14³9‘44.68“ $\mathrm{E})$; $\mathrm{pH}=$ 5.7-6.5, cond. $=198-307 \mu \mathrm{S} . \mathrm{cm}^{-1}$.

6. Unnamed transition bog on the northern side of "Máchovo jezero" fishpond $\left(50^{\circ} 35^{`} 38.69^{\prime \prime} \mathrm{N}, 14^{\circ} 38^{\circ} 37.01^{\text {" }} \mathrm{E}\right)$.

7. Ephemeral pool near "Břehyňský" pond $\left(50^{\circ} 34^{\prime} 32.27^{\prime \prime} \mathrm{N}, 14^{\circ} 40^{\circ} 49.55^{\prime \prime} \mathrm{E}\right) ; \mathrm{pH}=5.8$, cond. $=98 \mu \mathrm{S} . \mathrm{cm}^{-1}$.

8. Nature reserve "Mariánský rybník" (50³2‘43.59“ N, 1440‘42.71“ E) - oligomesotrophic boggy pond.

9. Držník $\left(50^{\circ} 36^{`} 39.32^{\prime \prime} \mathrm{N}, 14^{\circ} 43^{\prime} 23.26^{\prime \prime} \mathrm{E}\right)$ - mesotrophic pond (part of the "Hradčanské rybníky” Nature Reserve; $\mathrm{pH}$ $=6.0-6.1$, cond. $\left.=185-285 \mu \mathrm{S} . \mathrm{cm}^{-1}\right)$ with a neighboring transition bog; $\mathrm{pH}=5.5-5.8$, cond. $=120-168 \mu \mathrm{S} . \mathrm{cm}^{-1}$.

10. Strážovský rybník $\left(50^{\circ} 36^{`} 35.08^{\prime \prime} \mathrm{N}, 14^{\circ} 45^{`} 4.03^{\prime \prime} \mathrm{E}\right)$ - slightly eutrophic pond (part of the "Hradčanské rybníky" Nature Reserve); $\mathrm{pH}=6.1-6.6$, cond. $=334-362 \mu \mathrm{S} . \mathrm{cm}^{-1}$.

11. Hradčanský rybník $\left(50^{\circ} 37^{`} 1.55^{\prime \prime} \mathrm{N}, 14^{\circ} 42^{`} 38.55^{\prime \prime} \mathrm{E}\right)$ - slightly eutrophic pond; $\mathrm{pH}=6.4-6.6$, cond. $=225-265$ $\mu \mathrm{S} . \mathrm{cm}^{-1}$.

12. Hvězdovský rybník ( $\left.50^{\circ} 38^{\circ} 31.72^{\prime \prime} \mathrm{N}, 14^{\circ} 47^{\circ} 27.09^{\prime \prime} \mathrm{E}\right)$ - slightly eutrophic pond.

13. Nature reserve "Rašeliniště Černého rybníka” ( $\left.50^{\circ} 41^{\prime} 22.43^{\prime \prime} \mathrm{N}, 14^{\circ} 50^{\circ} 30.93^{\prime \prime} \mathrm{E}\right)$ - mesotrophic pond ( $\mathrm{pH}=6.7$, cond. $=96 \mu \mathrm{S} . \mathrm{cm}^{-1}$ ) with a neighboring transition bog.

14. Děvínský rybník (5041‘35.67“ N, 1451‘47.64“ E) - mesotrophic pond. Leg. Ladislav Hodač, Charles University, Prague.

15. Nature reserve "Řežabinec a Řežabinecké tůně” $\left(49^{\circ} 15^{\prime} 10.75^{\prime \prime} \mathrm{N}, 14^{\circ} 5\right.$ ‘31.99“ E) - eutrophic fishpond $(\mathrm{pH}=8.1-10.2$, cond. $\left.=312-499 \mu \mathrm{S} . \mathrm{cm}^{-1}\right)$ with neighboring pools $\left(\mathrm{pH}=6.1-7.4\right.$, cond. $\left.=396-827 \mu \mathrm{S} . \mathrm{cm}^{-1}\right)$.

16. Podkostelní rybník $\left(49^{\circ} 15^{\prime} 53.63^{\prime \prime} \mathrm{N}, 14^{\circ} 7^{`} 30.95^{\prime \prime} \mathrm{E}\right)$ - eutrophic fishpond; $\mathrm{pH}=7.7$, cond. $=357 \mu \mathrm{S} . \mathrm{cm}^{-1}$.

17. Nature reserve "Borkovická blata" $\left(49^{\circ} 14^{\circ} 9.36^{\prime \prime} \mathrm{N}, 14^{\circ} 37^{\circ} 24.84^{\prime \prime} \mathrm{E}\right)$ - transition bog; $\mathrm{pH}=5.5-6.5$, cond. $=60-160$ $\mu \mathrm{S} . \mathrm{cm}^{-1}$.

18. Oligotrophic, acidic pool in the "Ruda" Nature Reserve $\left(49^{\circ} 9^{\prime} 8.29^{\prime \prime} \mathrm{N}, 14^{\circ} 41^{\prime} 30.66^{\prime \prime} \mathrm{E}\right)$.

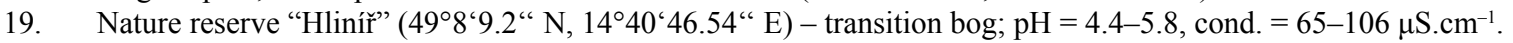

20. Nature reserve "Rod" ( $\left.49^{\circ} 7^{\prime} 15.94^{\prime \prime} \mathrm{N}, 14^{\circ} 44^{\prime} 59.42^{\prime \prime} \mathrm{E}\right)$ - transition bog; $\mathrm{pH}=5.5-6.2$, cond. $=116-178 \mu \mathrm{S} . \mathrm{cm}^{-1}$.

21. Nature reserve "Luží u Lovětína" $\left(49^{\circ} 12^{`} 20.77^{\prime \prime} \mathrm{N}, 15^{\circ} 3^{`} 18.68^{\prime \prime} \mathrm{E}\right)$ - complex of several mesotrophic and slightly eutrophic pools.

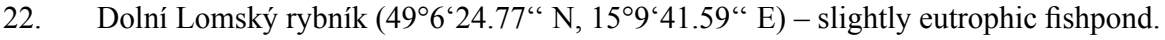

23. Nature reserve "V Rájích" $\left(48^{\circ} 59^{`} 10.35^{\prime \prime} \mathrm{N}, 14^{\circ} 42^{`} 31.63^{\prime \prime} \mathrm{E}\right)$ - mesotrophic spring area; $\mathrm{pH}=5,9-7,2$, cond. = 233- 
$330 \mu \mathrm{S} . \mathrm{cm}^{-1}$.

24. Pískovny Cep (48 $55^{\circ} 24.19^{\prime \prime} \mathrm{N}, 14^{\circ} 50^{`} 19.34^{\prime}$ E) - complex of several oligotrophic and mesotrophic pools; $\mathrm{pH}=$ $4,3-7,0$, cond. $=22-50 \mu \mathrm{S} . \mathrm{cm}^{-1}$.

25. Nature reserve "Vizír" $\left(48^{\circ} 57^{`} 46.87^{\prime \prime} \mathrm{N}, 14^{\circ} 53^{`} 13.01\right.$ “ E) - slightly eutrophic pond ( $\mathrm{pH}=6,5-7,5$, cond. $=110-185$ $\left.\mu \mathrm{S} . \mathrm{cm}^{-1}\right)$ with a neighboring transition bog $\left(\mathrm{pH}=4,0-5,5\right.$, cond. $\left.=95-131 \mu \mathrm{S} . \mathrm{cm}^{-1}\right)$.

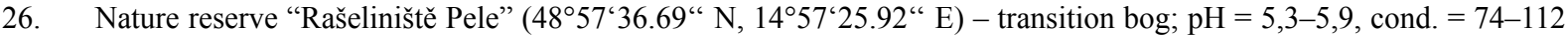
$\mu \mathrm{S} . \mathrm{cm}^{-1}$.

27. Eutrophic pool in the "Horní Lužnice" Nature Reserve $\left(48^{\circ} 51\right.$ ‘ $3.72^{\prime \prime} \mathrm{N}, 14^{\circ} 54^{`} 28.76^{\prime \prime}$ E); pH $=7.8$, cond. $=212$ $\mu \mathrm{S} . \mathrm{cm}^{-1}$

28. Krčín (48 $53^{\circ}$ ‘55.42“ N, 1439‘53.04“ E) - eutrophic fishpond.

29. Nature reserve "Žemlička” $\left(48^{\circ} 53^{\prime} 29.09^{\prime \prime} \mathrm{N}, 14^{\circ} 41^{\prime} 21.74^{\prime \prime} \mathrm{E}\right)$ - mesotrophic pond with a neighboring spring fen ( $\mathrm{pH}$ $=6.3-6.8$, cond.$\left.=139-241 \mu \mathrm{S} . \mathrm{cm}^{-1}\right)$.

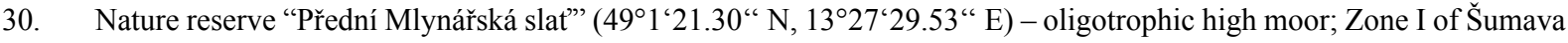
National Park; $\mathrm{pH}=3.7-4.1$, cond. $=37-93 \mu \mathrm{S} . \mathrm{cm}^{-1}$.

31. Shallow pool near the way from Přední Mlynářská slat' to the "Roklanský" stream $\left(49^{\circ} 1^{\prime} 20.31^{\prime \prime} \mathrm{N}, 13^{\circ} 27^{`} 9.67^{\prime \prime} \mathrm{E}\right)$; Zone I of Šumava National Park; $\mathrm{pH}=5.8$, cond. $=27 \mu \mathrm{S} . \mathrm{cm}^{-1}$.

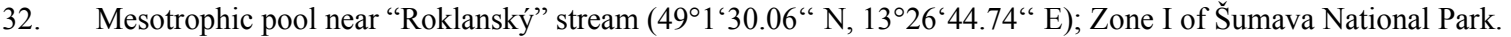

33. Mesotrophic ditch near "Roklanský” stream ( $49^{\circ} 1^{\prime} 42.71^{\prime \prime} \mathrm{N}, 13^{\circ} 26^{\circ} 49.47^{\prime \prime}$ E); Zone I of Šumava National Park.

34. Shallow, water-filled ditch near the way from Novohut'ské močály to the "Březník" mountain (4858‘18.90“ N, $13^{\circ} 28^{\prime} 3.80^{\prime \prime} \mathrm{E}$; Šumava National Park); $\mathrm{pH}=5.3$, cond. $=17 \mu \mathrm{S} . \mathrm{cm}^{-1}$.

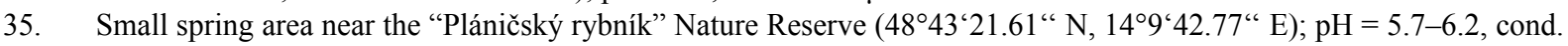
$=96-115 \mu \mathrm{S} . \mathrm{cm}^{-1}$.

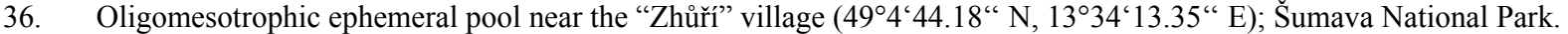

37. Oligomesotrophic ephemeral pool near the "Olšinka” stream $\left(49^{\circ} 1^{\prime} 15.28^{\prime \prime} \mathrm{N}, 13^{\circ} 36^{`} 38.59^{\prime \prime} \mathrm{E}\right)$; Šumava National Park.

38. Oligomesotrophic ephemeral pool near the "Solovec" mountain ( $\left.48^{\circ} 58^{‘} 34.79^{\prime \prime} \mathrm{N}, 13^{\circ} 51^{\prime} 16.33^{\prime \prime} \mathrm{E}\right)$; Šmava Protected Landscape Area.

39. Oligomesotrophic ephemeral ditch near the "Spáleniště” mountain ( $48^{\circ} 52^{\prime} 31.36^{\prime \prime} \mathrm{N}, 13^{\circ} 48^{‘} 7.95^{\prime \prime}$ E); Sumava National Park.

40. Mesotrophic ephemeral ditch near the "Pěkná” village ( $48^{\circ} 51^{`} 44.32^{\prime \prime}$ N, $13^{\circ} 57^{\prime} 5.03^{\prime \prime}$ E); Šumava Protected Landcape Area.

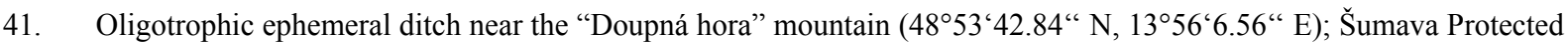
Landscape Area.

42. Mlýnský rybník ( $48^{\circ} 42^{`} 38.67^{\prime \prime} \mathrm{N}, 14^{\circ} 42^{`} 43.19^{\prime}$ E) - mesotrophic pond; Novohradské hory Mts Protected Landcape Area; $\mathrm{pH}=5.8-6.7$, cond. $=49-108 \mu \mathrm{S} . \mathrm{cm}^{-1}$.

43. Oligomesotrophic ephemeral pool near the "Mlýnský" pond (4842’33.09” N, 1442’47.09" E); Novohradské hory Mts Protected Landcape Area; $\mathrm{pH}=5.6$, cond. $=13 \mu \mathrm{S} . \mathrm{cm}^{-1}$.

44. Zlatá Ktiš $\left(48^{\circ} 40^{\prime} 44.03\right.$ ” N, 14²'35.92” E) - mesotrophic pond; Novohradské hory Mts Protected Landscape Area; $\mathrm{pH}=6.1-6.9$, cond. $=53-81 \mu \mathrm{S} . \mathrm{cm}^{-1}$.

45. Oligomesotrophic ephemeral pool near the "Zlatá Ktiš” pond (4840‘48.09“ N, 1442‘32.57“ E); Novohradské hory Mts Protected Landscape Area.

46. Small mesotrophic pond near the “Žofín” village (4840’32.99” N, 1441’33.61” E); Novohradské hory Mts Protected Landscape Area; $\mathrm{pH}=6.5$ cond. $=104 \mu \mathrm{S} . \mathrm{cm}^{-1}$.

47. Hut'ský rybník (48³9’20.99” N, 1440’56.36” E) - mesotrophic pond; Novohradské hory Mts Protected Landscape Area; $\mathrm{pH}=5.6-6.4$, cond. $=32-69 \mu \mathrm{S} . \mathrm{cm}^{-1}$.

48. Uhlišt'ský rybník (48`38‘48.01“ N, 14³9‘20.55“ E) - mesotrophic pond; Novohradské hory Mts Protected Landscape Area; $\mathrm{pH}=5.5-6.2$, cond. $=36-43 \mu \mathrm{S} . \mathrm{cm}^{-1}$.

49. Pohořský rybník (4837‘4.27“ N, 1440`26.86“ E) - mesotrophic pond; Novohradské hory Mts Protected Landscape Area; $\mathrm{pH}=5.1-6.2$, cond. $=23-40 \mu \mathrm{S} . \mathrm{cm}^{-1}$.

50. Wet mosses on the margin of "Pohořský" pond (48³7‘3.29“ N, 1440`25.81“ E); Novohradské hory Mts Protected Landscape Area.

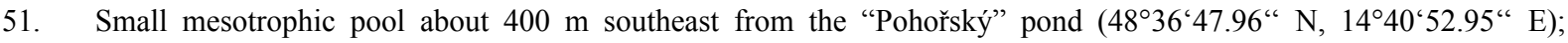
Novohradské hory Mts Protected Landscape Area; $\mathrm{pH}=7.0$, cond. $=47 \mu \mathrm{S} . \mathrm{cm}^{-1}$.

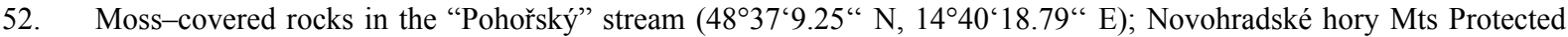
Landscape Area.

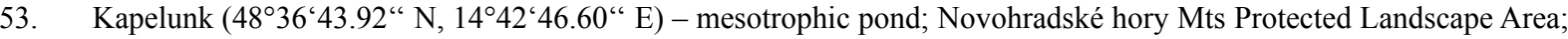
$\mathrm{pH}=6.3-6.7$, cond. $=34-86 \mu \mathrm{S} . \mathrm{cm}^{-1}$.

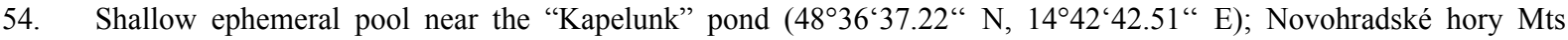
Protected Landscape Area; $\mathrm{pH}=6.2$, cond. $=39 \mu \mathrm{S} . \mathrm{cm}^{-1}$.

55. Nature reserve "Přesličkový rybník" $\left(48^{\circ} 46^{`} 15.63^{\prime \prime} \mathrm{N}, 14^{\circ} 48^{\circ} 11.14\right.$ " E) - mesotrophic pond; $\mathrm{pH}=5.9$, cond. $=60$ $\mu \mathrm{S} . \mathrm{cm}^{-1}$.

56. Oligomesotrophic ephemeral pool near the "Gruň" mountain $\left(49^{\circ} 29^{‘} 32.51^{\prime \prime}\right.$ N, $18^{\circ} 30^{\prime} 22.63^{\prime \prime}$ E); Beskydy Protected Landscape Area; $\mathrm{pH}=5.9$, cond. $=80 \mu \mathrm{S} . \mathrm{cm}^{-1}$.

57. Mesotrophic ephemeral ditch (49 $\left.30^{\circ} 41.83^{\prime \prime} \mathrm{N}, 18^{\circ} 28^{\prime} 37.53^{\prime \prime} \mathrm{E}\right)$ near the "Okrouhlice” mountain; Beskydy Protected Landscape Area. 
58. Slightly eutrophic pool near the "Chomoutovské jezero" Nature Reserve (49³8‘46.54" N, 17¹4‘35.12" E); $\mathrm{pH}=$ 7.9-8.1. Leg. Ludmila Hájková, Masaryk University, Brno.

59. Nature reserve "Zámecký rybník” $\left(48^{\circ} 48^{`} 29.93^{\prime \prime} \mathrm{N}, 16^{\circ} 48^{` 34.02 “ ~ E) ~-~ e u t r o p h i c ~ f i s h p o n d ; ~} \mathrm{pH}=8.4\right.$, cond. $=528$ $\mu \mathrm{S} . \mathrm{cm}^{-1}$.

60. Eutrophic ditch near the "Ranšpurk" Nature Reserve (48 40 ‘53.78“ N, $16^{\circ} 58^{\circ} 5.40^{\circ}$ “ E).

61. Wet, moss covered granite rocks in the "Pančavský" waterfall $\left(50^{\circ} 45^{\prime} 39.75^{\prime \prime} \mathrm{N}, 15^{\circ} 32^{\circ} 42.64^{\prime \prime} \mathrm{E}\right)$; Zone I of the Krkonoše Mts National Park; $\mathrm{pH}=7.0$, cond. $=13 \mu \mathrm{S} . \mathrm{cm}^{-1}$.

62. Wet, sometimes moss-covered granite rocks in the "Úpský” waterfall (5043‘56.018“ N, 1542‘44.678“ E), Zone I of the Krkonoše Mts National Park; $\mathrm{pH}=5.6$, cond. $=12 \mu \mathrm{S} . \mathrm{cm}^{-1}$.

63. Wet, moss-covered granite rocks in the "Zelený” stream $\left(50^{\circ} 42^{\prime} 8.25^{\prime \prime} \mathrm{N}, 15^{\circ} 41^{\prime} 54.28^{\prime \prime} \mathrm{E}\right)$; Krkonoše Mts National Park; $\mathrm{pH}=6.6$, cond. $=14 \mu \mathrm{S} . \mathrm{cm}^{-1}$.

64. The "Úpa" river near the town of Pec pod Sněžkou $\left(50^{\circ} 43^{\prime} 0.41^{\prime \prime}\right.$ N, $15^{\circ} 43^{\prime} 25.68^{\prime \prime}$ E); Krkonoše Mts National Park; $\mathrm{pH}=6.2$, cond. $=32 \mu \mathrm{S} . \mathrm{cm}^{-1}$.

65. Small peat bog near the locality no. $64\left(50^{\circ} 43^{`} 0.51^{\prime \prime} \mathrm{N}, 15^{\circ} 43^{`} 25.09^{\prime \prime} \mathrm{E}\right)$; Krkonoše Mts National Park; $\mathrm{pH}=5.1$, cond. $=14 \mu \mathrm{S} . \mathrm{cm}^{-1}$.

66. Ephemeral pool near the “Černohorské rašeliniště” peat bog $\left(50^{\circ} 40^{`} 31.574\right.$ “ N, 1543‘29.858“ E); Krkonoše Mts National Park; $\mathrm{pH}=5.7$, cond. $=119 \mu \mathrm{S} . \mathrm{cm}^{-1}$

67. Ephemeral pond near the town of Pec pod Sněžkou (5040’51.29” N, 1543’33.93” E); Krkonoše Mts National Park

68. Nature reserve "Na Čihadle" (5049‘ $\left.57.73^{\prime \prime} \mathrm{N}, 15^{\circ} 13^{\prime} 51.68^{\prime \prime} \mathrm{E}\right)$ - oligotrophic high moor, Jizerské hory Mts Protected Landscape Area; $\mathrm{pH}=4.3-4.4$, cond. $=28-35 \mu \mathrm{S} . \mathrm{cm}^{-1}$.

69. Klugeho louka - part of the "Rašeliniště Jizerky” Nature Reserve (5049‘45.37“ N, $15^{\circ} 20^{\circ} 9.86^{\circ}$ “ E) - oligotrophic high moor, Jizerské hory Mts Protected Landscape Area; $\mathrm{pH}=4.3-4.6$, cond. $=35-52 \mu \mathrm{S} . \mathrm{cm}^{-1}$.

70. Vyhlídková louka - part of the "Rašeliniště Jizerky" Nature Reserve $\left(50^{\circ} 49\right.$ ‘39.06“ N $15^{\circ} 19^{\circ} 40.45^{\prime \prime}$ E) - oligotrophic high moor, Jizerské hory Mts Protected Landscape Area; $\mathrm{pH}=4.5-4.7$, cond. $=32-44 \mu \mathrm{S} . \mathrm{cm}^{-1}$.

71. Tetřeví louka - part of the "Černá jezírka” Nature Reserve (5050‘44.92“ N, 15¹8‘11.04“ E) - oligotrophic high moor, Jizerské hory Mts Protected Landscape Area; $\mathrm{pH}=4.1-4.5$, cond. $=28-40 \mu \mathrm{S} . \mathrm{cm}^{-1}$.

72. Oligotrophic ephemeral pool near the "Josefüv důl” water reservoir $\left(50^{\circ} 47^{\prime} 41.90^{\prime \prime}\right.$ N, $15^{\circ} 11$ '49.60" E); Jizerské hory Mts Protected Landcape Area; $\mathrm{pH}=4.9$, cond. $=35 \mu \mathrm{S} . \mathrm{cm}^{-1}$.

73. Wet, moss-covered rocks in the "Sloupský" stream, near the "Štolpišský" waterfall (50॰51'4.06" N, 15¹1'39.40" E); Jizerské hory Mts Protected Landscape Area.

74. Mucilaginous growths on granite rocks near locality no. $73\left(50^{\circ} 51^{\prime} 1.75^{\prime \prime} \mathrm{N}, 15^{\circ} 11^{\prime} 31.41^{\prime}\right.$ ' E); Jizerské hory Mts Protected Landscape Area.

75. Ephemeral pool in the "Adršpašsko-Teplické skály” Nature Reserve (50³6’39.48” N, 166’35.14” E).

76. Nature reserve "Rybník u Králova mlýna" (5050’1.25” N, 149’20.38” E) - mesotrophic fishpond; Labské pískovce Protected Landscape Area; $\mathrm{pH}=6.3-6.6$, cond. $=264-286 \mu \mathrm{S} . \mathrm{cm}^{-1}$.

77. Fire pond near the "Maxičky" village (5048‘29.04“ N, 14¹0‘54.96“ E); Labské pískovce Protected Landscape Area; $\mathrm{pH}=6.5$, cond. $=215 \mu \mathrm{S} . \mathrm{cm}^{-1}$.

78. Wet rocks in an unnamed forest stream (5049`1.28“ N, $14^{\circ} 10^{`} 1.63^{\circ}$ “ E); Labské pískovce Protected Landscape Area; $\mathrm{pH}=6.0$, cond. $=244 \mu \mathrm{S} . \mathrm{cm}^{-1}$.

79. Mesotrophic pond near the "Libouchec" village $\left(50^{\circ} 45^{`} 59.37^{\prime \prime} \mathrm{N}, 14^{\circ} 3^{`} 32.01^{\prime \prime}\right.$ E), part of the "Libouchecké rybníčky" Nature Reserve; $\mathrm{pH}=6.6$, cond $=118 \mu \mathrm{S} . \mathrm{cm}^{-1}$. Leg. Sylvie Odstrčilová, Charles University, Prague.

80. Vlčí potok $\left(50^{\circ} 55^{\prime} 50.25^{\prime \prime} \mathrm{N}, 14^{\circ} 25^{\prime} 52.93^{\prime \prime} \mathrm{E}\right)$ - periodically desiccating stream; National Park Bohemian Switzerland; $\mathrm{pH}=6.9-7.3$, cond. $=152-162 \mu \mathrm{S} . \mathrm{cm}^{-1}$. Leg. Jana Veselá, Charles University, Prague.

81. Wet sandstone rocks in the National Park Bohemian Switzerland (5053‘20.99“ N, 14²2‘16.91“ E). Leg. Marie Pažoutová, Charles University, Prague.

82. Rašeliniště pod Bukovým vrchem (50³2'54.41" N, 1354'18.37" E) - mesotrophic peat bog, part of the "Březina" Nature Reserve.

83. Vojenský rybník (50³2‘47.13“ N, $13^{\circ} 53^{\circ} 47.79^{\circ}$ “ E) - mesotrophic pond; České středohoří Protected Landscape Area.

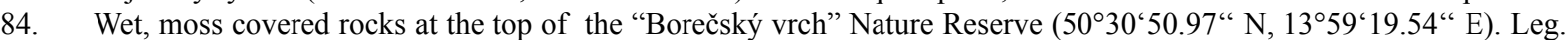
Pavel Škaloud, Charles University, Prague.

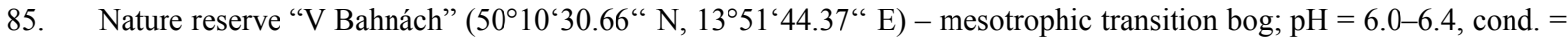
$132-211 \mu \mathrm{S} . \mathrm{cm}^{-1}$.

86. Nature reserve "Rybníčky u Podbořánek” $\left(50^{\circ} 2^{`} 34.87^{\prime \prime}\right.$ N, $13^{\circ} 26^{`} 27.69^{\prime \prime}$ E) - two mesotrophic ponds; pH = 6.9-7.5, cond $=190-207 \mu \mathrm{S} . \mathrm{cm}^{-1}$.

87. Oligomesotrophic ephemeral pool near the locality no. $86\left(50^{\circ} 2^{`} 35.11^{\prime \prime} \mathrm{N}, 13^{\circ} 26^{`} 23.49^{\prime \prime} \mathrm{E}\right)$.

88. Kladský rybník ( $50^{\circ} 1 ` 35.88^{\prime}$ “ N, $12^{\circ} 40^{`} 31.20^{\prime}$ E) - mesotrophic pond; Slavkovský les Protected Landscape Area; $\mathrm{pH}$ = 5.8. Leg. Ladislav Hodač, Charles University, Prague.

89. Mesotrophic pool in the "Upolínová louka” Nature Reserve (50³‘59.74“ N, 1244‘43.44“ E); Slavkovský les Protected Landscape Area. Leg. Ladislav Hodač, Charles University, Prague.

90. Mucilaginous growths on the concrete wall of an artificial pool in the town of Mariánské Lázně (49 $57^{\circ}$ ‘30.38“ N, $12^{\circ} 41^{\prime} 52.41^{\prime \prime}$ E). Leg. Ladislav Hodač, Charles University, Prague.

91. Periodically desiccating concrete drainage gutter near the railway corridor in the town of Roztoky u Prahy $\left(50^{\circ} 9^{`} 9.57^{\prime}\right.$ “ $\left.\mathrm{N}, 14^{\circ} 23^{\prime} 50.50^{\prime \prime} \mathrm{E}\right) ; \mathrm{pH}=7.9$, cond. $=175 \mu \mathrm{S} . \mathrm{cm}^{-1}$.

92. Periodically desiccating concrete drainage gutter near the railway corridor in the town of Roztoky u Prahy-Žalov $\left(50^{\circ} 10^{\prime} 4.53^{\prime \prime} \mathrm{N}, 14^{\circ} 21^{\prime} 52.07^{\prime \prime} \mathrm{E}\right)$. 
93. Periodically desiccating concrete drainage gutter near the railway station Praha-Sedlec $\left(50^{\circ} 77^{\prime} 52.84^{\prime \prime}\right.$ N, $14^{\circ} 23^{\prime} 50.88^{\prime}$ " E).

94. Periodically desiccating concrete drainage gutter near the railway station Praha-Liben (506'2.19” N, 14³0'5.37' E); $\mathrm{pH}=7.2$, cond. $=129 \mu \mathrm{S} . \mathrm{cm}^{-1}$.

95. Periodically desiccating concrete drainage gutter near the railway station Praha-Běchovice $\left(50^{\circ} 4^{\prime} 56.17^{\prime}\right.$ ' N, $\left.14^{\circ} 35^{\prime} 34.49^{\prime \prime} \mathrm{E}\right)$

96. Hostivař $\left(50^{\circ} 2^{\prime} 31.07^{\prime \prime} \mathrm{N}, 14^{\circ} 32^{\prime} 6.21^{\prime}\right.$ ' E) - eutrophic water reservoir

97. Hracholusky $\left(49^{\circ} 47^{\prime} 35.19^{\prime}\right.$ N, $13^{\circ} 8^{\prime} 39.81^{\prime}$ E) - eutrophic water reservoir.

98. Fláje $\left(50^{\circ} 41^{`} 3.30^{\prime \prime} \mathrm{N}, 13^{\circ} 35^{\circ} 6.43^{\prime \prime} \mathrm{E}\right)$ - mesotrophic water reservoir; $\mathrm{pH}=7.0$, cond. $=71 \mu \mathrm{S} . \mathrm{cm}^{-1}$.

99. Peat bog near the "Kateřina” village $\left(50^{\circ} 9^{\prime} 20.33^{\prime}\right.$ ” N, $12^{\circ} 24^{\prime} 33.37$ ” E); part of the „Soos“ Nature Reserve; $\mathrm{pH}=$ 5.0-6.2, cond. $=65-126 \mu \mathrm{S} . \mathrm{cm}^{-1}$.

100. Ephemeral pool near the locality no $99 .\left(50^{\circ} 9{ }^{\prime} 21.77^{\prime \prime} \mathrm{N}, 12^{\circ} 24^{\prime} 29.45^{\prime \prime} \mathrm{E}\right)$.

101. Shallow, oligomesotrophic pool on the margin of the "Božídarské rašeliniště" Nature Reserve $\left(50^{\circ} 24\right.$ '24.08" N, $\left.12^{\circ} 54^{\prime} 45.18^{\prime \prime} \mathrm{E}\right) ; \mathrm{pH}=5.4$, cond. $=111 \mu \mathrm{S} . \mathrm{cm}^{-1}$.

102. Nature reserve "Velký močál" $\left(50^{\circ} 23^{\prime} 41.74 " \mathrm{~N}, 12^{\circ} 38^{\prime} 17.23\right.$ ” E) - oligotrophic high moor; $\mathrm{pH}=3.9$, cond. $=80$ $\mu \mathrm{S} . \mathrm{cm}^{-1}$. Leg. Jiří Neustupa, Charles University, Prague.

103. Nature reserve "Chvojnov" (49²4'23.39" N, 15²5'10.24” E) - mesotrophic spring fen.

104. Desiccating mesotrophic pool in the "Na Oklice" Nature Reserve (49²4'12.93” N, 15²3'39.03” E).

105. Shallow mesotrophic pool near the "Babín" fishpond (49³2’37.67” N, 1553’50.73” E). Leg. Helena Bestová, Charles University, Prague.

106. Small eutrophic pond near the "Malšice" village (49²1’31.49” N, $14^{\circ} 34^{\prime} 9.11$ ” E).

107. Wet soil and mosses on a concrete platform near the railway station Chvaletice $\left(50^{\circ} 2{ }^{\prime} 14.52^{\prime \prime} \mathrm{N}, 15^{\circ} 25^{\prime} 6.13^{\prime \prime} \mathrm{E}\right)$.

108. The Labe river near the town of Chvaletice $\left(50^{\circ} 2 ' 26.07^{\prime \prime} \mathrm{N}, 15^{\circ} 21^{\prime} 24.18^{\prime \prime} \mathrm{E}\right)$.

109. The Sázava river near the town of Pikovice $\left(49^{\circ} 52^{\prime} 42.43^{\prime \prime} \mathrm{N}, 14^{\circ} 25^{\prime} 39.25^{\prime \prime} \mathrm{E}\right)$.

110. Wet, moss covered rocks in the "Bílý Halštrov" stream near the "Dolní Paseky" village $\left(50^{\circ} 14\right.$ '14.02" N, 12¹4’3.01" E).

111. Squeezed mosses from a concrete platform near the inflow of "Mračný potok" stream into the Bílina river (50³2’36.84" $\left.\mathrm{N}, 13^{\circ} 36^{\prime} 58.34^{\prime \prime} \mathrm{E}\right)$.

112. Wet, moss covered rocks in the "Kobylí smyk" stream (4846’36.36" N, 1354'13.68" E); Šumava National Park.

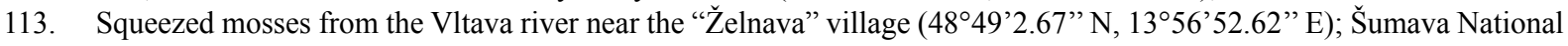
Park.

114. The "Lipno I" water reservoir near the "Nová Pec" village (4847’36.03” N, 1357’5.31" E); Sumava National Park.

115. Squeezed mosses from a concrete drainage gutter in the town of Horní Planá (4845'48.98 " N, $14^{\circ} 1^{\prime}$ '41.02" E); Šumava Protected Landscape Area.

116. Oligomesotrophic ephemeral pool near the town of Deštné v Orlických horách $\left(50^{\circ} 17^{`} 45.44^{“} \mathrm{~N}, 16^{\circ} 20^{‘ 3} 32.79^{\prime \prime E}\right)$; Orlické hory Protected Landscape Area.

117. Oligomesotrophic ephemeral pool near the "Karlův vrch" mountain $\left(50^{\circ} 16^{\prime} 14.89^{\prime}{ }^{\prime}, 16^{\circ} 22\right.$ '16.97”E); Orlické hory Protected Landscape Area.

118. Nature reserve "Velká louka" $\left(50^{\circ} 19^{\prime} 8.83^{\prime} \mathrm{N}, 16^{\circ} 25^{\prime} 28.46\right.$ ”E) - oligomesotrophic spring area with some mesotrophic, artificial pools; Orlické hory Protected Landscape Area.

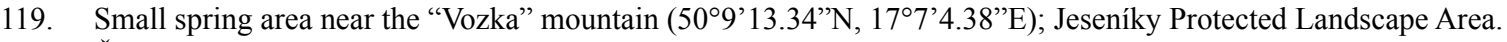

120. Černý Nadýmač (504‘25.99“N, 15³4‘54.08“E) - mesoeutrophic pond.

121. Mesoeutrophic sandy pool near the town of Lázně Bohdaneč $\left(50^{\circ} 4^{\circ} 14.16^{\prime \prime} \mathrm{N}, 15^{\circ} 41^{\circ} 47.42^{\prime \prime} \mathrm{E}\right)$ filled in with Utricularia australis R.BR.

122. Mesoeutrophic pool in the town of Pardubice $\left(50^{\circ} 2^{\circ} 43.32^{\prime \prime} \mathrm{N}, 15^{\circ} 46^{\circ} 57.18^{\prime \prime} \mathrm{E}\right)$ filled in with Ceratophyllum demersum L.

123. Nature reserve "Velký Pařezitý rybník" (49¹3’43.59”N, 15²2’32.048”E) - oligomesotrophic pond with a neighboring transition bog.

124. S Štěpnický rybník (49॰11‘6.961“N, 15²7‘26.093“E) - eutrophic fishpond. 


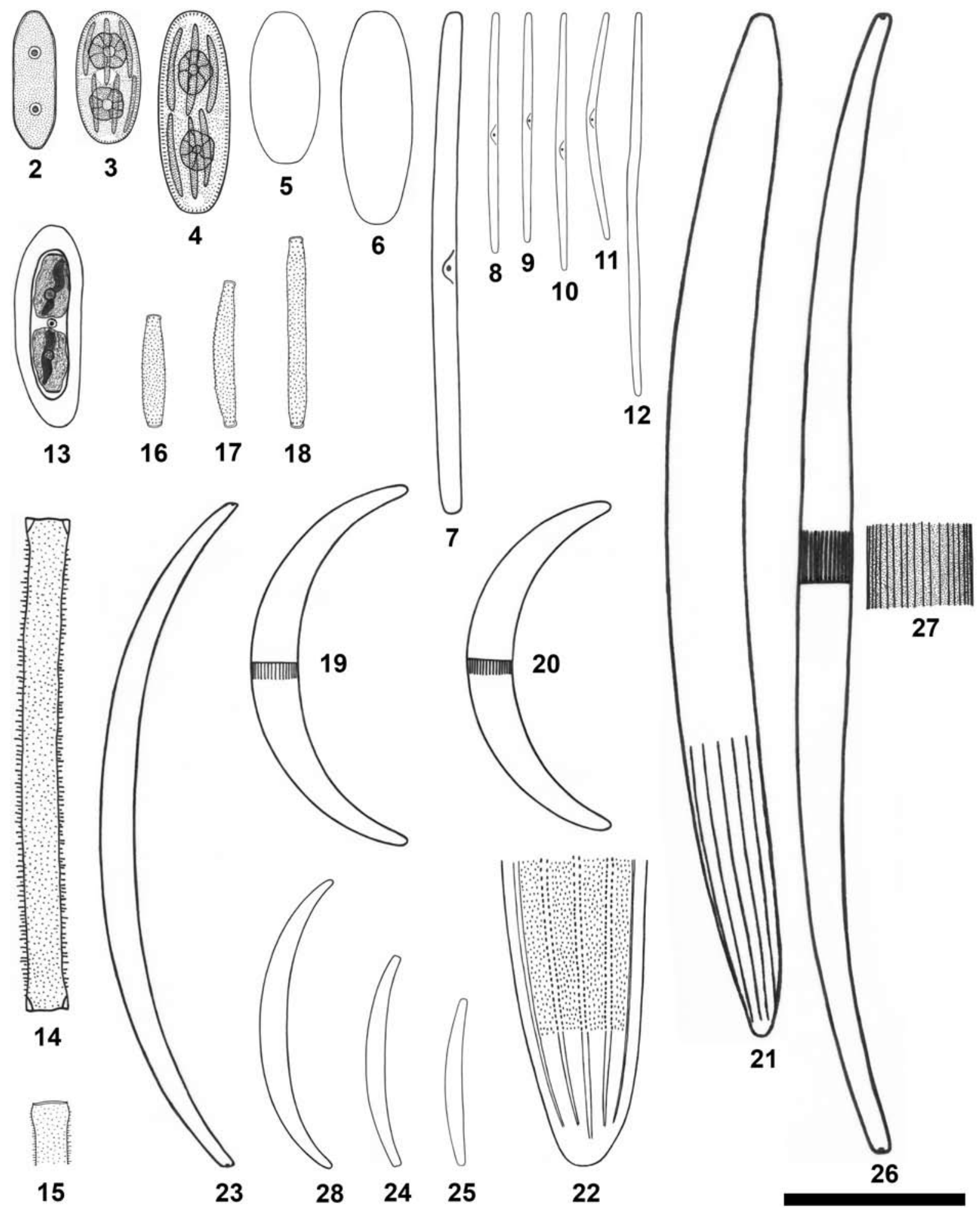

Figs 2-28. (2) Mesotaenium caldariorum; (3-6) Netrium pseudactinotaenium; (7) Roya cambrica; (8-12) R. closterioides, (12) dividing cell; (13) Tortitaenia bahusiensis; (14-15) Gonatozygon aculeatum; (16-18) G. brebissonii var. alpestre; (19-20) Closterium archerianum var. pseudocynthia; (21-22) Cl. braunii, (22) detail of cell wall sculpture; (23) Cl. calosporum var. brasiliense; (24-25) Cl. cornu var. upsaliense; (26-27) Cl. delpontei, (27) detail of cell wall sculpture; (28) Cl. exile. Scale bar $50 \mu \mathrm{m}, 100 \mu \mathrm{m}$ (for 21, 26). 

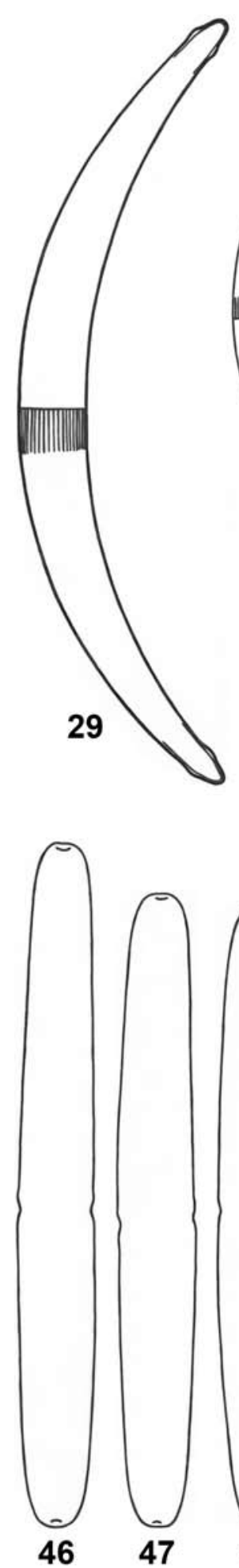

47

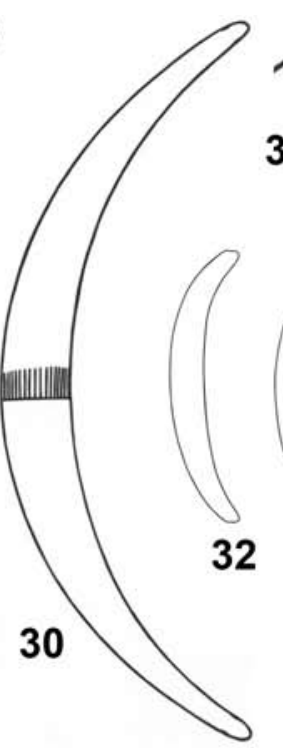

31

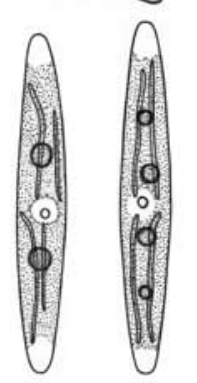

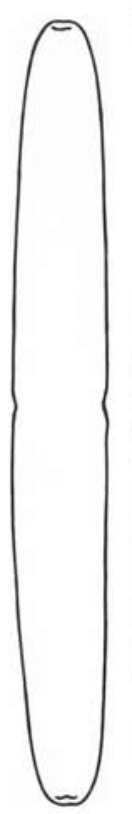

48 $\begin{array}{ll}39 & 40\end{array}$

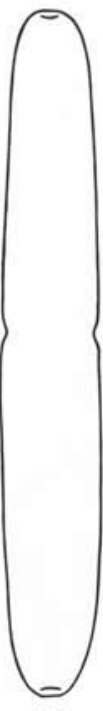

49

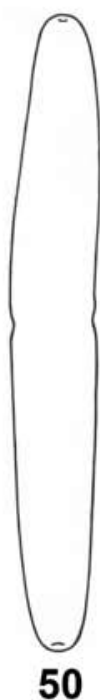

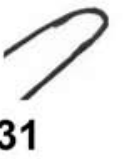
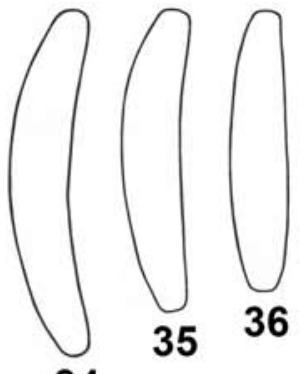

33
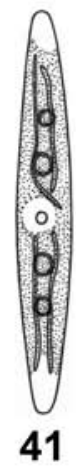

34

35
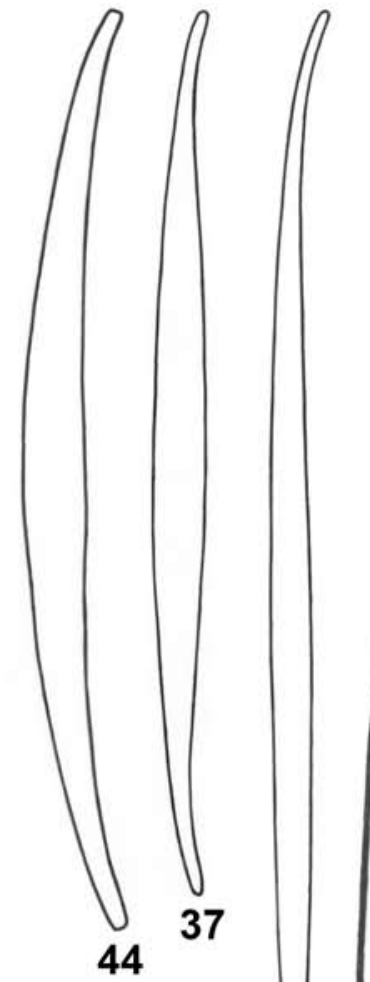

1
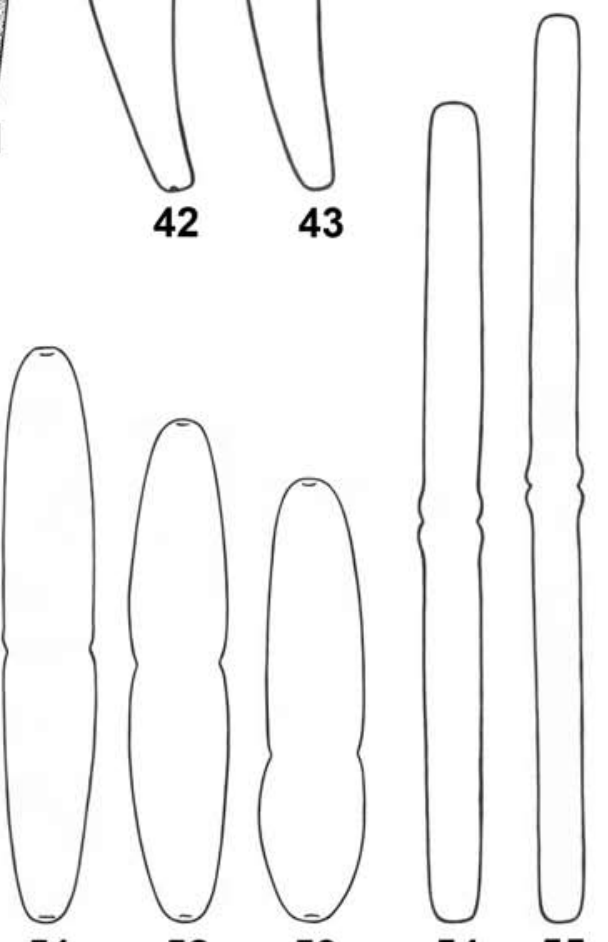

54

55

Figs 29-55. (29-31) Closterium nematodes var. proboscideum, (31) detail of the apex; (32-33) Cl. pseudopygmaeum; (34-36) Cl. pusillum; (37-38) Cl. subulatum; (39-41) Cl. tortitaenoides; (42-43) Cl. tumidum; (44) Cl. tumidum var. nylandicum; (45) Cl. turgidum var. giganteum; (46-53) Haplotaenium indentatum, morpha; (54-55) H. rectum. Scale bar $50 \mu \mathrm{m}$ (for 31-44, 46-53), $100 \mu \mathrm{m}$ (for 29, 30, 54, 55), $150 \mu \mathrm{m}$ (for 45). 


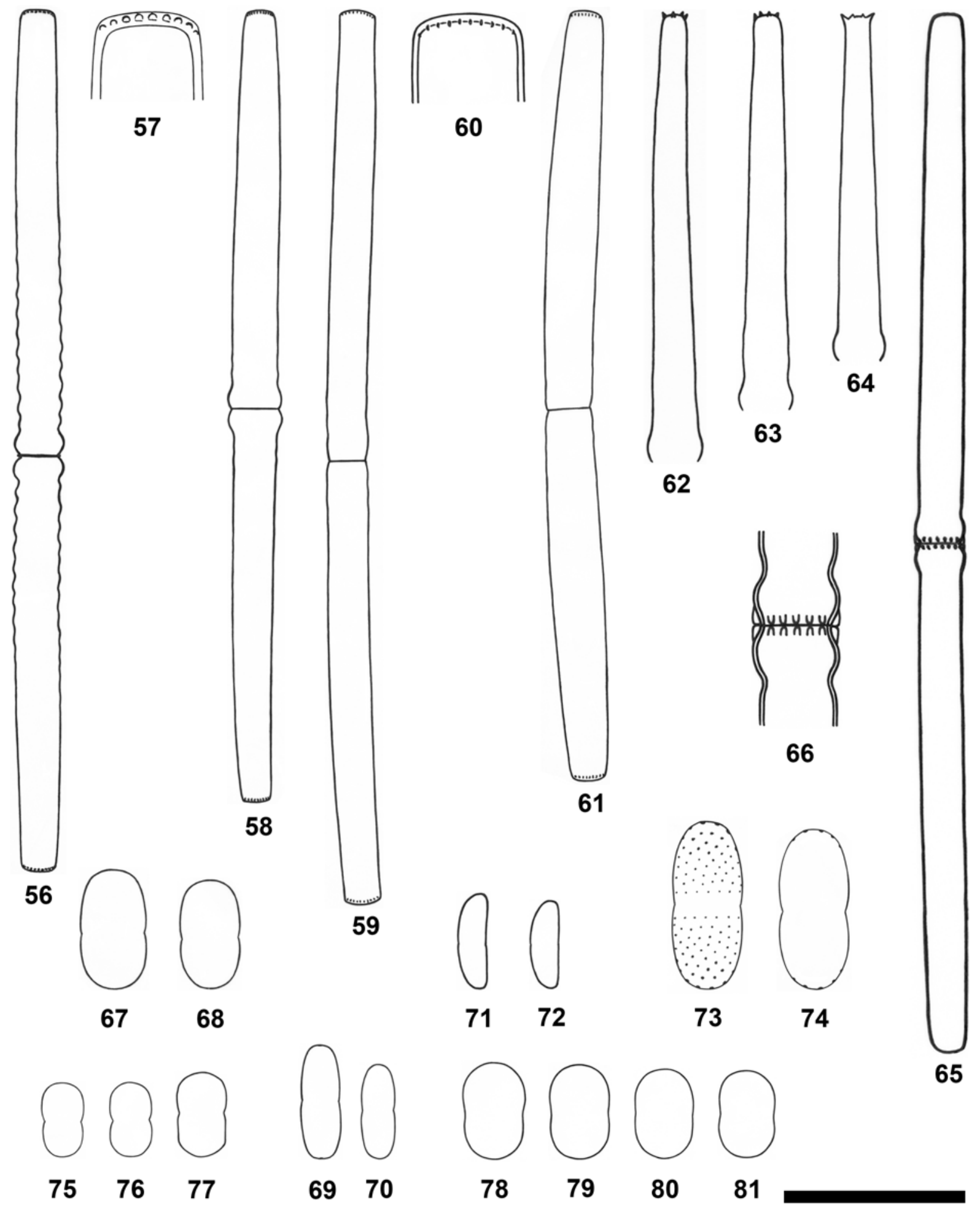

Figs 56-81. (56-58) Pleurotaenium eugeneum, (57) detail of the apex; (59-61) Pl. simplicissimum, (60) detail of the apex; (6264) Pl. tridentulum (semicells); (65-66) Docidium baculum, (66) detail of the central part of the cell; (67-68) Actinotaenium cruciferum; (69-70) A. inconspicuum; (71-72) A. inconspicuum var. curvatum; (73-74) A. kriegeri; (75-77) A. perminutum; (78-81) A. subsparsepunctatum. Scale bar $30 \mu \mathrm{m}$ (for 66-81), $50 \mu \mathrm{m}$ (for 57, 60, 62-65), $150 \mu \mathrm{m}$ (for 56, 58, 59, 61). 


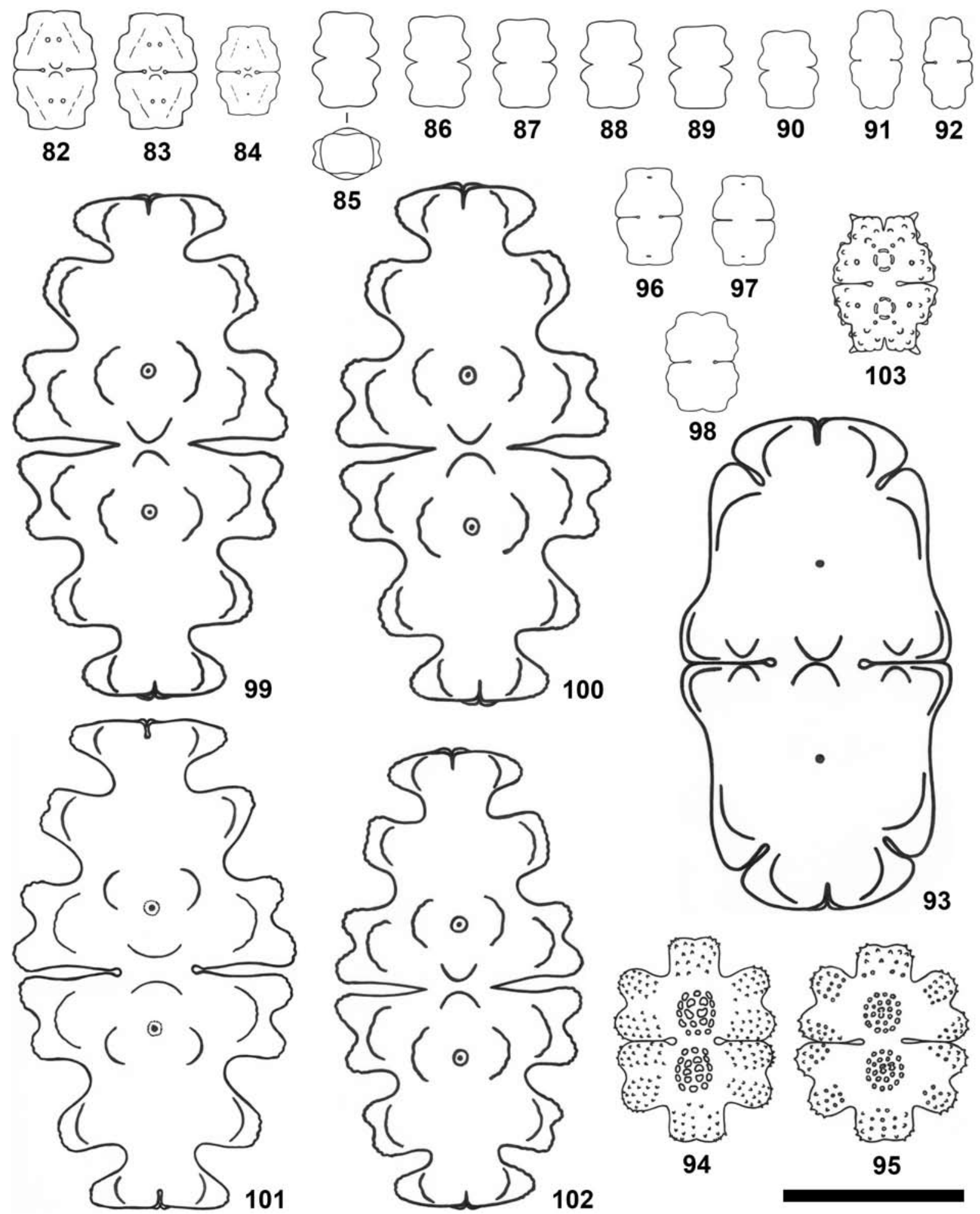

Figs 82-103. (82-84) Euastrum biscrobiculatum; (85-90) E. brevisinuosum var. dissimile; (91-92) E. crassicolle; (93) E. crassum; (94-95) E. germanicum; (96-97) E. luetkemuelleri var. carniolicum; (98) E. montanum; (99-102) E. pinnatum; (103) E. turneri. Scale bar $50 \mu \mathrm{m}$. 

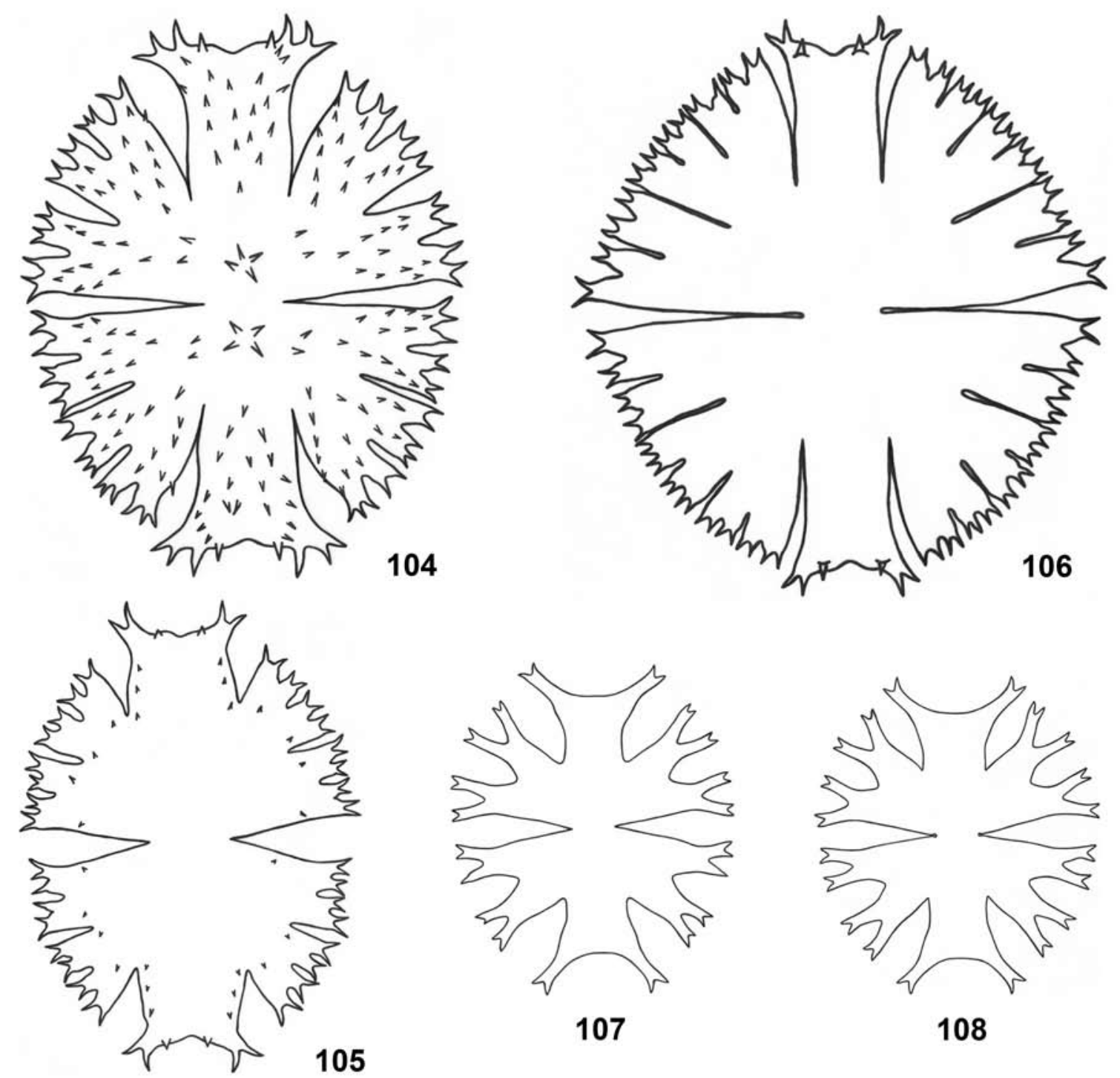

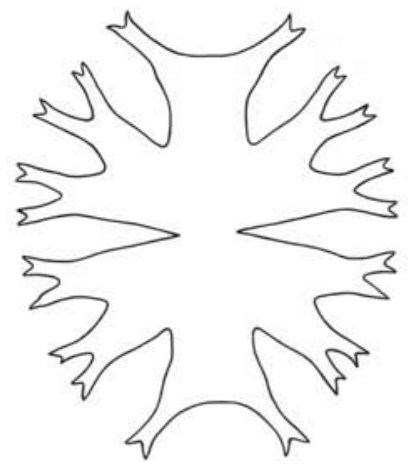

107

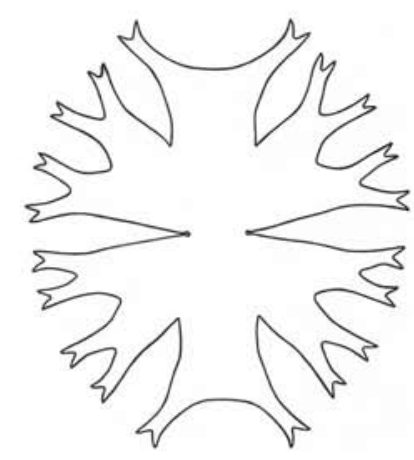

108

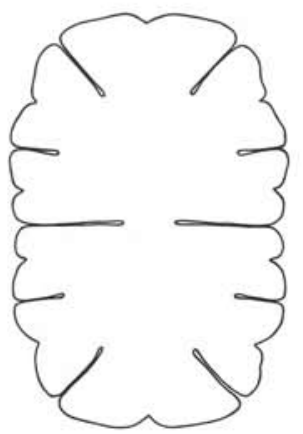

109

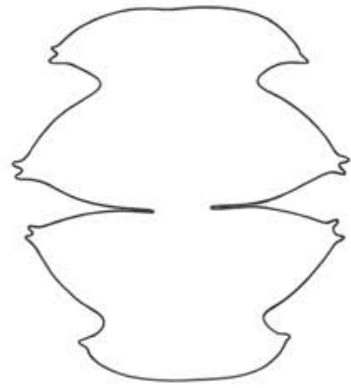

110

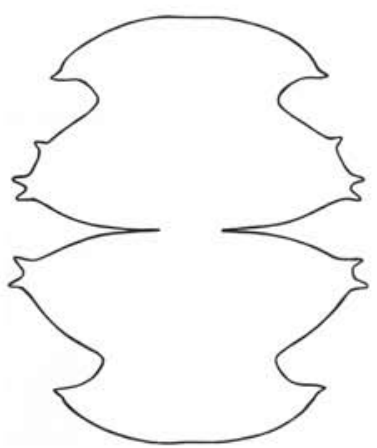

111

Figs 104-112. (104) Micrasterias apiculata; (105) M. brachyptera; (106) M. fimbriata; (107-108) M. furcata; (109) M. jenneri; (110-111) M. oscitans; (112) M. pinnatifida. Scale bar $100 \mu \mathrm{m}$. 


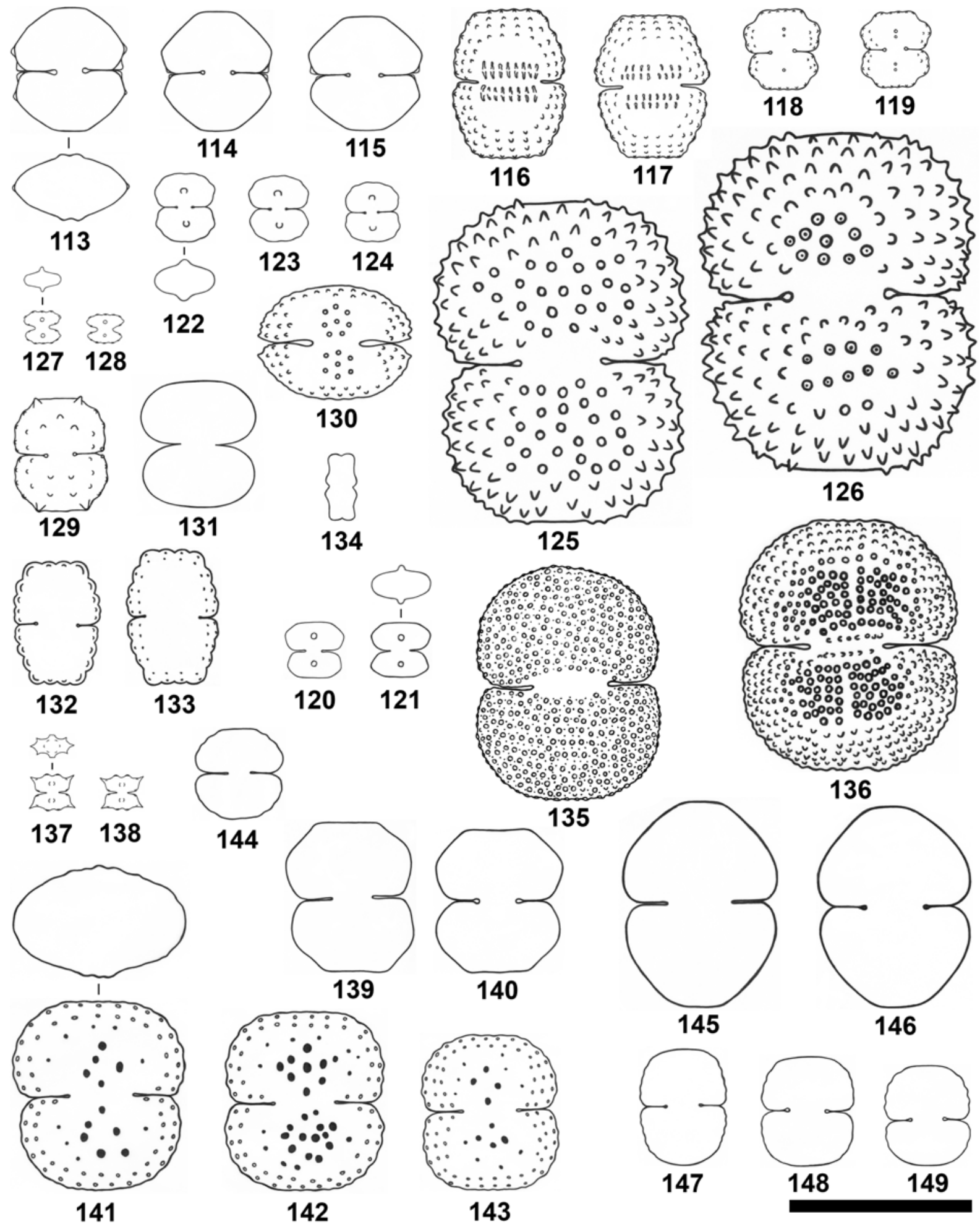

Figs 113-149. (113-115) Cosmarium angulare; (116-117) C. basiornatum; (118-119) C. berryense; (120-121) C. bireme; (122-124) C. boitierense; (125-126) C. brebissonii; (127-128) C. carinthiacum; (129) C. ceratophorum; (130) C. commisurale var. acutum; (131) C. contractum var. retusum; (132-133) C. davidsonii; (134) C. decedens var. minutum; (135) C. dentiferum var. alpinum; (136) C. didymoprotupsum; (137-138) C. dilatatum; (139-140) C. eichlerianum; (141-143) C. fastidiosum; (144) C. fontigenum; (145-146) C. galeritum; (147-149) C. garrolense. Scale bar $50 \mu \mathrm{m}$. 


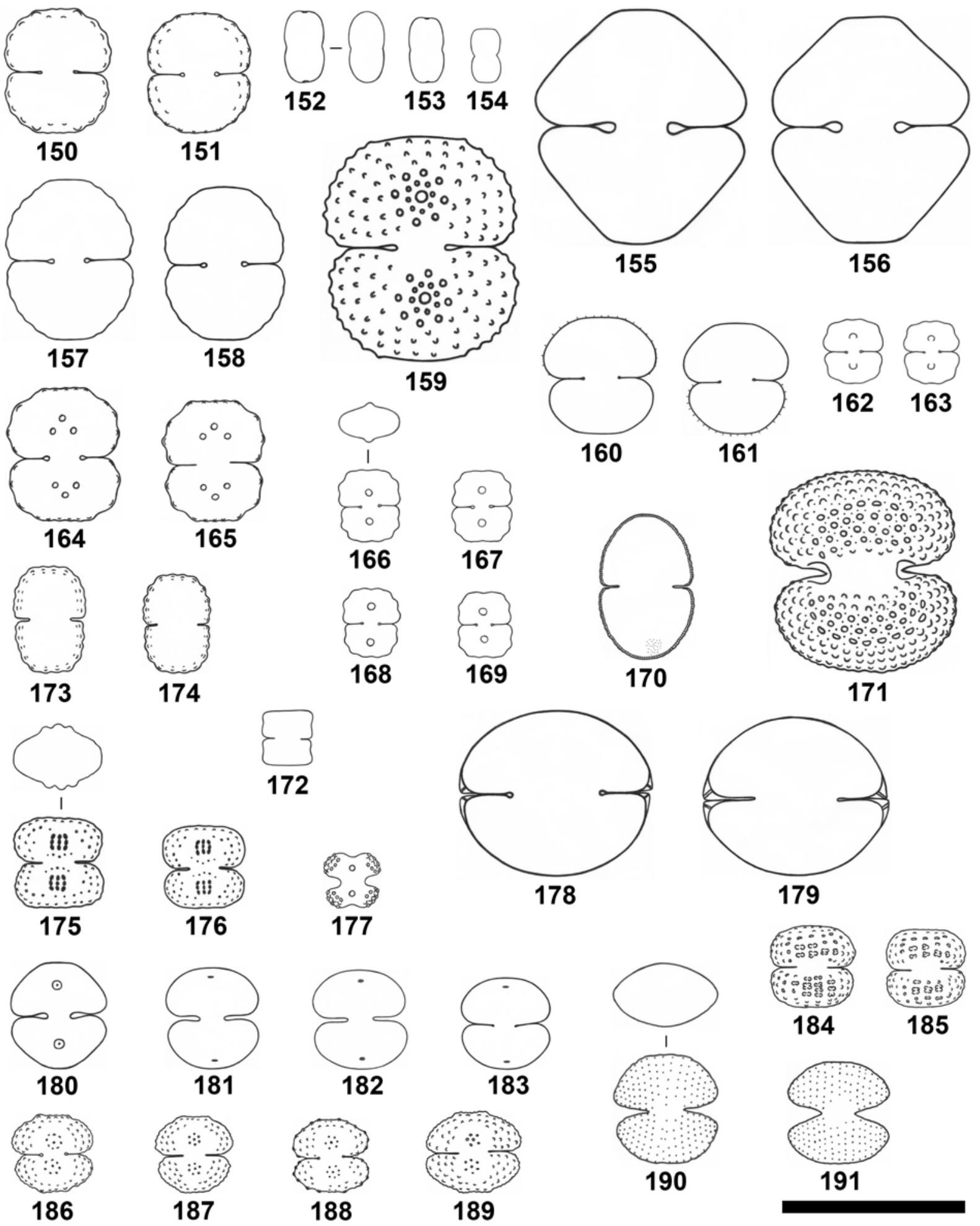

Figs 150-191. (150-151) Cosmarium gibberulum; (152-154) C. goniodes var. subturgidum; (155-156) C. homalodermum; (157-158) C. jaoi; (159) C. kirchneri; (160-161) C. klebsii; (162-163) C. lagerheimii; (164-165) C. limnophilum; (166-169) C. medioretusum; (170) C. microsphinctum var. crispulum; (171) C. netzerianum; (172) C. norimbergense var. depressum; (173-174) C. notabile; (175-176) C. notatum; (177) C. novae-semliae var. granulatum; (178-179) C. obsoletum; (180) C. ocellatum; (181-183) C. ocellatum var. notatum. (184-185) C. ordinatum; (186-188) C. ornatulum; (189) C. ornatulum var. depressum; (190-191) C. orthopunctulatum. Scale bar $50 \mu \mathrm{m}$. 


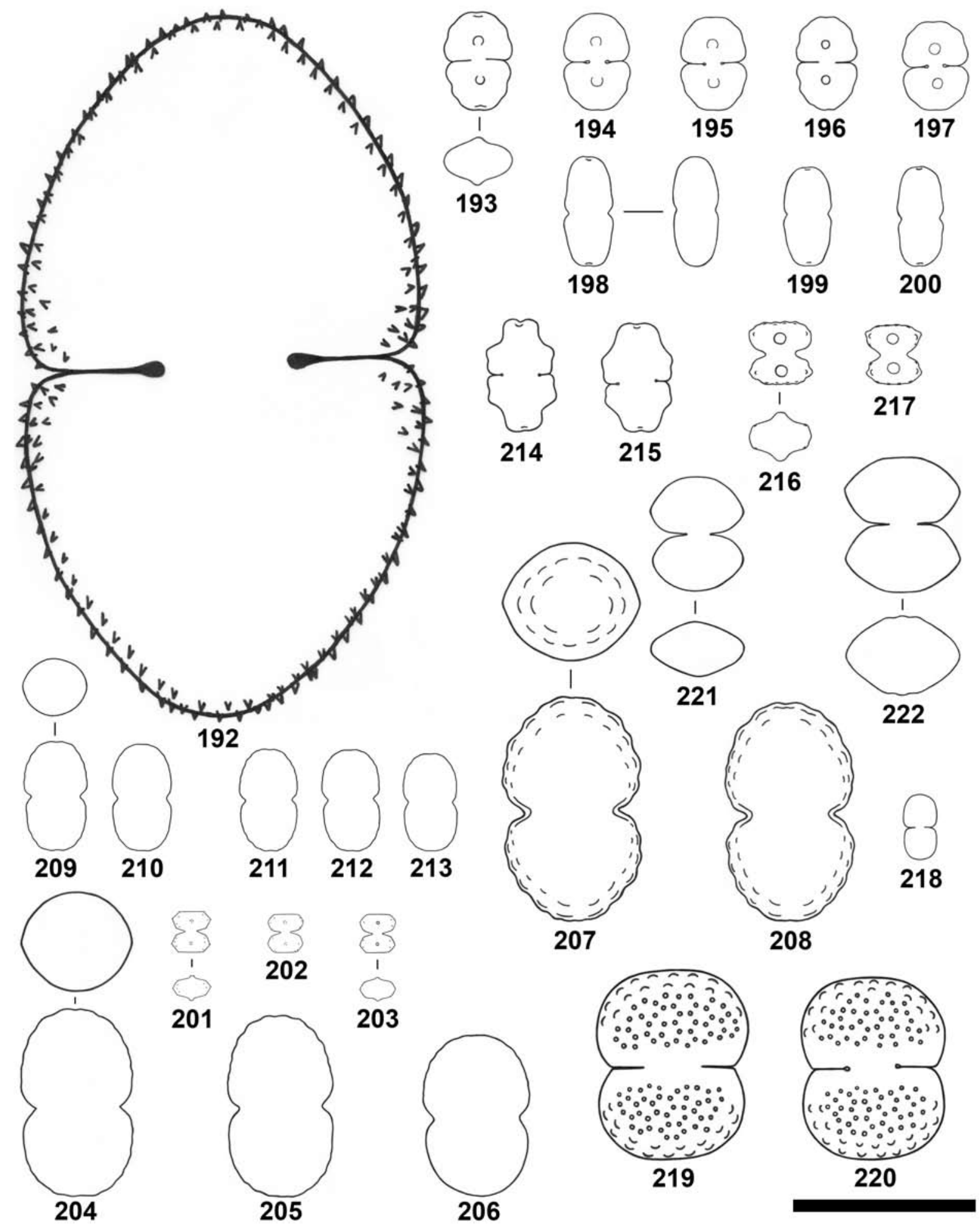

Figs 192-222. (192) Cosmarium ovale; (193-197) C. paragranatoides; (198-200) C. parvulum var. undulatum; (201-203) C. paucigranulatum; (204-206) C. pericymatium; (207-208) C. pericymatium var. corrugatum; (209-213) C. pericymatium var. notabiliforme; (214-215) C. pokornyanum; (216-217) C. prominulum var. subundulatum; (218) C. pseudoexiguum; (219-220) C. pseudoinsigne; (221) C. pseudoprotuberans; (222) C. pseudoprotuberans var. sulcatum. Scale bar $50 \mu \mathrm{m}$. 


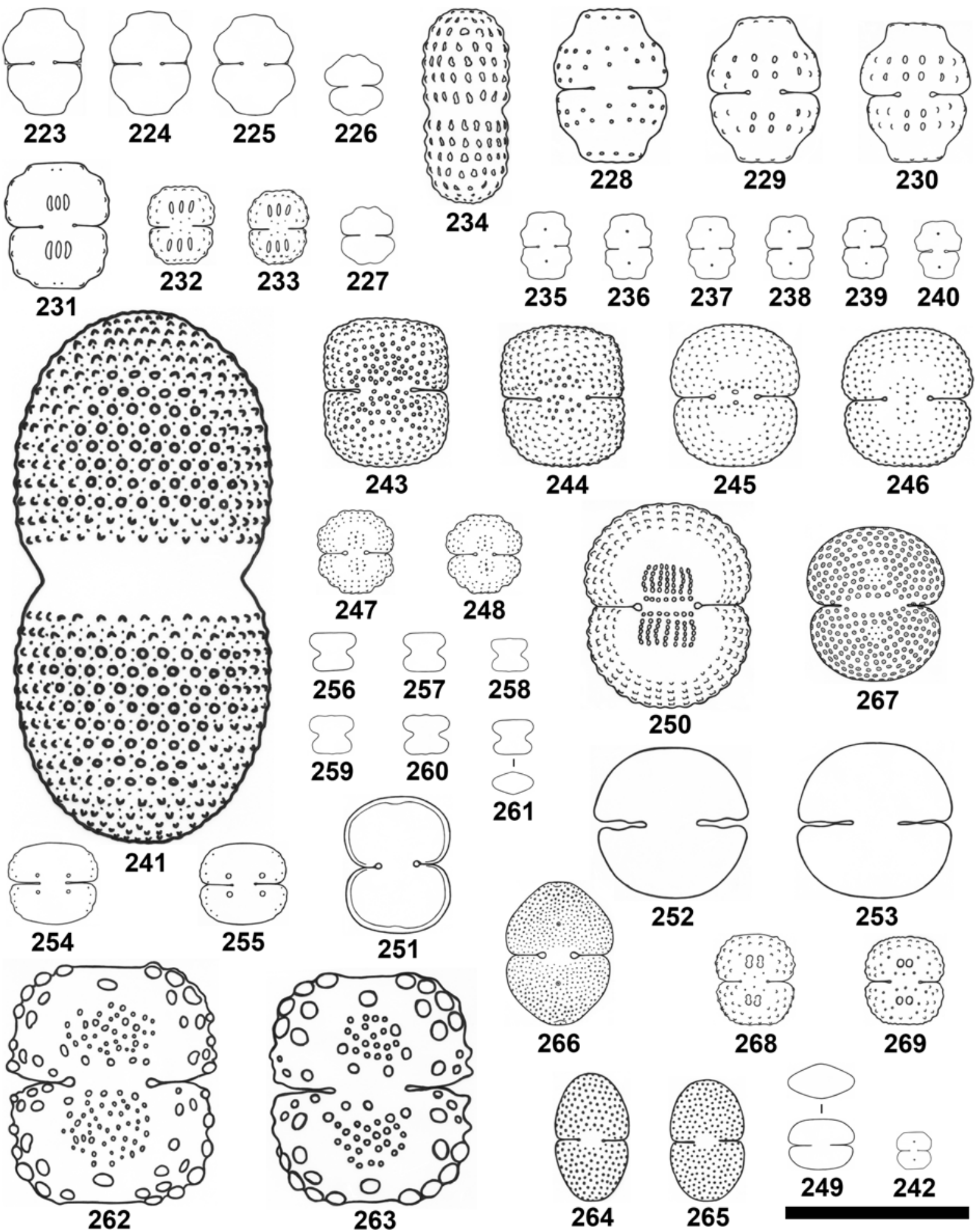

Figs 223-269. (223-225) Cosmarium pseudoretusum; (226-227) C. pseudowembaerense; (228-230) C. retusum; (231) C. sexnotatum var. bipunctatum; (232-233) C. sexnotatum var. tristriatum; (234) C. simplicius; (235-240) C. sphyrelatum; (241) C. striolatum; (242) C. subadoxum; (243-244) C. subbroomei; (245-246) C. subbroomei f. isthmochondrum; (247248) C. subprotumidum var. pyramidale; (249) C. subquadrans var. minor; (250) C. subspeciosum; (251) C. subtumidum var. groenbladii; (252-253) C. taxichondriforme; (254-255) C. tetrachondrum, forma. (256-261) C. truncatellum; (262-263) C. ungerianum var. subtriplicatum; (264-265) C. variolatum; (266) C. variolatum var. cataractarum; (267) C. varsoviense; (268-269) C. vogesiacum. Scale bar $50 \mu \mathrm{m}$. 

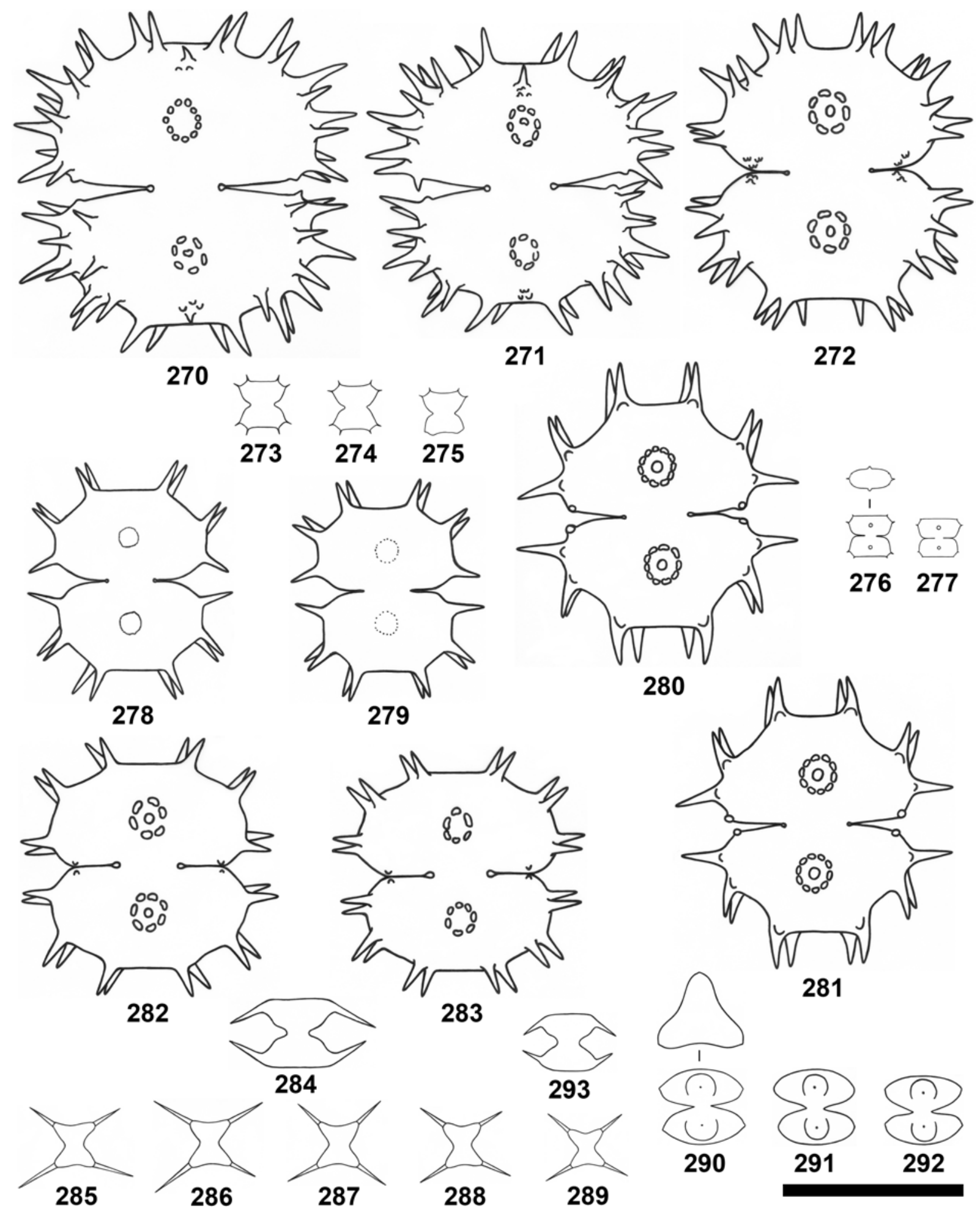

Figs 270-293. (270-271) Xanthidium aculeatum; (272) X. basidentatum; (273-275) X. bifidum. (276-277) X. concinnum; (278-279) X. cristatum; (280-281) X. cristatum var. uncinatum f. polonicum; (282-283) X. fasciculatum var. oronense; (284) Staurodesmus extensus var. joshuae; (285-289) Std. extensus var. malaccensis; (290-292) Std. lanceolatus var. compressus; (293) Std. subhexagonus. Scale bar $50 \mu \mathrm{m}$. 


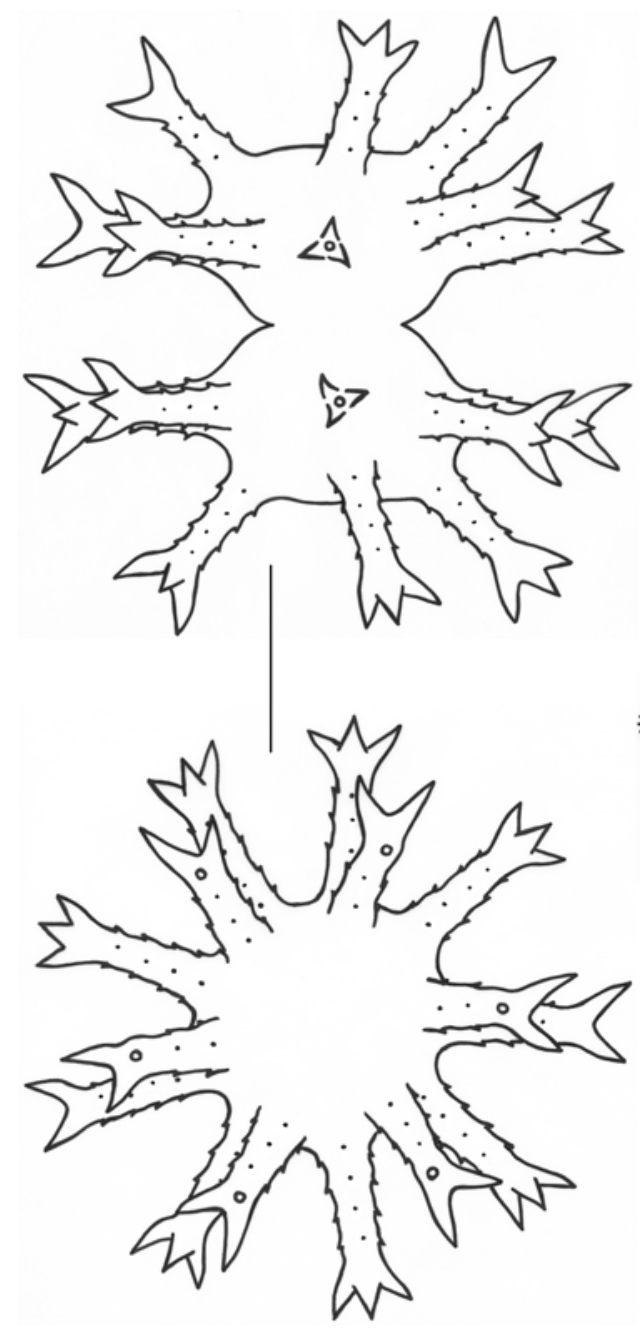

294

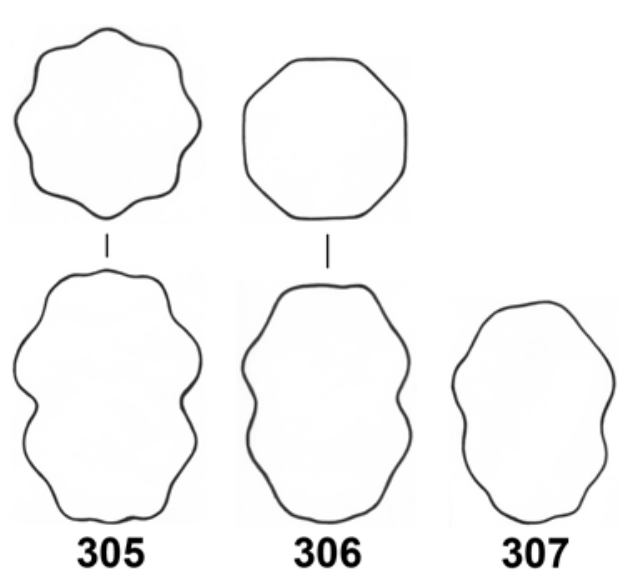

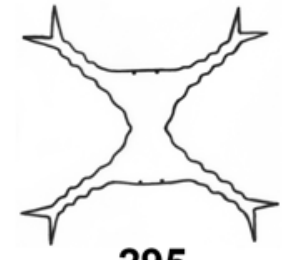

295
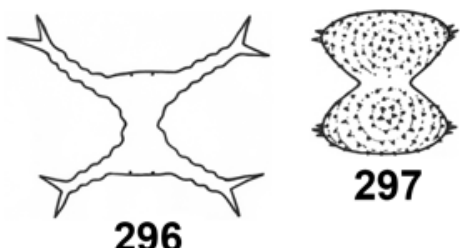

297
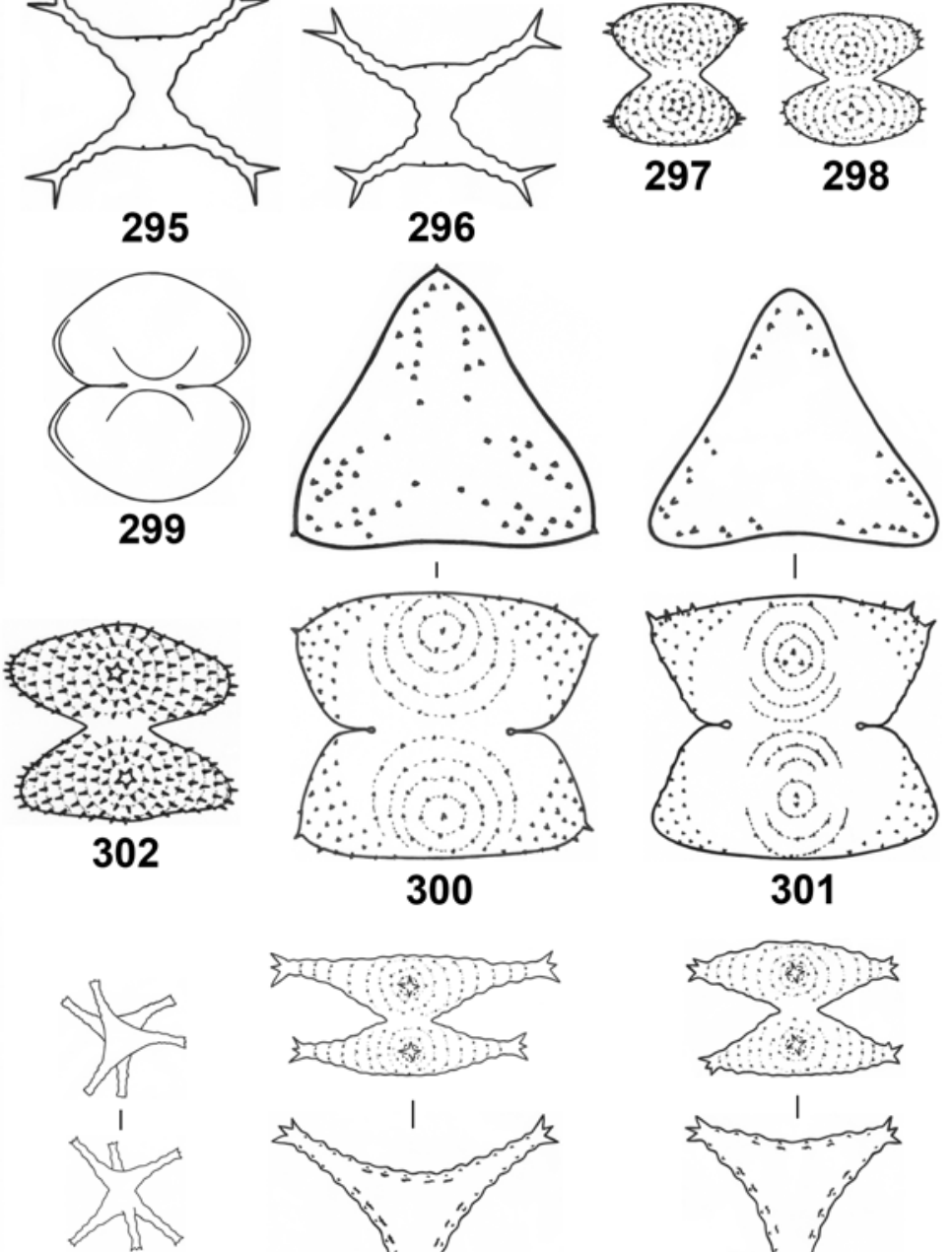

313
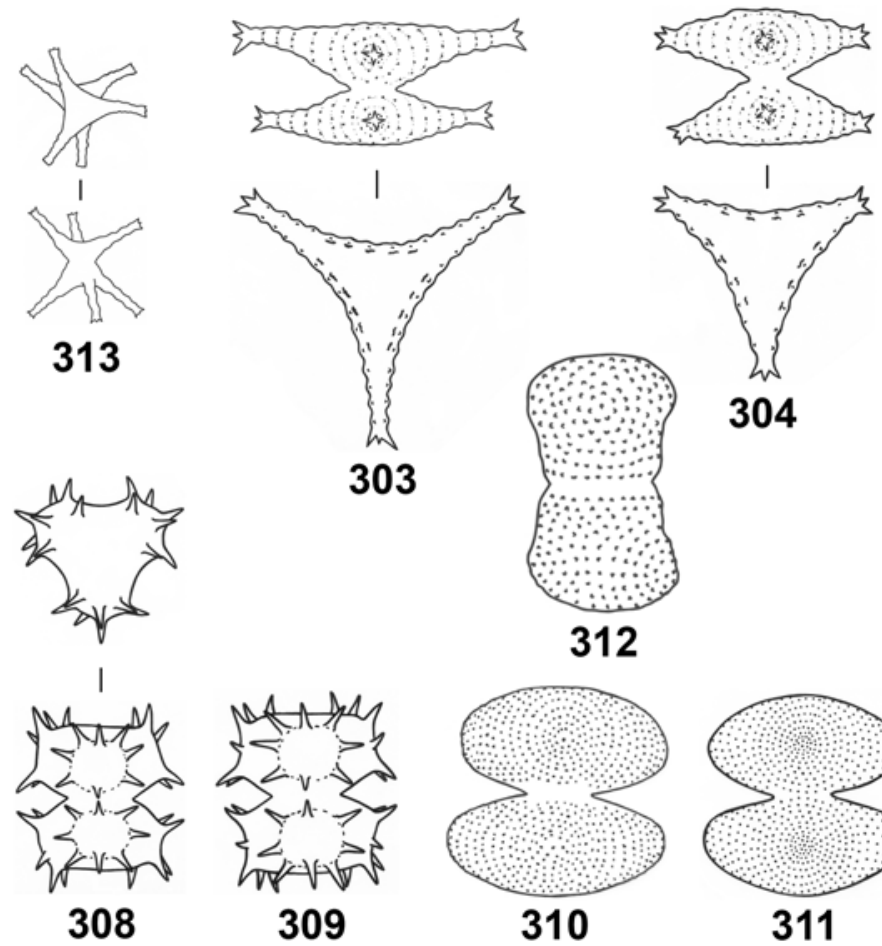

303
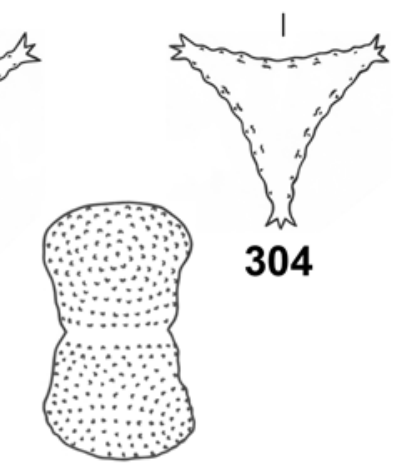

304

Figs 294-313. (294) Staurastrum arctiscon; (295-296) St. bloklandiae; (297-298) St. bohlinianum; (299) St. crassangulatum; (300-301) St. cristatum var. navigiolum; (302) St. erasum; (303-304) St. eurycerum; (305-307) St. habeebense; (308-309) St. hystrix; (310-311) St. lapponicum; (312) St. meriani; (313) St. minimum. Scale bar $50 \mu \mathrm{m}$. 

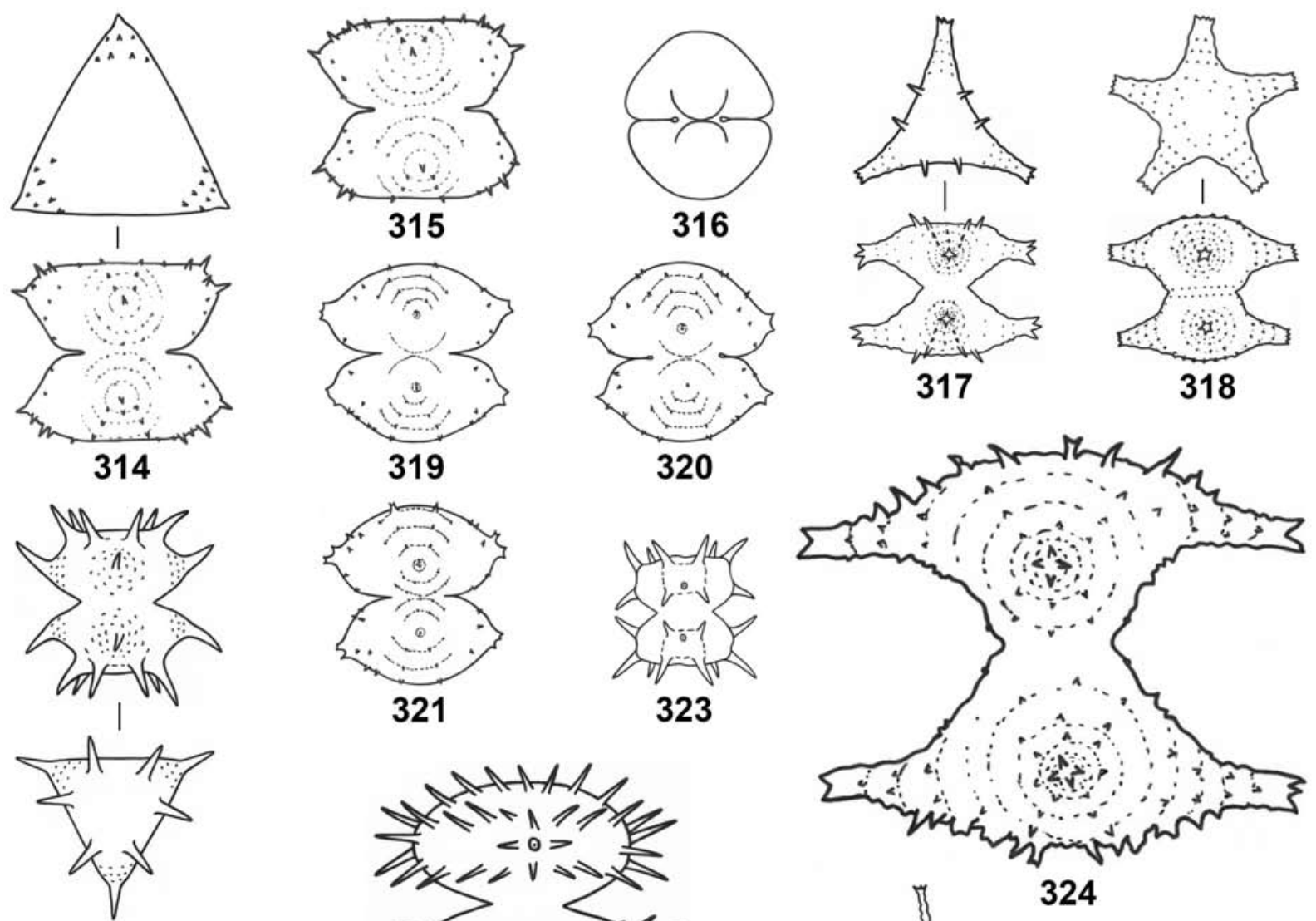

323
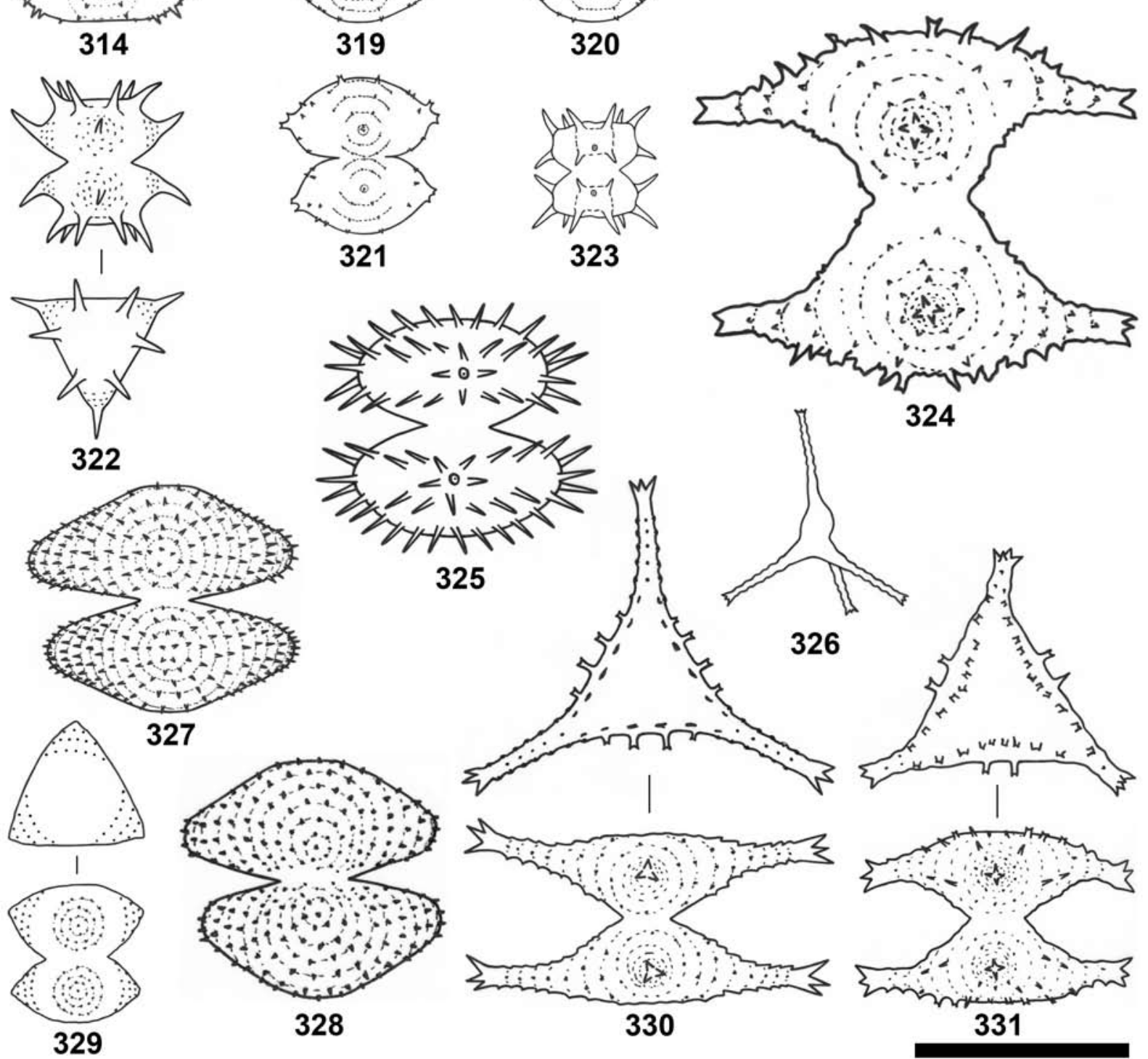

Figs 314-331. (314-315) Staurastrum oligacanthum; (316) St. orbiculare var. ralfsii; (317) St. oxyacanthum; (318) St. pentasterias; (319-321) St. podlachicum; (322) St. pungens; (323) St. quadrispinatum; (324) St. sebaldi; (325) St. setigerum; (326) St. smithii; (327-328) St. trapezicum; (329) St. varians; (330-331) St. vestitum. Scale bar $50 \mu \mathrm{m}$. 

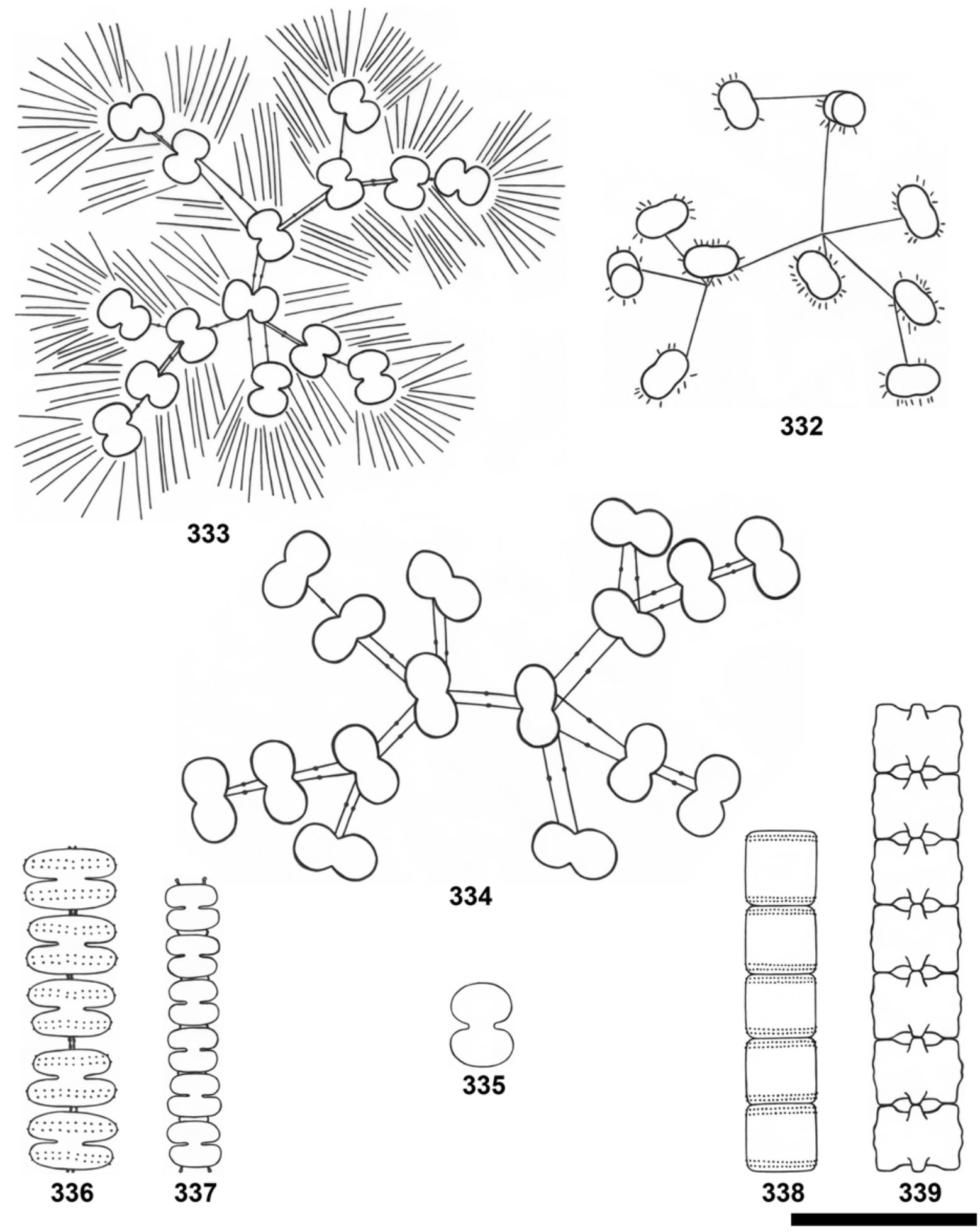

Figs 332-339. (332) Cosmocladium constrictum, part of a cell colony; (333-335) C. saxonicum; (336) Sphaerozosma aubertianum; (337) Sph. filiforme; (338) Hyalotheca mucosa; (339) Desmidium baileyi var. caelatum. Scale bar $50 \mu \mathrm{m}, \quad 80$ $\mu \mathrm{m}$ (for Fig. 333). 


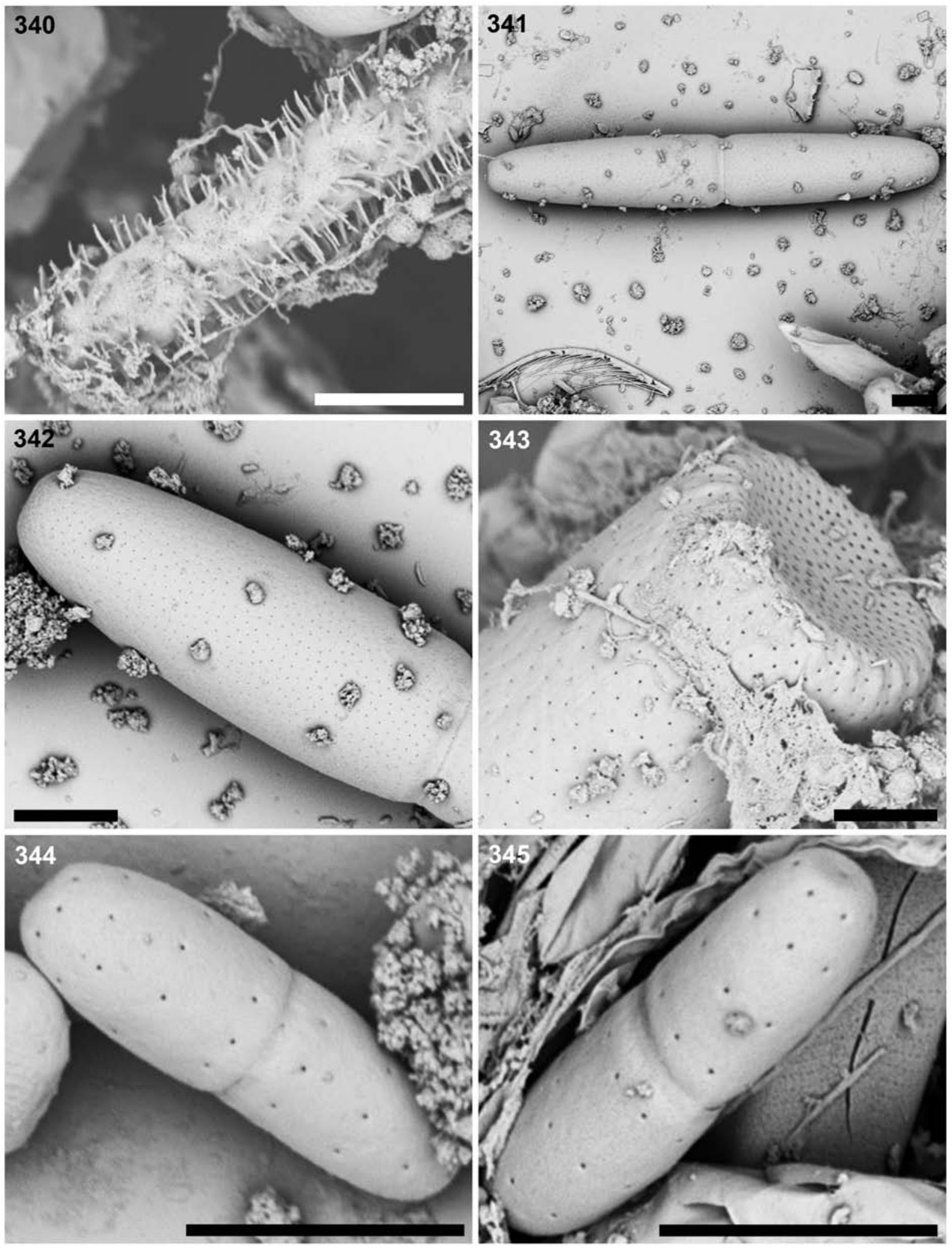

Figs 340-345. (340) Gonatozygon aculeatum; (341-342) Haplotaenium indentatum var. latius, morpha; (343) Pleurotaenium simplicissimum, apex; (344-345) Actinotaenium inconspicuum. Scale bar $10 \mu \mathrm{m}$. 

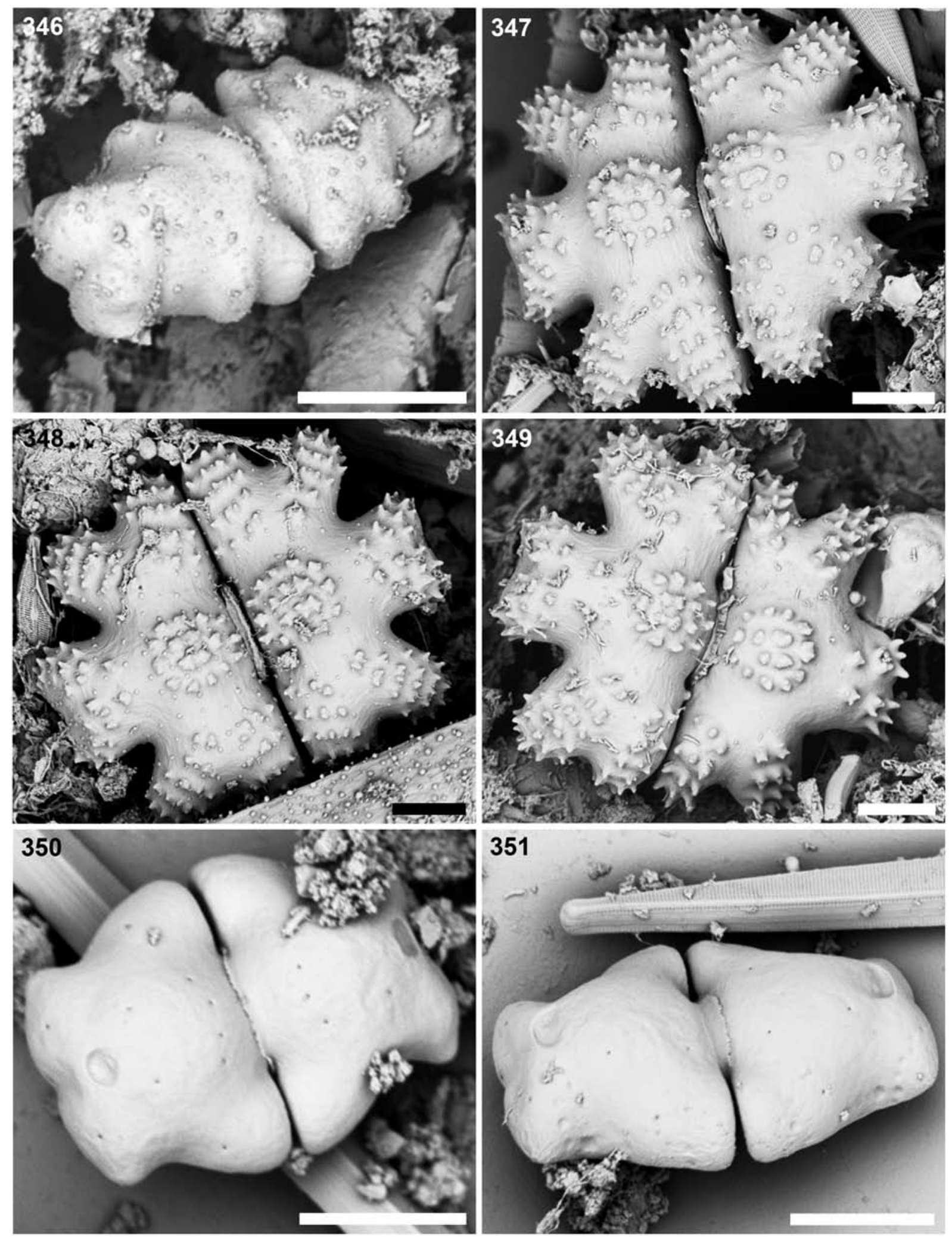

Figs 346-351. (346) Euastrum crassicolle; (347-349) E. germanicum; (350-351) E. luetkemuelleri var. carniolicum. Scale bar $10 \mu \mathrm{m}$. 

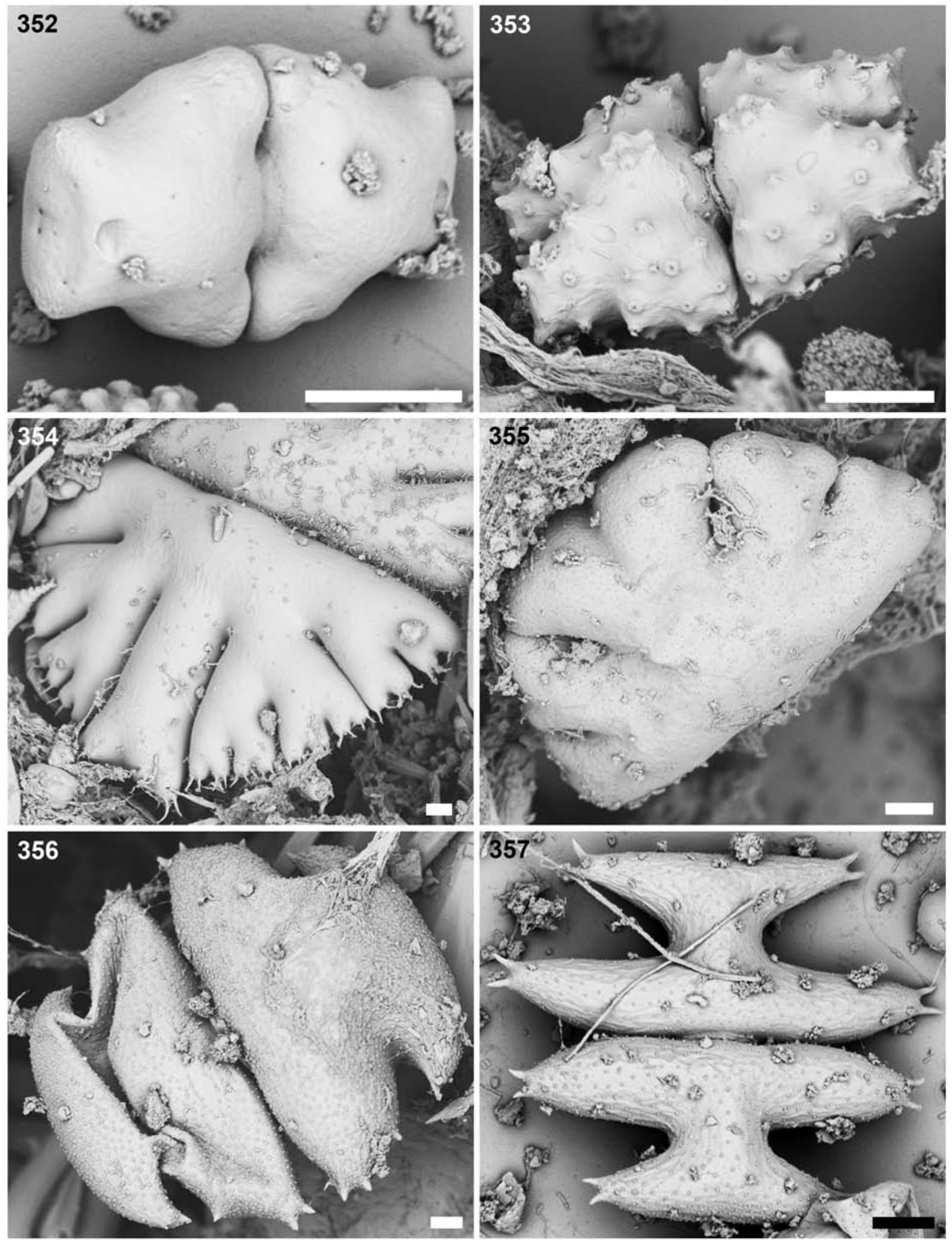

Figs (352-357). (352) Euastrum luetkemuelleri var. carniolicum; (353) E. turneri; (354) Micrasterias fimbriata; (355) M. jenneri; (356) M. oscitans; (357) M. pinnatifida. Scale bar $10 \mu \mathrm{m}$. 

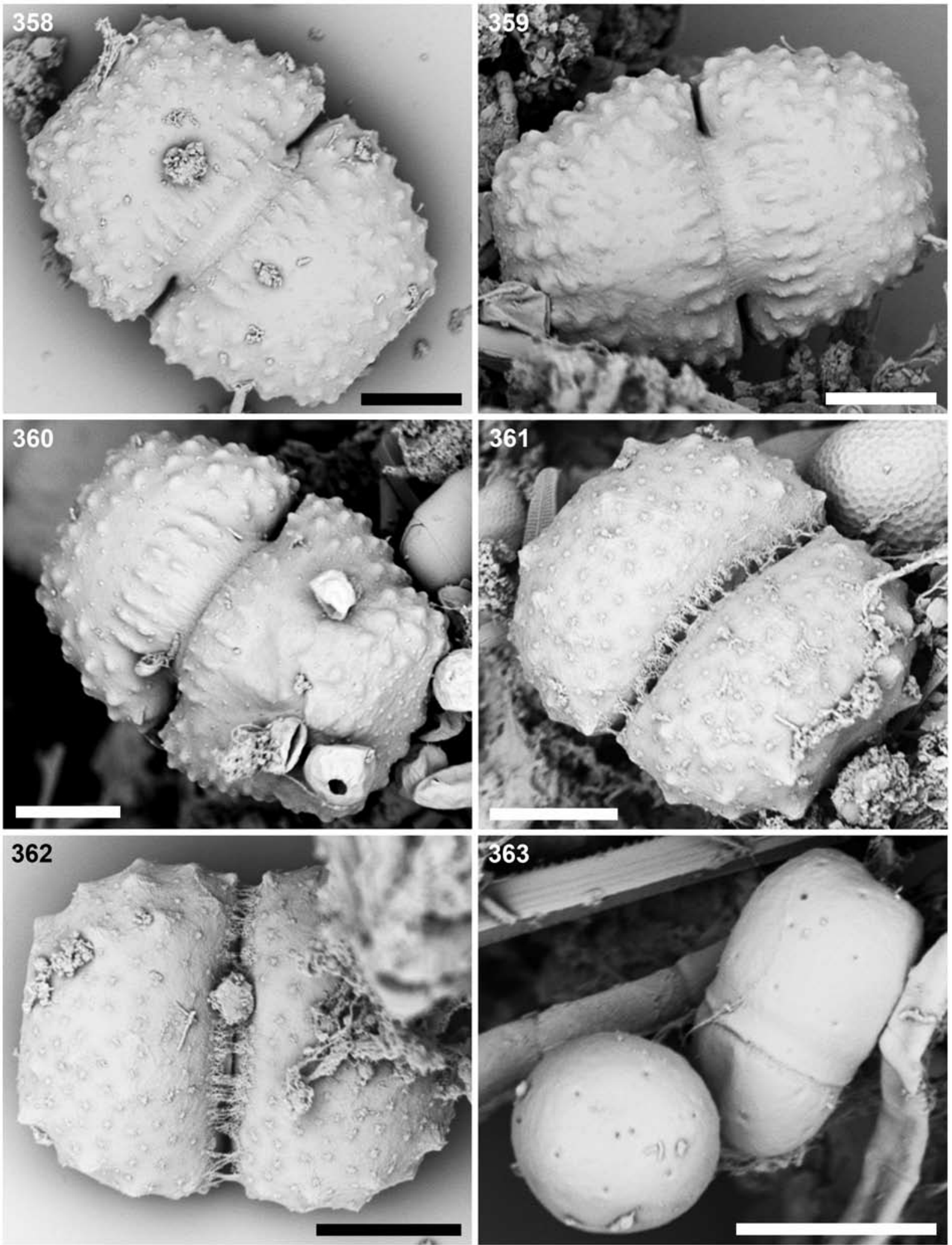

Figs 358-363. (358-360) Cosmarium basiornatum; (361-362) C. ceratophorum; (363) C. goniodes var. subturgidum. Scale bar $10 \mu \mathrm{m}$. 

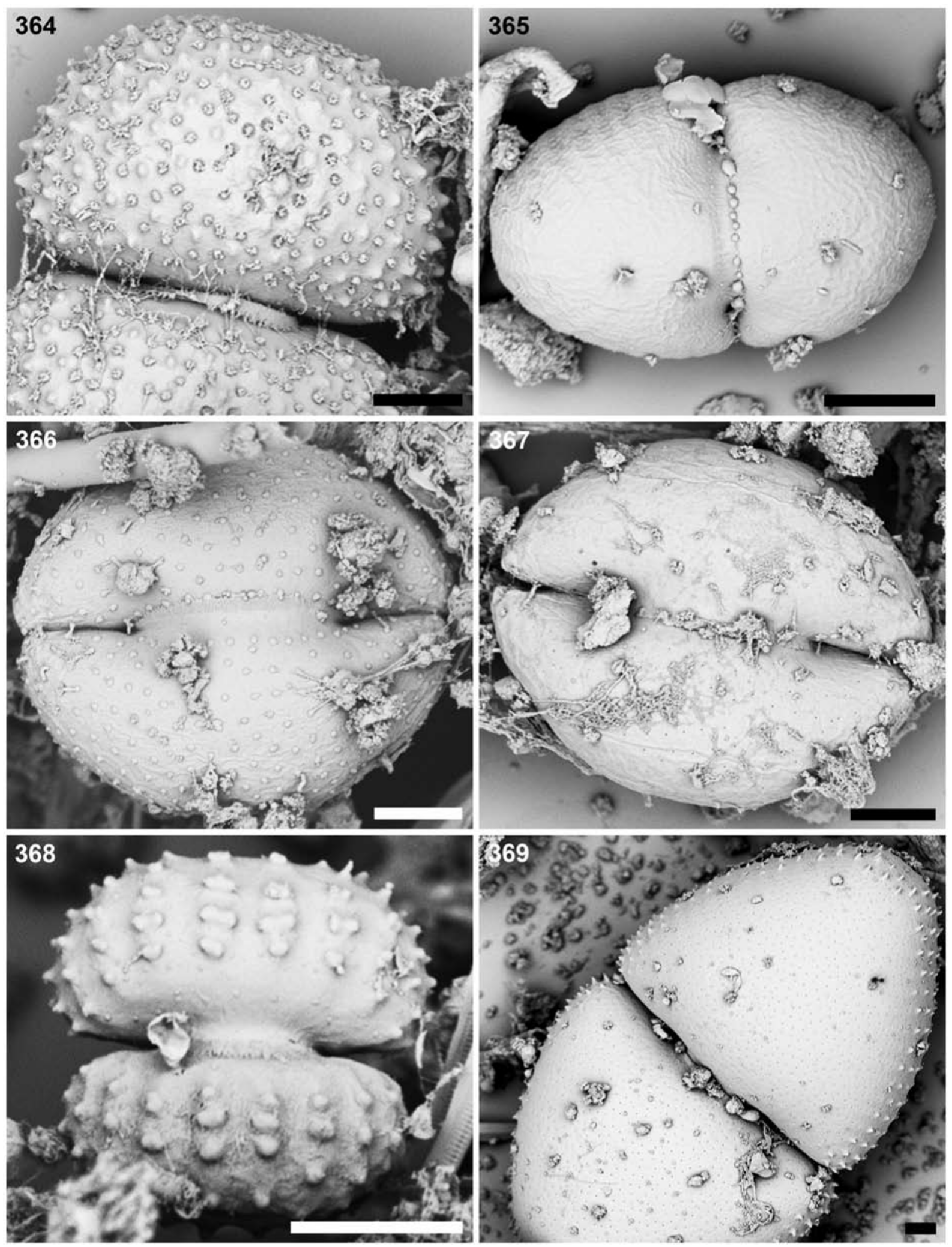

Figs 364-369. (364) Cosmarium kirchneri; (365) C. microsphinctum var. crispulum; (366-367) C. obsoletum; (368) C. ordinatum; (369) C. ovale. Scale bar $10 \mu \mathrm{m}$. 

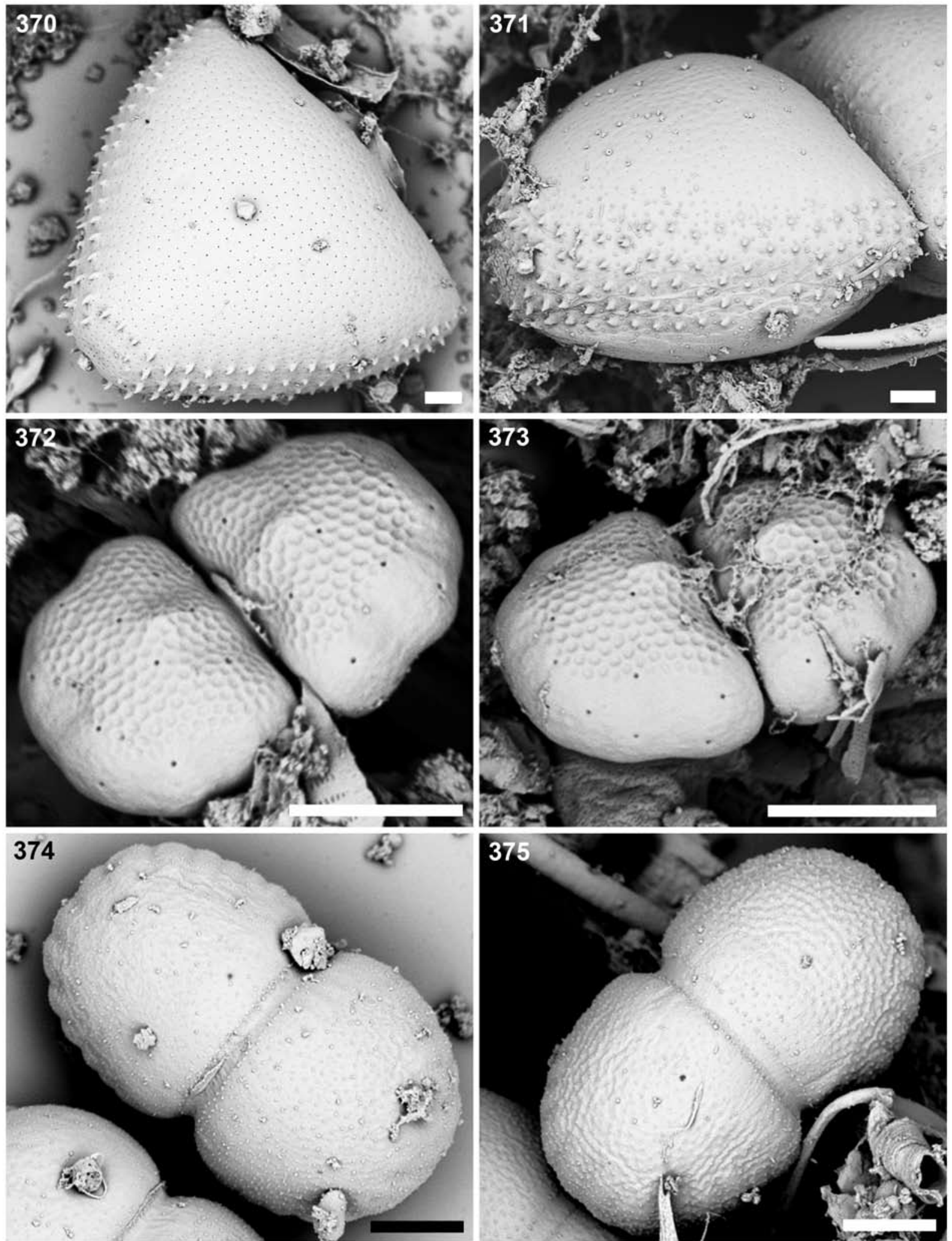

Figs 370-375. (370-371) Cosmarium ovale; (372-373) C. paragranatoides; (374-375) C. pericymatium. Scale bar $10 \mu \mathrm{m}$. 

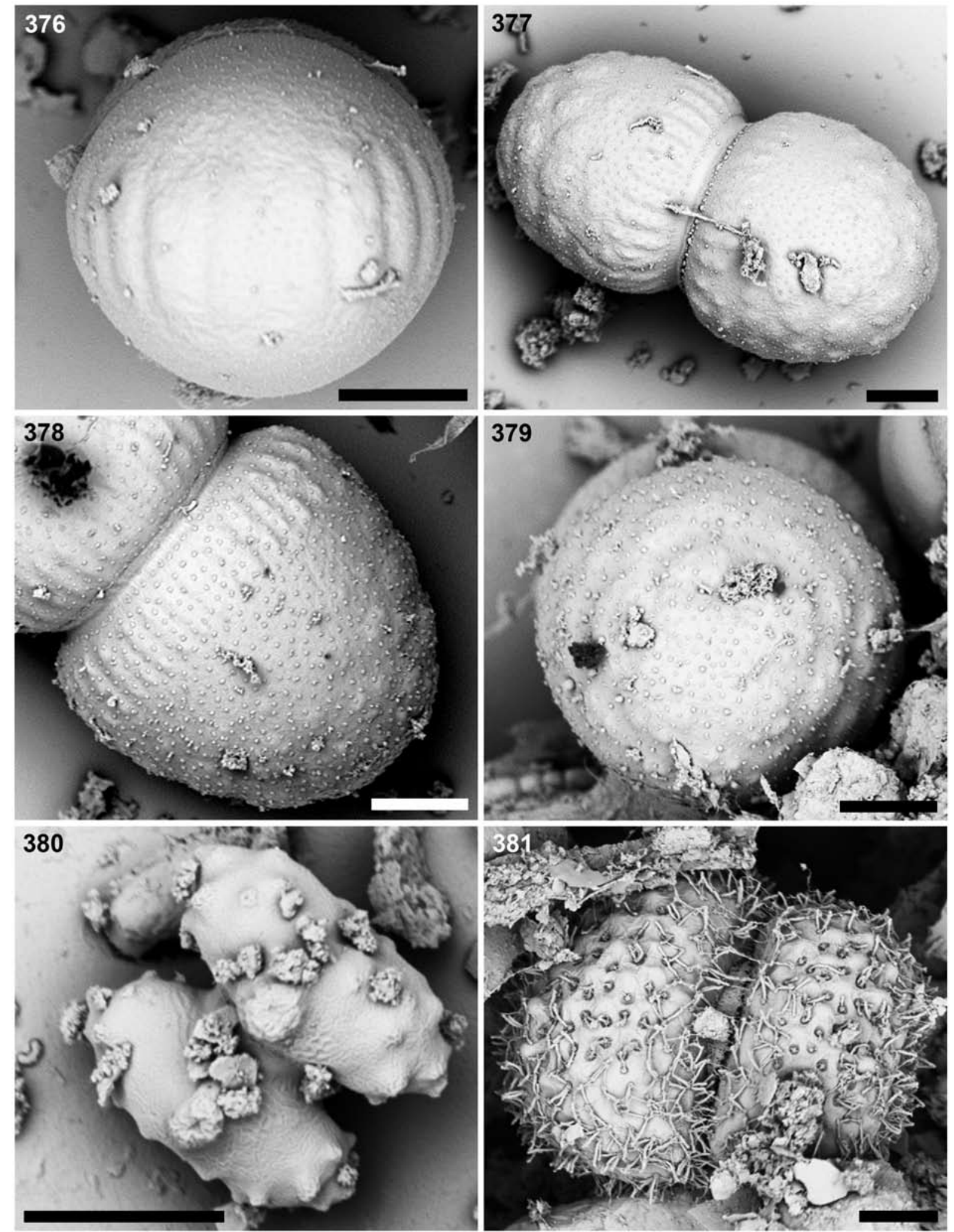

Figs 376-381. (376) Cosmarium pericymatium, apical view; (377-379) C. pericymatium var. corrugatum, (379) apical view; (380) C. prominulum var. subundulatum; (381) C. pseudoinsigne. Scale bar $10 \mu \mathrm{m}$. 

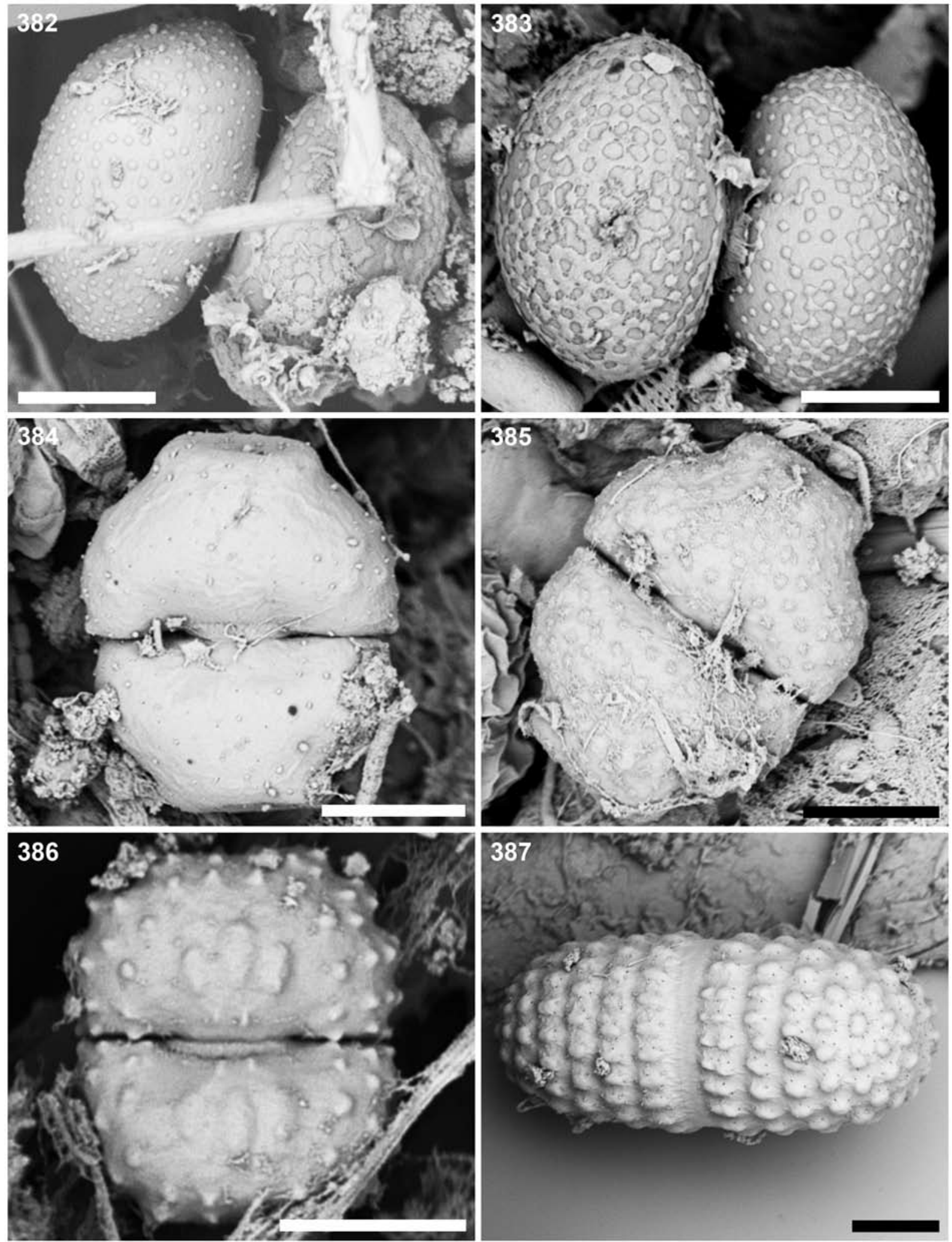

Figs 382-387. (382-383) Cosmarium pseudoprotuberans; (384-385) C. pseudoretusum; (386) C. sexnotatum var. tristriatum; (387) C. simplicius. Scale bar $10 \mu \mathrm{m}$. 

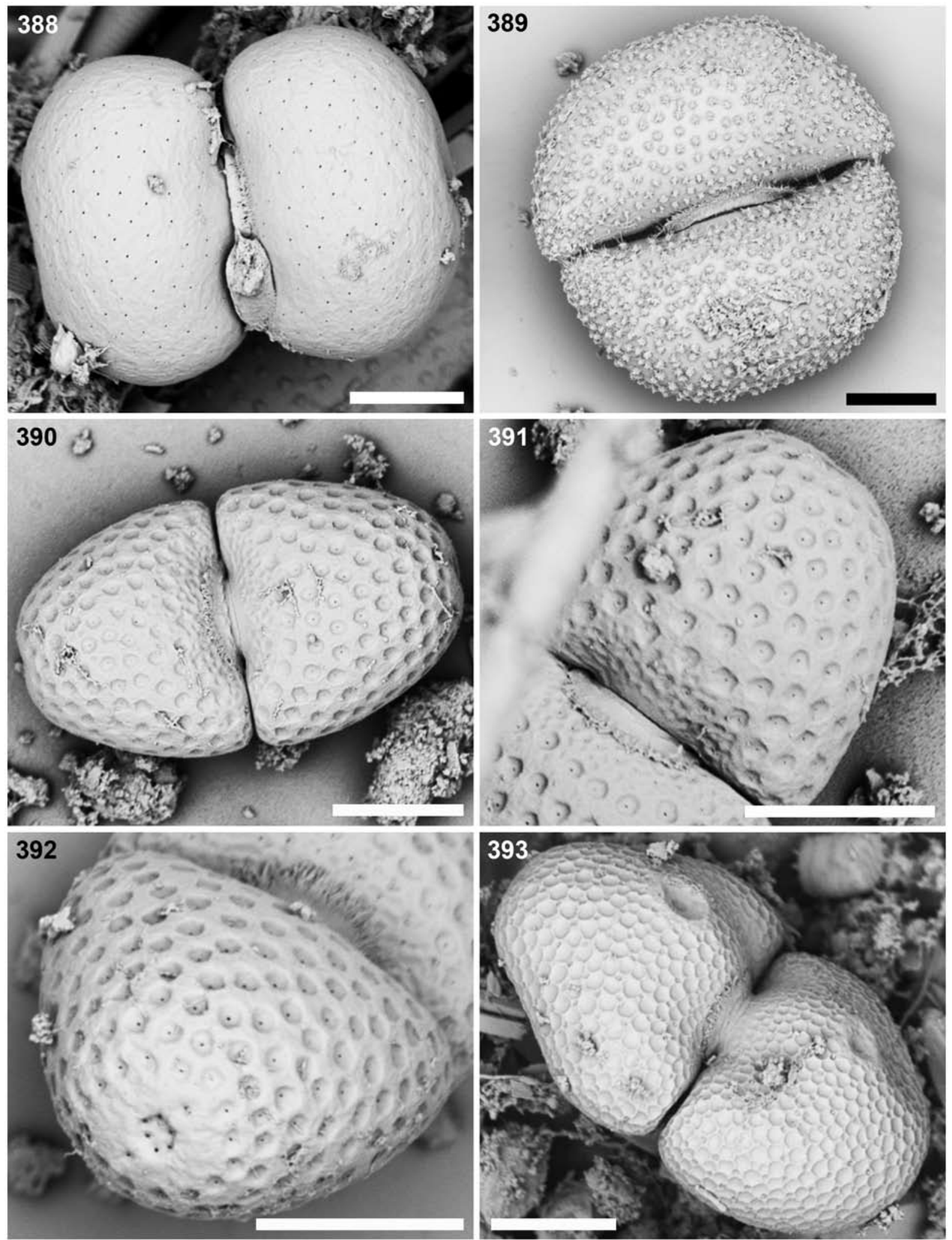

Figs 388-393. (388) Cosmarium subtumidum var. groenbladii; (389) C. taxichondriforme; (390-392) C. variolatum; (393) C. variolatum var. cataractarum. Scale bar $10 \mu \mathrm{m}$. 

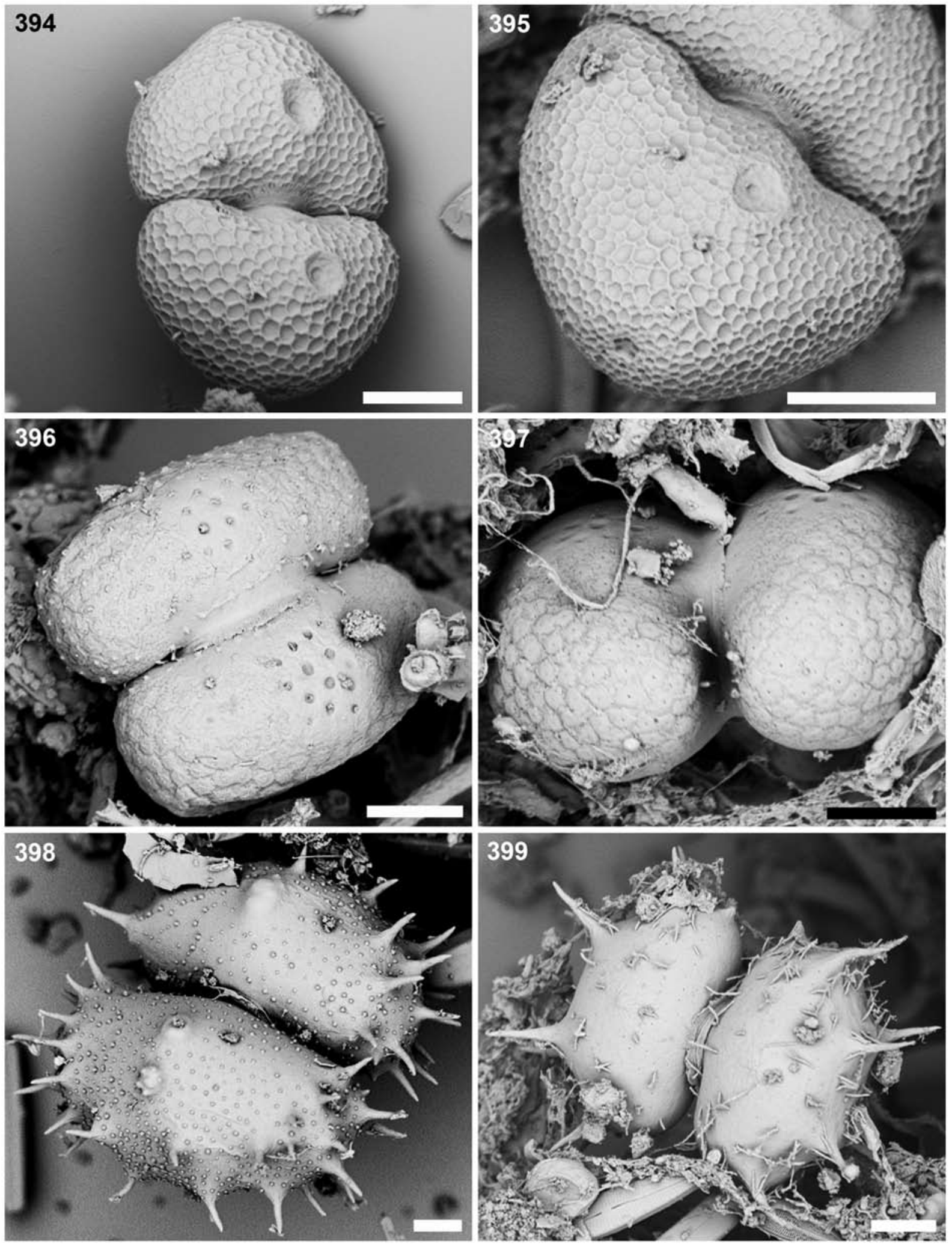

Figs 394-399. (394-395) Cosmarium variolatum var. cataractarum; (396-397) C. varsoviense, (396) cell with collapsed apices; (398) Xanthidium aculeatum; (399) X. cristatum. Scale bar $10 \mu \mathrm{m}$. 

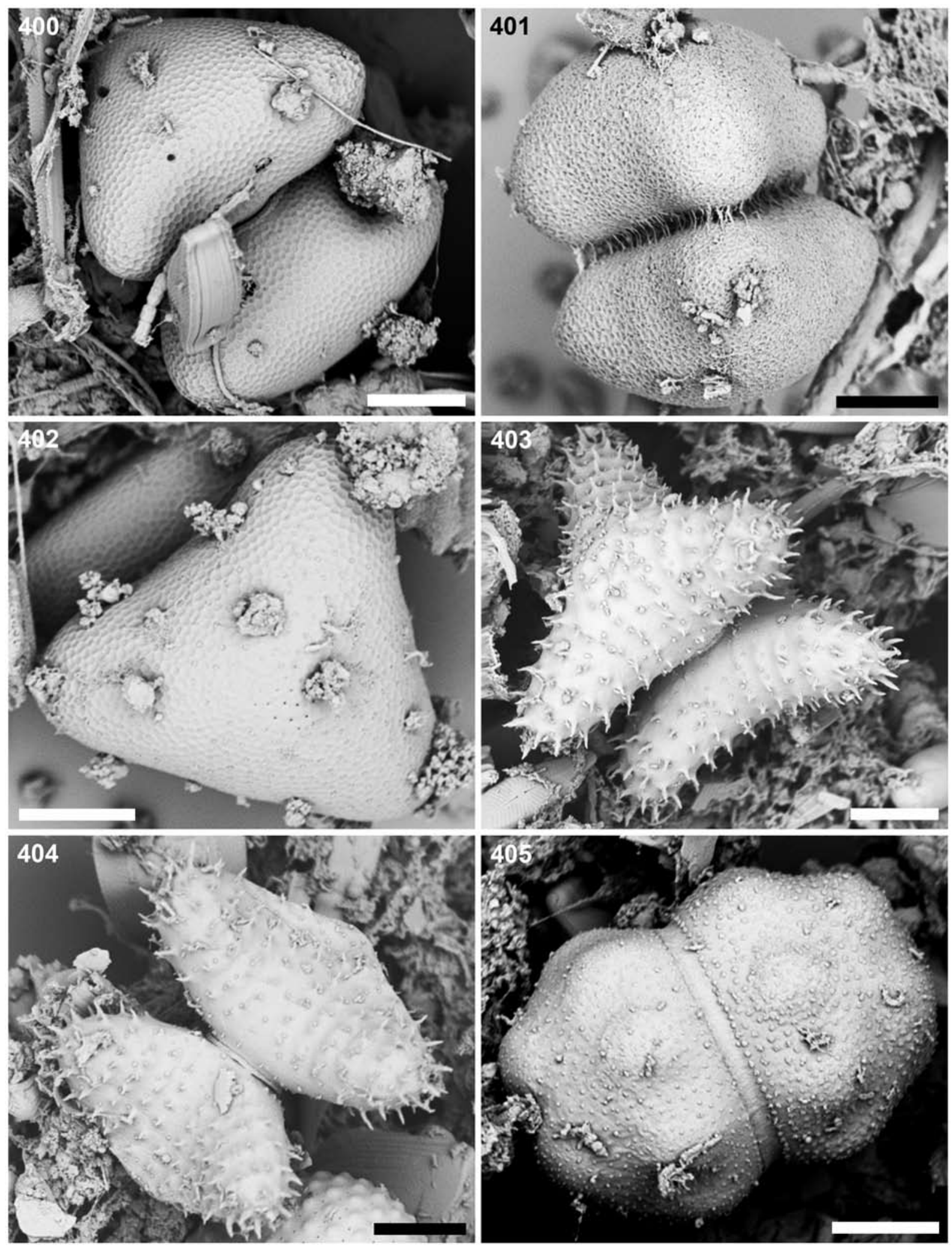

Figs 400-405. (400-402) Staurastrum crassangulatum, (402) apical view; (403-404) St. erasum; (405) St. habeebense. Scale bar $10 \mu \mathrm{m}$. 

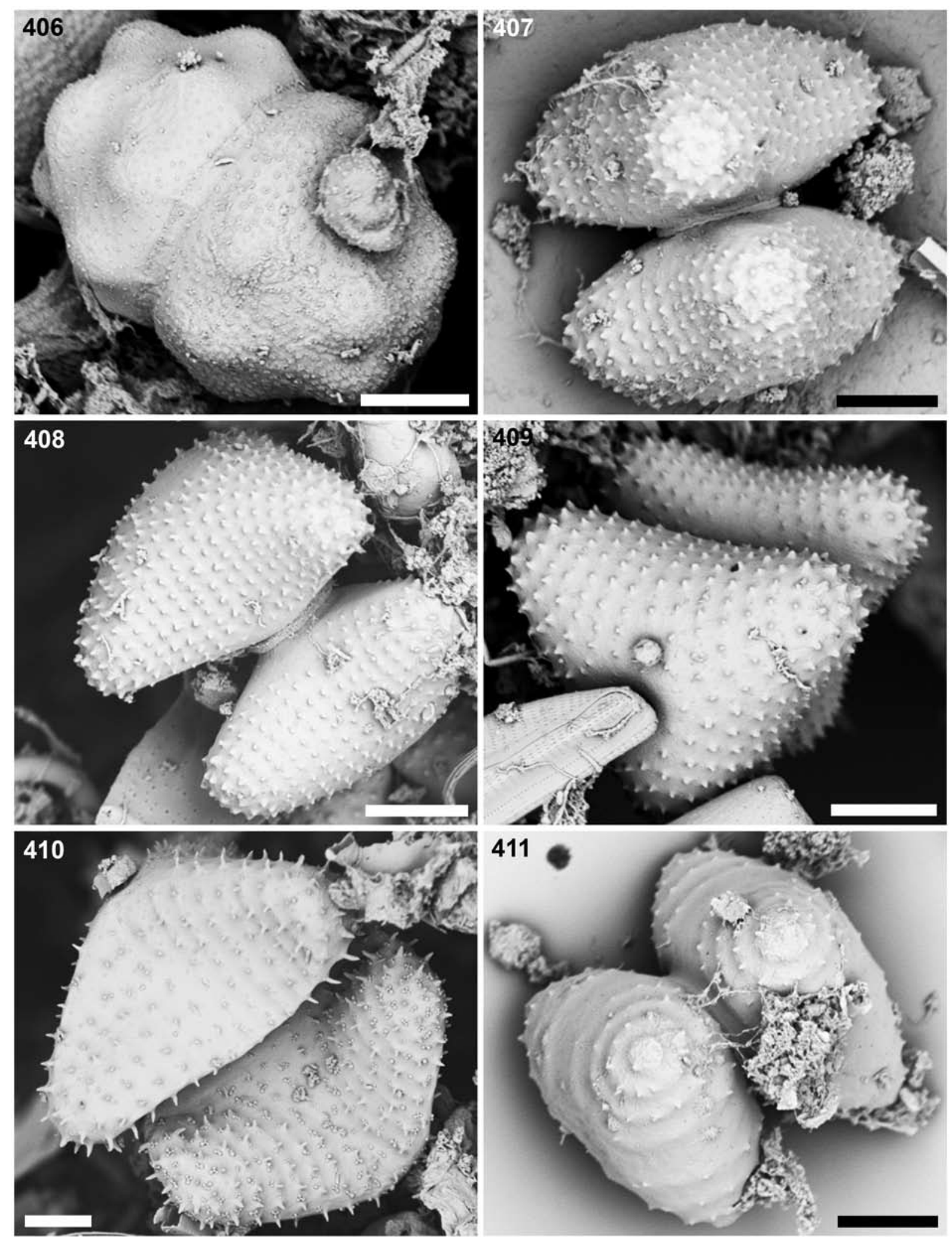

Figs 406-411. (406) Staurastrum habeebense; (407-409) St. lapponicum; (410) St. trapezicum. (411) St. varians. Scale bar $10 \mu \mathrm{m}$. 


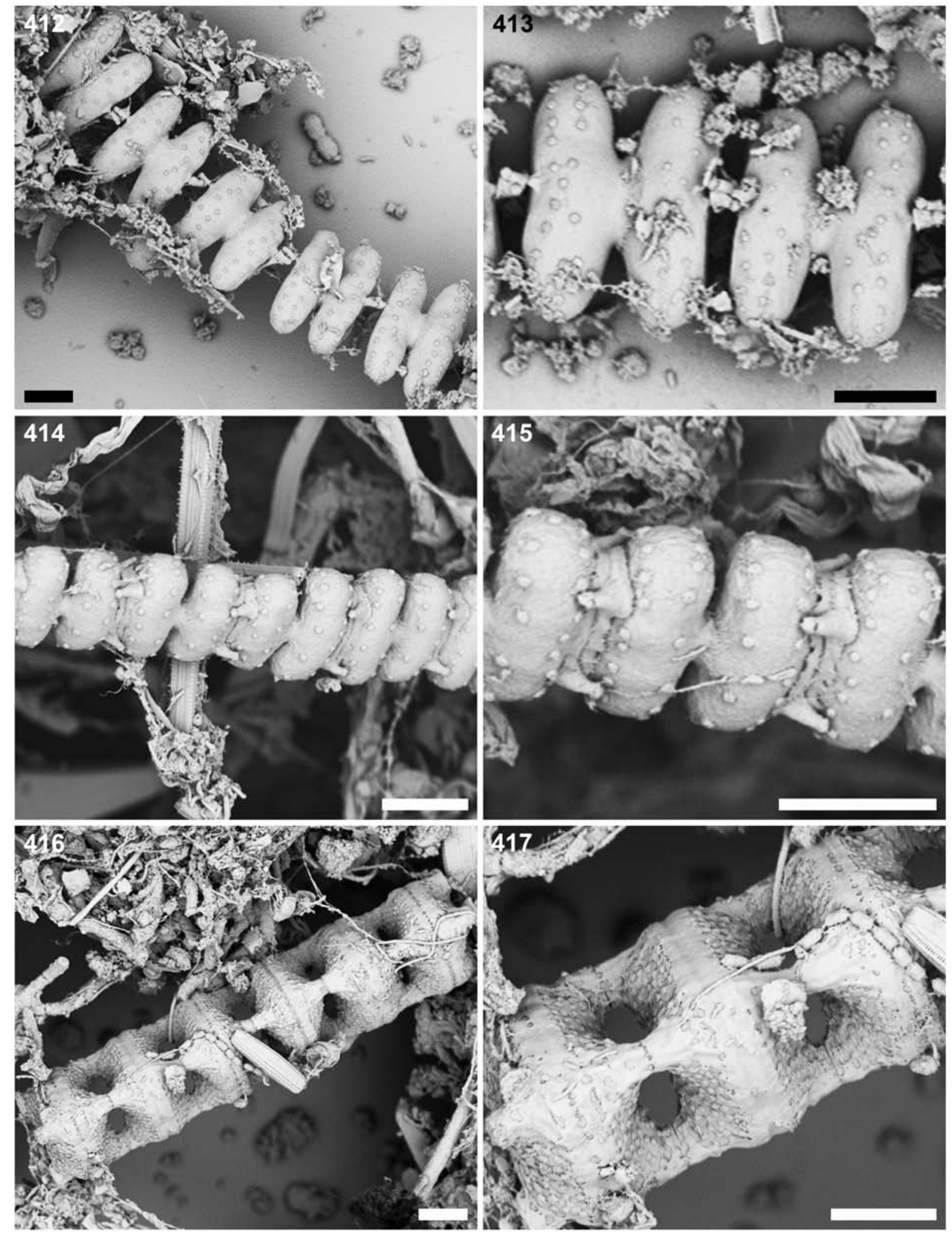

Figs 412-417. (412-413) Sphaerozosma aubertianum; (414-415) Sph. filiforme; (416-417) Desmidium baileyi var. caelatum. Scale bar $10 \mu \mathrm{m}$. 
Table 1. List of all taxa found with their indicative notations [(TRPH) Trophy, (oli) oligotrophic, (mes) mesotrophic, (eu) eutrophic; (ACID) Acidity, (aci) acidic, (neu) neutral, (alk) alkalic; (LF) life form, (ben) benthic, (atm) atmophytic, (pla) planktonic; (R) rarity within the Czech Republic; (S) ecological sensitivity. For details see Introduction].

\begin{tabular}{|c|c|c|c|c|c|}
\hline & TRPH & ACID & $\mathbf{L F}$ & $\mathbf{R}$ & $\mathbf{S}$ \\
\hline Actinotaenium cruciferum (DE BARY) TEILING & oli & aci & ben-atm & 3 & \\
\hline Actinotaenium cucurbita (RALFS) TeILING & oli & aci & ben-atm & & 1 \\
\hline Actinotaenium curtum (RALfs) TeILING & mes-oli & aci-neu & atm-ben & 1 & \\
\hline Actinotaenium diplosporum (P.Lundell) TeILING & mes-oli & aci & ben-atm & 1 & 1 \\
\hline Actinotaenium diplosporum var. americanum (W. et G.S.West) TEILING & mes & aci & ben-atm & 2 & \\
\hline Actinotaenium inconspicuum (W. et G.S.WeSt) TeILING & oli-mes & aci & ben-atm & 2 & \\
\hline Actinotaenium inconspicuum var. curvatum Kouwets & oli-mes & aci & ben-atm & 3 & \\
\hline Actinotaenium kriegeri (Messik.) Kouwets & oli-mes & aci & ben-atm & 3 & \\
\hline Actinotaenium obcuneatum (W.West) TeILING & oli & aci & ben-atm & 3 & \\
\hline Actinotaenium perminutum (G.S.WeSt) TEILING & oli-mes & aci & ben-atm & 3 & 3 \\
\hline Actinotaenium silvae - nigrae (RABANus) Kouwets et COESEL & oli & aci & ben-atm & 1 & 2 \\
\hline $\begin{array}{l}\text { Actinotaenium silvae - nigrae var. parallelum (WilLi KrIEG.) Kouwets et } \\
\text { COESEL }\end{array}$ & oli & aci & ben-atm & 2 & 2 \\
\hline Actinotaenium subsparsepunctatum (GRÖNBLAD) COESEL & oli & aci & ben-atm & 3 & \\
\hline Actinotaenium turgidum (RALFs) TEILING & mes & aci & ben & & 2 \\
\hline Bambusina brebissonii KüTz. & oli & aci & ben & & 2 \\
\hline Closterium abruptum W.WEST & mes-oli & aci & ben-atm & 1 & \\
\hline Closterium acerosum RALFS & eu-mes & alk-aci & ben & & \\
\hline Closterium acerosum var. elongatum BRÉB. & eu-mes & alk-aci & ben-pla & & \\
\hline Closterium acerosum var. minus HANTZSCH & eu-mes & aci-alk & ben & & \\
\hline Closterium aciculare T.WEST & eu-mes & alk-neu & pla & 1 & \\
\hline Closterium acutum RALFS & oli-eu & aci-alk & ben-pla & & \\
\hline Closterium acutum var. variabile (Lemmerm.) WiLLi Krieg. & eu-mes & neu-alk & pla & & \\
\hline Closterium angustatum RALFS & mes-oli & aci & ben & 1 & 3 \\
\hline Closterium angustatum var. sculptum (RACIB.) RŮŽIČKA & mes-oli & aci & ben & 3 & 3 \\
\hline Closterium archerianum CLEVE & mes & aci & ben & 2 & 2 \\
\hline Closterium archerianum var. pseudocynthia RŮžıčKA & mes & aci-neu & ben & 2 & 2 \\
\hline Closterium attenuatum RALFS & mes & aci & ben & 1 & 2 \\
\hline Closterium baillyanum (RALFs) BRÉB. & oli-mes & aci & ben & 1 & 2 \\
\hline Closterium baillyanum var. alpinum (VIRET) GRÖNBLAD & oli-mes & aci & ben & 1 & 2 \\
\hline Closterium braunii REINSCH & mes & aci & ben & 3 & 3 \\
\hline Closterium calosporum WITTR. & mes & aci & ben & 1 & 1 \\
\hline Closterium calosporum var. brasiliense BøRGES. & mes-oli & aci & ben & 3 & 3 \\
\hline Closterium calosporum var. maius (W. et G.S.WeSt) WiLLi Krieg. & mes-eu & neu & ben & 3 & \\
\hline Closterium closterioides (RALFS) A.LouIs et PeETERS & mes-oli & aci & ben & 3 & 3 \\
\hline Closterium closterioides var. intermedium (J.RoY et BISSET) RŮžIČKA & mes-oli & aci & ben & 3 & 3 \\
\hline Closterium cornu RALFS & oli-mes & aci & ben-atm & & \\
\hline Closterium cornu var. upsaliense NORDST. & oli-mes & aci & ben-atm & 2 & \\
\hline Closterium costatum RALFS & mes & aci & ben & 1 & 2 \\
\hline Closterium costatum var. borgei (WILLI. KRIEG.) RƯŽIČKA & mes & aci & ben & 1 & 2 \\
\hline Closterium cynthia DE Noт. & mes & aci & ben & 1 & 2 \\
\hline
\end{tabular}


Table 1 Cont.

\begin{tabular}{|c|c|c|c|c|c|}
\hline & TRPH & ACID & $\mathbf{L F}$ & $\mathbf{R}$ & $\mathbf{S}$ \\
\hline Closterium delpontei (G.A.KLEBS) Wolle & mes & aci & ben & 3 & 3 \\
\hline Closterium dianae RALFS & mes & aci & ben & & 1 \\
\hline Closterium dianae var. arcuatum (BRÉB.) RABENH. & mes & aci & ben & 1 & 2 \\
\hline Closterium dianae var. minus HIERON. & mes & aci & ben & 1 & 1 \\
\hline Closterium dianae var. pseudodianae (J.Roy) WiLli Krieg. & mes & aci & ben & 3 & 2 \\
\hline Closterium dianae var. rectius (NoRdST.) DE TONI & mes & aci & ben & 3 & 2 \\
\hline Closterium didymotocum RALFS & mes & aci & ben & 2 & 3 \\
\hline Closterium directum $\mathrm{W}$.ARCHER & oli-mes & aci & ben & 2 & 2 \\
\hline Closterium ehrenbergii RALFS & eu-mes & alk-aci & ben & & \\
\hline Closterium exile W. et G.S.WEST & oli & aci-neu & ben-atm & 3 & \\
\hline Closterium gracile RALFS & mes-oli & aci & ben & & 2 \\
\hline Closterium gracile var. elongatum W. et G.S.WEST & mes & aci & ben & 2 & 2 \\
\hline Closterium idiosporum W. et G.S.WEST & mes-eu & aci-neu & ben & 1 & \\
\hline Closterium incurvum BRÉB. & mes-eu & aci-alk & ben & & \\
\hline Closterium intermedium RALFS & mes-oli & aci & ben & & 1 \\
\hline Closterium juncidum RALFS & oli-mes & aci & ben & 1 & 2 \\
\hline Closterium juncidum var. brevius (RABENH.) J.RoY & oli-mes & aci & ben & 1 & 2 \\
\hline Closterium kuetzingii BRÉB. & mes & aci-neu & ben & & \\
\hline Closterium leibleinii RALFS var. boergesenii (SCHMIDLE) SKVORTSOV & eu & alk-neu & ben & 1 & \\
\hline Closterium limneticum LEMMERM. & $\mathrm{eu}$ & alk-neu & pla & & \\
\hline Closterium limneticum var. fallax RŮžIČKA & $\mathrm{eu}$ & alk-neu & pla & 1 & \\
\hline Closterium limneticum var. tenue LEMMERM. & eu & alk-neu & pla & & \\
\hline Closterium lineatum RALFS & mes & aci & ben & 1 & 2 \\
\hline Closterium lineatum var. elongatum (RosA) CROASDALE & mes & aci & ben & 1 & 2 \\
\hline Closterium lineatum var. costatum WolLE & mes & aci & ben & 3 & 2 \\
\hline Closterium littorale F.GAY & eu-mes & alk-neu & ben-pla & 2 & \\
\hline Closterium lunula RALFS & mes & aci & ben & & 1 \\
\hline Closterium moniliferum RALFS & eu-mes & alk-aci & ben & & \\
\hline Closterium navicula (BRÉB.) LÜTKEM. & mes-oli & aci & ben & & \\
\hline Closterium nematodes JOSHUA var. proboscideum W.B.TURNER & mes & aci & ben & 3 & 2 \\
\hline Closterium parvulum NäGELI & mes & aci-neu & ben & & \\
\hline Closterium praelongum BRÉB. & mes-eu & aci-alk & ben-pla & & \\
\hline Closterium praelongum var. brevius (NoRDST.) WILLI KRIEG. & mes-eu & aci-alk & ben & & \\
\hline Closterium pritchardianum W.ARCHER & mes-eu & aci-neu & ben-pla & & \\
\hline Closterium pronum BRÉB. & oli-mes & aci & ben & & 1 \\
\hline Closterium pseudolunula BORGE & mes-eu & aci-neu & ben & 2 & \\
\hline Closterium pseudopygmaeum KouwETs & oli-mes & aci & ben-atm & 3 & \\
\hline Closterium pusillum HANTZSCH & oli & aci & atm-ben & 3 & \\
\hline Closterium ralfsii RALFS & mes & aci & ben & 3 & 2 \\
\hline Closterium ralfsii var. hybridum RABENH. & mes & aci & ben & 1 & 2 \\
\hline Closterium regulare BRÉB. & mes & aci-alk & ben & 2 & 2 \\
\hline Closterium rostratum RALFS & mes & aci & ben-atm & & \\
\hline Closterium setaceum RALFS & oli-mes & aci & ben & 1 & 2 \\
\hline
\end{tabular}


Table 1 Cont.

\begin{tabular}{|c|c|c|c|c|c|}
\hline & TRPH & ACID & LF & $\mathbf{R}$ & $\mathbf{S}$ \\
\hline Closterium strigosum BRÉB. & eu-mes & alk-neu & pla-ben & 2 & \\
\hline Closterium strigosum var. elegans (G.S.WeST) WiLLI KRIEG. & eu-mes & neu & ben & 2 & \\
\hline Closterium striolatum RALFS & oli & aci & ben & & \\
\hline Closterium sublaterale Růžička & mes & aci-neu & ben & 1 & \\
\hline Closterium submoniliferum WoRON. & eu-mes & alk-aci & ben & & \\
\hline Closterium subulatum (KÜTZ.) BRÉB. & eu-mes & neu-alk & ben & 3 & 1 \\
\hline Closterium tortitaenoides COESEL & oli & aci & ben & 3 & 2 \\
\hline Closterium tumidulum F.GAY & eu & alk-neu & ben-pla & & \\
\hline Closterium tumidum JoHNs. & oli & aci & ben-atm & 2 & \\
\hline Closterium tumidum var. nylandicum GRÖNBLAD & oli & aci & ben-atm & 3 & \\
\hline Closterium turgidum RALFS & mes & aci & ben & 1 & 2 \\
\hline Closterium turgidum var. giganteum (NORDST.) DE TONI & mes & aci-neu & ben-pla & 3 & 2 \\
\hline Closterium venus RALFS & eu-mes & neu-alk & ben-pla & & \\
\hline Cosmarium abbreviatum RACIB. & mes-eu & neu-alk & ben-pla & 3 & \\
\hline Cosmarium amoenum RALFS & oli-mes & aci & ben & 1 & 2 \\
\hline Cosmarium anceps P.LuNDELL & oli & aci & atm-ben & 1 & \\
\hline Cosmarium angulare JoHNs. & $\mathrm{eu}$ & alk & ben & 3 & 2 \\
\hline Cosmarium angulosum BRÉB. & mes & aci & ben & 2 & 3 \\
\hline Cosmarium angulosum var. concinnum (RABENH.) W. et G.S.WeST & mes & aci & ben & 3 & 3 \\
\hline Cosmarium basiornatum (GRÖNBLAD) COESEL & oli-mes & aci & atm-ben & 2 & \\
\hline Cosmarium berryense KouweTs & eu & alk & ben & 3 & 2 \\
\hline Cosmarium bioculatum RALFS & mes & aci & ben & & \\
\hline Cosmarium bioculatum var. depressum (SCHAARSCHM.) SCHMIDLE & mes-eu & aci-alk & ben-pla & & \\
\hline Cosmarium bireme NORDST. & mes & aci & ben & 3 & 3 \\
\hline Cosmarium biretum RALFS & $\mathrm{eu}$ & alk & ben-pla & 2 & \\
\hline Cosmarium biretum var. trigibberum NORDST. & eu & alk & ben-pla & 2 & \\
\hline Cosmarium blytii WILLE & mes-oli & aci & ben & 3 & 3 \\
\hline Cosmarium blytii var. novae - sylvae W. et G.S.WEST & mes-oli & aci & ben & 1 & 2 \\
\hline Cosmarium boeckii WILLE & mes-eu & aci-alk & ben & & 1 \\
\hline Cosmarium boitierense Kouwets & mes-eu & aci-neu & ben & 3 & 2 \\
\hline Cosmarium botrytis RALFS & mes-eu & aci-neu & ben & 2 & \\
\hline Cosmarium botrytis var. gemmiferum (BRÉB.) NORDST. & mes-eu & neu-aci & ben & 2 & \\
\hline Cosmarium botrytis var. mediolaeve W.WEST & mes-eu & aci-neu & ben & 1 & \\
\hline Cosmarium botrytis var. tumidum WoLLE & mes-eu & neu & ben & 1 & 2 \\
\hline Cosmarium brebissonii RALFS & mes-oli & aci & ben & 3 & 2 \\
\hline Cosmarium caelatum RALFS & oli-mes & aci & atm-ben & & \\
\hline Cosmarium carinthiacum LÜTKEM. & oli-mes & aci & ben & 3 & 3 \\
\hline Cosmarium ceratophorum LÜTKEM. & mes & aci & ben & 3 & \\
\hline Cosmarium commisurale RALFs var. acutum BRÉB. & mes & aci & ben & 3 & \\
\hline Cosmarium connatum RALFS & mes & aci & ben & 1 & 2 \\
\hline Comarium conspersum RALFS var. latum (BRÉB.) W. et G.S.WeST & mes & aci & ben & 2 & 3 \\
\hline Cosmarium contractum KIRCHN. & mes-oli & aci & ben & 2 & 3 \\
\hline Cosmarium contractum var. ellipsoideum (ELFVING) W. et G.S. WeST & mes-oli & aci & ben & 2 & 3 \\
\hline
\end{tabular}


Table 1 Cont.

\begin{tabular}{|c|c|c|c|c|c|}
\hline & TRPH & ACID & $\mathbf{L F}$ & $\mathbf{R}$ & $\mathbf{S}$ \\
\hline Cosmarium contractum var. minutum (DeLPONTE) COESEL & mes-eu & aci-alk & ben & & \\
\hline $\begin{array}{l}\text { Cosmarium contractum var. retusum (W. ET G.S.WEST) WILLI KRIEG. et GER- } \\
\text { LOFF }\end{array}$ & mes & aci & ben & 3 & 3 \\
\hline Cosmarium contractum var. rotundatum BORGE & mes-oli & aci & ben & 3 & 3 \\
\hline Cosmarium crenatum RALFS & oli-mes & aci & atm-ben & 1 & \\
\hline Cosmarium crenatum var. bicrenatum NORDST. & oli-mes & aci & atm-ben & 2 & \\
\hline Cosmarium crenulatum NäGELI & mes & aci-neu & ben & 1 & 1 \\
\hline Cosmarium cucumis RALFS & mes & aci & ben & 2 & 3 \\
\hline Cosmarium cyclicum P.LuNDELL & mes-oli & aci & atm-ben & 2 & \\
\hline Cosmarium cyclicum var. arcticum NORDST. & mes-oli & aci & atm-ben & 2 & \\
\hline Cosmarium davidsonii J.RoY et BISSET & oli & aci & atm-ben & 3 & \\
\hline Cosmarium debaryi W.ARCHER & mes & aci & ben & 1 & 2 \\
\hline Cosmarium decedens (REINSCH) RACIB. & oli & aci & atm-ben & 3 & \\
\hline Cosmarium decedens var. apertum Willi KrIEg. et GerlofF & oli & aci & atm-ben & 3 & \\
\hline Cosmarium decedens var. minutum (Gutw.) Willi Krieg. et Gerloff & oli-mes & aci & atm-ben & 3 & \\
\hline Cosmarium denboeri MeEsters et COESEL & eu & neu-alk & pla-ben & 2 & \\
\hline Cosmarium dentiferum NoRDst. var. alpinum MESSIK. & oli & aci & ben-atm & 3 & \\
\hline Cosmarium depressum (NägeLI) P.Lundell & mes & aci-neu & ben & 1 & 2 \\
\hline Cosmarium depressum var. planctonicum REVERDIN & mes & neu & pla-ben & 2 & \\
\hline Cosmarium dickii COESEL & mes & aci-neu & ben & 1 & 2 \\
\hline Cosmarium didymoprotupsum W. et G.S. WeST & eu-mes & neu-eu & ben & 3 & 2 \\
\hline Cosmarium difficile LÜTKEM. & mes & aci & ben & & 1 \\
\hline Cosmarium dilatatum JäRNEFELT et GRÖNBLAD & eu-mes & neu & pla & 3 & \\
\hline Cosmarium eichlerianum (GRÖNBLAD) MESSIK. & mes & aci & ben & 3 & 3 \\
\hline Cosmarium fastidiosum W. et G.S. WeST & mes & aci & ben & 3 & 3 \\
\hline Cosmarium fontigenum NoRDST. & mes & aci-neu & ben & 3 & 2 \\
\hline Cosmarium formosulum HoFF & eu-mes & aci-alk & ben-pla & & \\
\hline Cosmarium furcatospermum W. et G.S. WEST & mes-eu & neu & ben & 3 & \\
\hline Cosmarium galeritum NoRDST. & oli-mes & aci & ben-atm & 3 & \\
\hline Cosmarium garrolense J.RoY et BISSET & oli-mes & aci & ben-atm & 3 & \\
\hline Cosmarium gibberulum LÜTKEM. & mes & neu-aci & ben & 2 & 2 \\
\hline Cosmarium goniodes W. et G.S. WeST var. subturgidum W. et G.S. WeST & mes-oli & aci & ben & 1 & 2 \\
\hline Cosmarium granatum RALFS & mes-eu & neu-aci & ben & & \\
\hline Cosmarium holmiense P.LUNDELL & mes & aci & ben & 3 & \\
\hline Cosmarium holmiense var. hibernicum (W.WEST) SCHMIDLE & mes-oli & aci & ben-atm & 3 & \\
\hline Cosmarium holmiense var. integrum P.LUNDELL & mes-oli & aci & atm-ben & & \\
\hline Cosmarium homalodermum NORDST. & oli-mes & aci & ben-atm & 3 & \\
\hline Cosmarium hornavanense GuTw. & mes-oli & aci & ben-atm & 3 & \\
\hline Cosmarium hornavanense var. dubovianum (LÜTKEM.) RỦŽIČKA & mes-eu & neu-alk & ben & 2 & \\
\hline Cosmarium humile (F.GAY) NORDST. & mes-eu & aci-alk & ben & & 2 \\
\hline Cosmarium impressulum ELFVING & mes & aci-neu & ben & & \\
\hline Cosmarium jaoi Kouwets & eu & alk-neu & ben & 3 & 2 \\
\hline Cosmarium kirchneri BøRGES. & mes & aci & ben & 3 & 3 \\
\hline
\end{tabular}


Table 1 Cont.

\begin{tabular}{|c|c|c|c|c|c|}
\hline & TRPH & ACID & LF & $\mathbf{R}$ & $\mathbf{S}$ \\
\hline Cosmarium kjellmanii $\mathrm{W}_{\mathrm{ILLE}}$ & eu & alk-neu & ben-pla & 2 & \\
\hline Cosmarium klebsii Gutw. & mes-eu & aci-alk & ben & 3 & 2 \\
\hline Cosmarium laeve RABENH. & eu-mes & alk-aci & ben-pla & & \\
\hline Cosmarium laeve var. octangulare (WILLE) W. et G.S. WeST & eu-mes & alk-aci & ben-pla & & \\
\hline Cosmarium lagerheimii Gutw. & mes-eu & aci-neu & ben & 3 & 2 \\
\hline Cosmarium limnophilum SCHMIDLE & mes-eu & aci-neu & ben & 3 & 3 \\
\hline Cosmarium margaritatum (P.LuNDELL) J.RoY et BISSET & mes & aci & ben & 3 & 3 \\
\hline Cosmarium margaritiferum RALFS & mes & aci & ben & 1 & 2 \\
\hline Cosmarium medioretusum COESEL & mes & aci & ben & 3 & 3 \\
\hline Cosmarium meneghinii RALFS & mes-eu & neu-aci & ben & 1 & \\
\hline Cosmarium microsphinctum NORDST. & oli-mes & aci & atm-ben & 3 & \\
\hline Cosmarium microsphinctum var. crispulum NORDST. & oli-mes & aci & atm-ben & 3 & \\
\hline Cosmarium moniliforme RALFS var. panduriforme (HEIMERL) SCHMIDLE & mes & aci & ben & 2 & 2 \\
\hline Cosmarium netzerianum SCHMIDLE & oli & aci & ben-atm & 3 & \\
\hline $\begin{array}{l}\text { Cosmarium norimbergense REINSCH var. depressum (W. et G.S.WeSt) WILLI } \\
\text { KRIEG. et GERLOFF }\end{array}$ & oli-mes & aci-neu & ben & 3 & \\
\hline Cosmarium notabile BRÉB. & mes-oli & aci-neu & atm-ben & & \\
\hline Cosmarium notatum (GRÖNBLAD) COESEL & mes & aci & ben & 3 & 3 \\
\hline Cosmarium novae - semliae WiLle var. granulatum (SCHMIDLE) SCHMidLE & oli-mes & aci & ben & 3 & \\
\hline Cosmarium obliquum NoRDST. & oli & aci & ben-atm & 2 & \\
\hline Cosmarium obsoletum (HaNtzsch) ReINSCH & mes-oli & aci & ben & 3 & 3 \\
\hline Cosmarium obtusatum SCHMIDLE & mes-eu & neu-alk & ben & & \\
\hline Cosmarium ocellatum B.EICHLER et GuTw. & mes & aci & ben & 3 & 2 \\
\hline Cosmarium ocellatum var. notatum (Nordst.) WiLli KrIEg. et Gerloff & mes & aci & ben & 3 & 3 \\
\hline Cosmarium ochthodes NORDST. & mes & aci & ben & 1 & 1 \\
\hline Cosmarium ordinatum (BøRGES.) W. et G.S.WEST & mes-oli & aci & ben & 3 & 3 \\
\hline Cosmarium ornatulum COESEL & eu & alk & pla & 1 & \\
\hline Cosmarium ornatulum var. depressum COESEL & eu & alk & pla & 3 & \\
\hline Cosmarium ornatum RALFs & mes-oli & aci & ben & 1 & 2 \\
\hline Cosmarium orthopunctulatum SCHMIDLE & oli & aci & ben-atm & 1 & \\
\hline Cosmarium ovale RALFs & mes & aci & ben & 3 & 3 \\
\hline Cosmarium pachydermum P.LUNDELL & mes & aci & ben & 1 & 2 \\
\hline Cosmarium pachydermum var. aethiopicum W. et G.S.WEST & mes & aci & ben & 2 & 2 \\
\hline Cosmarium paragranatoides SKUנA & mes & aci & ben & 3 & 3 \\
\hline Cosmarium parvulum BRÉB. var. undulatum SCHMIDLE & oli & aci & atm-ben & 3 & \\
\hline Cosmarium paucigranulatum BORGE & mes & neu & ben & 3 & \\
\hline Cosmarium perforatum P.LundeLL & mes & aci & ben & 3 & 3 \\
\hline Cosmarium pericymatium NORDST. & oli & neu-aci & atm-ben & 2 & \\
\hline Cosmarium pericymatium var. corrugatum $\mathrm{B}$ ROOK & oli & neu & atm-ben & 3 & \\
\hline Cosmarium pericymatium var. notabiliforme INSAM et KRIEGER & oli & neu & atm-ben & 3 & \\
\hline Cosmarium phaseolus RALFS & mes & aci & ben & 3 & \\
\hline Cosmarium phaseolus var. elevatum NORDST. & mes & aci & ben & 3 & 2 \\
\hline Cosmarium pokornyanum (GRUNOw) W. et G.S.WEST & mes & aci & ben-atm & 3 & \\
\hline
\end{tabular}


Table 1 Cont.

\begin{tabular}{|c|c|c|c|c|c|}
\hline & TRPH & ACID & $\mathbf{L F}$ & $\mathbf{R}$ & $\mathbf{S}$ \\
\hline Cosmarium polygonum (NÄGELI) W.ARCHER var. depressum MESSIK. & mes & aci-neu & ben & & 1 \\
\hline Cosmarium portianum W.ARCHER & mes & aci-neu & ben & 1 & 2 \\
\hline Cosmarium praemorsum BRÉB. & mes-eu & neu & ben & 3 & 1 \\
\hline Cosmarium prominulum RACIB. var. subundulatum W. et G.S.WEST & oli-mes & aci & ben & 3 & 3 \\
\hline Cosmarium protractum (NÄGELI) DE BARY & eu & alk & ben & 3 & 2 \\
\hline Cosmarium pseudoexiguum RACIB. & mes & aci & ben & 3 & 2 \\
\hline Cosmarium pseudoinsigne PrescotT & eu-mes & alk-neu & ben & 3 & 2 \\
\hline Cosmarium pseudonitidulum NoRDST. var. validum W. et G.S.WEST & oli & aci-neu & ben-atm & 3 & \\
\hline Cosmarium pseudoornatum B.EICHLER et GuTw. & mes & aci & ben & 2 & 2 \\
\hline Cosmarium pseudoprotuberans KIRCHN. & mes & aci & ben & 3 & 3 \\
\hline Cosmarium pseudoprotuberans var. sulcatum (NoRDST.) COESEL & mes & aci & ben & 3 & 3 \\
\hline Cosmarium pseudopyramidatum P.LUNDELL & oli-mes & aci & ben & 2 & 2 \\
\hline Cosmarium pseudoretusum F.DuCELL & mes & aci & ben & 3 & 3 \\
\hline Cosmarium pseudowembaerense KouWETs & $\mathrm{eu}$ & alk & pla-ben & 3 & \\
\hline Cosmarium punctulatum BRÉB. var. subpunctulatum (NoRDST.) BøRGES. & mes-eu & aci-alk & ben & & \\
\hline Cosmarium pygmaeum W.ARCHER & oli & aci & ben & 2 & 2 \\
\hline Cosmarium pyramidatum RALFS & oli-mes & aci & ben & 2 & 2 \\
\hline Cosmarium pyramidatum var. stenonotum (NORDST.) KLEBS & oli-mes & aci & ben & 3 & 2 \\
\hline Cosmarium quadratulum var. boldtii (Messik.) Willi KRIEG. et GerlofF & mes & aci & ben & 1 & 2 \\
\hline Cosmarium quadratum RALFS & mes & aci & ben & & \\
\hline Cosmarium quadrum P.LuNDELL & mes & aci & ben & 1 & 3 \\
\hline Cosmarium quadrum var. sublatum (NoRDST.) W. et G.S.WEST & mes & aci & ben & 3 & 3 \\
\hline Cosmarium ralfsii RALFs & oli & aci & ben & 3 & 3 \\
\hline Cosmarium ralfsii var. montanum RACIB. & oli & aci & ben & 3 & 3 \\
\hline Cosmarium rectangulare GRUNOW & mes & aci & ben & 2 & 2 \\
\hline Cosmarium regnellii WILLE & mes-eu & aci-alk & ben & & \\
\hline Cosmarium regnesii $\mathrm{REINSCH}$ & mes & aci & ben & 2 & 2 \\
\hline Cosmarium reniforme (RALFS) W.ARCHER & eu-mes & aci-alk & ben & & \\
\hline Cosmarium reniforme var. compressum NORDST. & eu-mes & aci-alk & ben & & \\
\hline Cosmarium retusum (PERTY) RABENH. & mes & aci & ben & 3 & 3 \\
\hline Cosmarium sexnotatum GuTw. var. bipunctatum (Wolosz.) COESEL & mes & aci & ben & 3 & 3 \\
\hline Cosmarium sexnotatum var. tristriatum (LÜTKEM.) SCHMIDLE & oli-mes & aci & ben & 3 & 3 \\
\hline Cosmarium simplicius (W. et G.S.WeST) GRÖNBLAD & mes-oli & aci & atm-ben & 3 & 2 \\
\hline Cosmarium sinostegos SCHAARSCHM. var. obtusius Gutw. & mes & aci & ben & 3 & 2 \\
\hline Cosmarium speciosum P.LundeLL & oli-mes & aci & atm-ben & 3 & \\
\hline Cosmarium speciosum var. simplex NORDST. & oli-mes & aci & atm-ben & 1 & \\
\hline Cosmarium speciosum var. tumidum $\mathrm{SCHMIDLE}$ & oli-mes & aci & atm-ben & 3 & \\
\hline Cosmarium sphagnicolum W. et G.S.WEST & oli & aci & ben & 3 & 2 \\
\hline Cosmarium sphyrelatum COESEL & mes & aci & ben & 3 & 3 \\
\hline Cosmarium sportella BRÉB. var. subnudum W. et G.S.WEST & mes & aci & ben & 1 & \\
\hline Cosmarium striolatum (NÄGELI) W.ARCHER & mes & aci & ben & 3 & 3 \\
\hline Cosmarium subadoxum GRÖNBLAD & mes & aci & ben & 3 & \\
\hline Cosmarium subbroomei SCHMIDLE & eu-mes & neu-alk & ben & 3 & \\
\hline Cosmarium subbroomei f. isthmochondrum COESEL & eu-mes & neu-alk & ben & 3 & 2 \\
\hline
\end{tabular}


Table 1 Cont.

\begin{tabular}{|c|c|c|c|c|c|}
\hline & TRPH & ACID & $\mathbf{L F}$ & $\mathbf{R}$ & $\mathbf{S}$ \\
\hline Cosmarium subcostatum NoRDST. & mes & neu & ben & 3 & \\
\hline Cosmarium subcostatum var. minus (W. et G.S.WeSt) KURT FöRst. & mes & aci-alk & ben & & \\
\hline Cosmarium subcrenatum HANTZSCH & mes & aci & ben-atm & 3 & \\
\hline Cosmarium subcucumis SCHMIDLE & mes & aci & ben & & \\
\hline Cosmarium subgranatum (NoRDST.) LÜTKEM. & mes-eu & aci-alk & ben & & \\
\hline Cosmarium subgranatum var. borgei WILLI KRIEG. & mes-eu & aci-alk & ben & & \\
\hline Cosmarium subprotumidum NoRDST. & eu-mes & alk-aci & ben & 1 & 2 \\
\hline Cosmarium subprotumidum var. pyramidale COESEL & mes-eu & aci-neu & ben & 3 & 2 \\
\hline Cosmarium subquadrans W. et G.S.WeSt var. minor Symoens & oli & aci & ben & 3 & 3 \\
\hline Cosmarium subspeciosum NoRDST. & mes & aci & ben & 3 & 2 \\
\hline Cosmarium subspeciosum var. transiens MESsIK. & oli-mes & aci & ben-atm & 1 & \\
\hline Cosmarium subtumidum NoRDST. & mes-oli & aci & ben & 2 & 2 \\
\hline Cosmarium subtumidum var. groenbladii CROASDALE & mes & aci & ben & 3 & 3 \\
\hline Cosmarium taxichondriforme B.EICHLER et GuTw. & mes & aci & ben & 3 & 3 \\
\hline Cosmarium tenue W.ARCHER & mes & aci-neu & ben & & \\
\hline Cosmarium tetrachondrum P.Lundell forma & mes & aci & ben & 3 & 3 \\
\hline Cosmarium tetraophthalmum RALFS & mes & aci-neu & ben & & \\
\hline Cosmarium thwaitesii Ralfs var. penioides KleBS & mes & aci-neu & ben & 1 & \\
\hline Cosmarium tinctum RALFS & oli-mes & aci & ben & 1 & 2 \\
\hline Cosmarium tinctum var. subretusum MEssIK. & oli-mes & aci & ben & 2 & 2 \\
\hline Cosmarium trachypleurum P.LundeLl var. minus RACIB. & mes & aci & ben & 3 & 3 \\
\hline Cosmarium truncatellum PERTY & oli & aci & ben & 3 & 3 \\
\hline Cosmarium turpinii BRÉB. var. podolicum GuTw. & mes-eu & aci-alk & ben & 1 & 2 \\
\hline $\begin{array}{l}\text { Cosmarium ungerianum (NäGELI) DE BARY var. subtriplicatum W. et } \\
\text { G.S.WEST }\end{array}$ & mes & aci & ben & 3 & 3 \\
\hline Cosmarium variolatum P.LUNDELL & mes & aci & ben & 3 & 3 \\
\hline Cosmarium variolatum var. cataractarum RACIB. & mes-eu & aci-alk & ben & 3 & 2 \\
\hline Cosmarium varsoviense RACIB. & mes & aci & ben & 2 & 2 \\
\hline Cosmarium vexatum W.WEST & mes-eu & neu-alk & ben & 2 & \\
\hline Cosmarium vexatum var. concavum SCHMIDLE & mes & aci & ben & 3 & \\
\hline Cosmarium vogesiacum LEMAIRE & oli-mes & aci & ben & 3 & \\
\hline Cosmarium wittrockii P.LundelL & eu-mes & neu-alk & ben & 2 & 2 \\
\hline Cosmocladium constrictum W.ARCHER & mes & aci & pla & 3 & \\
\hline Cosmocladium saxonicum J.Roy et BISSET & mes & neu & pla & 3 & \\
\hline Cylindrocystis brebissonii $\mathrm{DE}$ BARY & oli & aci & ben-atm & & \\
\hline Cylindrocystis crassa DE BARY & oli & aci & atm & 3 & \\
\hline Cylindrocystis gracilis I.HIRN & oli & aci & ben-atm & & \\
\hline Desmidium aptogonит Küтz. & mes & aci-neu & ben & 2 & 2 \\
\hline Desmidium baileyi (RALFS) NoRDST. var. caelatum (KIRCHN.) NoRDST. & mes & aci & ben & 3 & 3 \\
\hline Desmidium grevillei (RALFs) DE BARY & mes-oli & aci & ben & 2 & 3 \\
\hline Desmidium swartzii RALFS & mes & aci-neu & ben & & 1 \\
\hline Docidium baculum RALFs & mes-oli & aci & ben & 3 & 3 \\
\hline Euastrum ansatum RALFs & mes-oli & aci & ben & & 1 \\
\hline Euastrum ansatum var. rhomboidale F.DucELL. & mes-oli & aci & ben & 3 & 3 \\
\hline
\end{tabular}


Table 1 Cont.

\begin{tabular}{|c|c|c|c|c|c|}
\hline & TRPH & ACID & $\mathbf{L F}$ & $\mathbf{R}$ & $\mathbf{S}$ \\
\hline Euastrum bidentatum NäGELI & mes & aci-neu & ben & & \\
\hline Euastrum bidentatum var. speciosum (BoLDT) SCHMIDLE & mes & aci-neu & ben & 1 & \\
\hline Euastrum binale RALFS & oli & aci & ben & 3 & \\
\hline Euastrum binale var. gutwinskii (SCHMIDLE) HomFELD & oli & aci & ben & & \\
\hline Euastrum biscrobiculatum (Wolosz.) Coesel & mes & aci & ben & 3 & 3 \\
\hline $\begin{array}{l}\text { Euastrum brevisinuosum (NORDST.) KouwETS var. dissimile (NoRDST.) Kou- } \\
\text { WETS }\end{array}$ & oli & aci & atm-ben & 3 & \\
\hline Euastrum crassicolle P.LundELL & oli-mes & aci & ben-atm & 3 & \\
\hline Euastrum crassum RALFS & oli & aci & ben & 3 & 3 \\
\hline Euastrum denticulatum F.GAY & mes & aci & ben & 1 & 2 \\
\hline Euastrum dubium NÄGELI & oli-mes & aci & ben & 3 & \\
\hline Euastrum dubium var. ornatum Wolosz. & mes & aci & ben & 2 & 2 \\
\hline Euastrum elegans RALFS & mes & aci & ben & 1 & 2 \\
\hline Euastrum gayanum DE TonI & mes-oli & aci & ben & & 1 \\
\hline Euastrum germanicum (SCHMIDLE) WiLLI KRIEG. & eu-mes & aci-alk & ben-pla & 2 & 2 \\
\hline Euastrum humerosum RALFS & oli-mes & aci & ben & & 2 \\
\hline Euastrum humerosum var. affine (RALFS) G.C.WALLICH & oli-mes & aci & ben & 3 & 2 \\
\hline Euastrum insigne RALFS & oli & aci & ben & 2 & 3 \\
\hline Euastrum insulare (WITTR.) J.RoY & mes & aci-neu & ben & 2 & 2 \\
\hline Euastrum luetkemuelleri F.Ducell. var. carniolicum (LÜTKEM.) WiLLI KRIEG. & oli-mes & aci & ben & 3 & 3 \\
\hline Euastrum montanum W. et G.S.WEST & mes-oli & aci & ben & 3 & \\
\hline Euastrum oblongum RALFS & mes & aci & ben & & 2 \\
\hline Euastrum pectinatum RALFS & mes & aci & ben & 1 & 2 \\
\hline Euastrum pinnatum RALFS & mes & aci & ben & 3 & 3 \\
\hline Euastrum pulchellum BRÉB. & mes & aci & ben & 3 & 3 \\
\hline Euastrum subalpinum MEssiк. & oli-mes & aci & ben-atm & 2 & \\
\hline Euastrum subalpinum var. crassum Messik. & oli-mes & aci & ben-atm & 3 & \\
\hline Euastrum turneri W.WeST & mes & aci & ben & 3 & 3 \\
\hline Euastrum verrucosum RALFS & mes & aci & ben & 1 & 2 \\
\hline Euastrum verrucosum var. alatum WoLLE & mes & aci & ben & 1 & 2 \\
\hline Gonatozygon aculeatum HASTINGS & mes & aci & ben & 3 & 3 \\
\hline Gonatozygon brebissonii DE BARY & mes & aci & ben & 1 & 2 \\
\hline Gonatozygon brebissonii var. alpestre RŮŽIČKA & oli-mes & aci & ben-atm & 3 & \\
\hline Gonatozygon kinahanii (W.ARCHER) RABENH. & mes-eu & aci-neu & ben & 1 & 1 \\
\hline Gonatozygon monotaenium DE BARY & mes-eu & aci-neu & ben-pla & 1 & 1 \\
\hline Haplotaenium indentatum Kouwets var. latius Kouwets morpha & oli & aci & ben & 3 & 3 \\
\hline Haplotaenium minutum (RALFS) BANDO & oli & aci & ben & 2 & 3 \\
\hline Haplotaenium rectum (DELPONTE) BANDO & oli-mes & aci & ben & 2 & 3 \\
\hline Hyalotheca dissiliens RALFs & mes & aci-neu & ben & & \\
\hline Hyalotheca dissiliens var. tatrica RACIB. & oli & aci & ben & 2 & 2 \\
\hline Hyalotheca тисоsa RALFS & mes & aci & ben & 2 & 1 \\
\hline Mesotaenium caldariorum (LAGERH.) HANSG. & mes & aci-neu & atm-ben & 3 & \\
\hline Mesotaenium degreyi W.B.TuRnER & oli & aci & atm-ben & 3 & \\
\hline Mesotaenium endlicherianum NäGELI & oli & aci & atm-ben & 2 & \\
\hline
\end{tabular}


Table 1 Cont.

\begin{tabular}{|c|c|c|c|c|c|}
\hline & TRPH & ACID & LF & $\mathbf{R}$ & $\mathbf{S}$ \\
\hline Mesotaenium macrococcum (KüTz.) J.RoY et BISSET & oli & aci & atm & & \\
\hline Mesotaenium macrococcum var. minus (DE BARY) COMPÈRE & oli & aci & atm-ben & 1 & \\
\hline Micrasterias americana RALFS & mes & aci & ben-pla & 1 & 2 \\
\hline Micrasterias apiculata RALFS & mes & aci & ben & 3 & 3 \\
\hline Micrasterias brachyptera P.LUNDELL & mes & aci & ben & 3 & 3 \\
\hline Micrasterias crux - melitensis RALFS & mes & aci-neu & ben-pla & 1 & 2 \\
\hline Micrasterias denticulata RALFS & mes & aci & ben & 3 & 2 \\
\hline Micrasterias denticulata var. angulosa (HANTZSCH) W. et G.S.WEST & mes & aci & ben & 2 & 2 \\
\hline Micrasterias fimbriata RALFS & mes & aci & ben & 2 & 3 \\
\hline Micrasterias furcata RALFS & mes & aci & ben & 3 & 3 \\
\hline Micrasterias jenneri RALFS & oli & aci & ben & 3 & 3 \\
\hline Micrasterias oscitans RALFS & oli & aci & ben & 3 & 3 \\
\hline Micrasterias papillifera RALFS & mes & aci & ben & 1 & 2 \\
\hline Micrasterias papillifera var. pseudomurrayi LAPORTE & mes & aci & ben & 3 & 2 \\
\hline Micrasterias pinnatifida RALFS & mes & aci & ben & 3 & 3 \\
\hline Micrasterias rotata RALFS & mes & aci & ben & 1 & 2 \\
\hline Micrasterias thomasiana W.ARCHER & mes-oli & aci & ben & 3 & 1 \\
\hline Micrasterias thomasiana var. notata (NORDST.) GRÖNBLAD & mes-oli & aci & ben & & 1 \\
\hline Micrasterias truncata RALFS & oli-mes & aci & ben & & 1 \\
\hline Micrasterias truncata var. bahusiensis WITTR. & oli-mes & aci & ben & 2 & 1 \\
\hline Micrasterias truncata var. quadrata BULNH. & oli & aci & ben & 3 & 1 \\
\hline Micrasterias truncata var. semiradiata (NäGELI) WOLlE & oli-mes & aci & ben & 1 & 1 \\
\hline Netrium digitus Itzigs. et Rotне & oli-mes & aci & ben & & \\
\hline Netrium interruptum (RALFS) LÜTKEM. & mes & aci & ben & 2 & 2 \\
\hline Netrium interruptum var. minor (BORGE) WILLI KRIEG. & oli-mes & aci & ben-atm & 3 & \\
\hline Netrium oblongum (DE BARY) LÜTKEM. & oli & aci & ben-atm & 1 & 1 \\
\hline Netrium pseudactinotaenium COESEL & oli & aci & ben & 3 & 3 \\
\hline Penium cylindrus Ralfs & oli-mes & aci & ben & & \\
\hline Penium exiguum $\mathrm{W} . \mathrm{WeST}$ & mes-oli & aci & ben & 3 & 3 \\
\hline Penium margaritaceum RALFS & mes-oli & aci & ben & 1 & 1 \\
\hline Penium polymorphum PERTY & oli & aci & ben & 2 & 2 \\
\hline Penium spirostriolatum J.BARKER & mes-oli & aci & ben & 1 & 2 \\
\hline Pleurotaenium archeri DelPONTE & mes & aci & ben & 3 & 2 \\
\hline Pleurotaenium coronatum (RALFS) RABENH. & mes & aci & ben & 3 & 2 \\
\hline Pleurotaenium coronatum var. fluctuatum W.WEST & mes & aci & ben & 2 & 2 \\
\hline Pleurotaenium crenulatum (RALFS) RABENH. & mes & aci & ben & & \\
\hline Pleurotaenium ehrenbergii (RALFs) DE BARY & mes & aci & ben & & 1 \\
\hline Pleurotaenium eugeneum (W.B.TurNer) W. et G.S.WeST & mes & aci & ben & 3 & 2 \\
\hline Pleurotaenium nodulosum (RALFs) DE BARY & mes & aci & ben & 3 & 3 \\
\hline Pleurotaenium simplicissimum GRÖNBLAD & mes & aci & ben & 3 & 3 \\
\hline Pleurotaenium trabecula NäGELI & mes & aci-neu & ben & 1 & 1 \\
\hline Pleurotaenium tridentulum (Wolle) W.WeST & oli & aci & ben & 3 & 3 \\
\hline Pleurotaenium truncatum (RALFS) NäGELI & mes & aci & ben & 1 & 2 \\
\hline Roya cambrica W. et G.S.WeST & mes & aci & ben & 3 & \\
\hline Roya closterioides COESEL & mes & aci & ben & 2 & 2 \\
\hline
\end{tabular}


Table 1 Cont.

\begin{tabular}{|c|c|c|c|c|c|}
\hline & TRPH & ACID & LF & $\mathbf{R}$ & $\mathbf{S}$ \\
\hline Roya obtusa (BRÉB.) W. et G.S.WEST & oli & aci & atm-ben & & \\
\hline Roya obtusa var. anglica (G.S.West) WiLLI KRIEG. & oli & aci & atm-ben & & \\
\hline Sphaerozosma aubertianum W.WEST & mes & aci & ben & 3 & 3 \\
\hline Sphaerozosma filiforme RALFs & mes & aci-neu & ben & 3 & 3 \\
\hline Spirotaenia condensata RALFS & mes-oli & aci & atm-ben & & \\
\hline Spirotaenia endospira (BRÉB.) W.ARCHER & oli-mes & aci & atm-ben & 3 & \\
\hline Spirotaenia erythrocephala ITzIGs. & oli-mes & aci & atm-ben & 3 & \\
\hline Spondylosium planum (WolLe) W. et G.S.West & mes-eu & neu & pla-ben & 3 & \\
\hline Spondylosium pulchellum W.ARCHER & oli-mes & aci & ben & 1 & 2 \\
\hline Staurastrum aculeatum RALFS & mes & aci & ben & 3 & 3 \\
\hline Staurastrum alternans RALFS & mes & aci-neu & ben & & 1 \\
\hline Staurastrum arctiscon (RALFS) P.LuNDELL & mes & aci & pla & 3 & 3 \\
\hline Staurastrum arcuatum NORDST. & eu-mes & alk-neu & pla & 3 & \\
\hline Staurastrum avicula RALFS & mes-eu & aci-neu & ben-pla & 1 & 1 \\
\hline Staurastrum bieneanum RABENH. & mes & aci & ben & 1 & 1 \\
\hline Staurastrum bloklandiae CoESEL et JoOsteN & $\mathrm{eu}$ & alk & pla & 1 & \\
\hline Staurastrum bohlinianum SCHMIDLE & oli & aci & ben & 3 & \\
\hline Staurastrum boreale W. et G.S.WEST & mes & aci & ben & & \\
\hline Staurastrum borgeanum ScHMIDLE & oli-mes & aci & ben & 3 & \\
\hline Staurastrum brachiatum RALFS & oli-mes & aci & ben & 2 & 2 \\
\hline Staurastrum brebissonii W.ARCHER in A.PRITCH. & mes & aci & ben & 3 & 3 \\
\hline Staurastrum capitulum RALFS & oli-mes & aci & ben-atm & 2 & \\
\hline Staurastrum chaetoceras (SCHRÖDER) G.M.SMITH & $\mathrm{eu}$ & alk & pla & & \\
\hline Staurastrum controversum RALFS & mes & aci & ben & 1 & 2 \\
\hline Staurastrum crassangulatum COESEL & mes & aci & ben & 3 & 3 \\
\hline Staurastrum cristatum (NÄGELI) W.ARCHER & mes & aci & ben & 2 & 2 \\
\hline Staurastrum cristatum var. cuneatum HiNODE & mes & aci & ben & 3 & 3 \\
\hline Staurastrum cyrtocerum (BRÉB.) RALFS & mes & aci & ben & 2 & 1 \\
\hline Staurastrum dilatatum RALFS & mes & aci & ben & 3 & 2 \\
\hline Staurastrum dispar BRÉB. & mes & aci & ben & & 1 \\
\hline Staurastrum echinatum RALFS & oli & aci & ben-atm & 3 & \\
\hline Staurastrum erasum BRÉB. & mes & aci-neu & ben & 2 & 2 \\
\hline Staurastrum eurycerum SKUJA & eu-mes & neu-alk & pla-ben & 2 & 2 \\
\hline Staurastrum furcatum (RALFS) BRÉB. & oli & aci & ben & 2 & 2 \\
\hline Staurastrum furcatum var. aciculiferum (W.WEST) COESEL & oli & aci & ben & 2 & 2 \\
\hline Staurastrum furcigerum (RALFS) W.ARCHER & mes & aci-neu & ben-pla & 1 & 2 \\
\hline Staurastrum gracile RALFS & mes & aci & ben & & \\
\hline Staurastrum habeebense IRÉNÉE-MARIE & oli & neu & atm-ben & 3 & \\
\hline Staurastrum hirsutum RALFS & oli & aci & ben & & \\
\hline Staurastrum hirsutum var. arnellii (BOLDT) COESEL & oli & aci & ben & 3 & \\
\hline Staurastrum hirsutum var. muricatum (RALFS) KURT FöRST. & oli & aci & ben & & \\
\hline Staurastrum hystrix RALFS & oli & aci & ben & 3 & 3 \\
\hline Staurastrum inflexum BRÉB. & mes-oli & aci-neu & ben & & 1 \\
\hline
\end{tabular}


Table 1 Cont.

\begin{tabular}{|c|c|c|c|c|c|}
\hline & TRPH & ACID & $\mathbf{L F}$ & $\mathbf{R}$ & $\mathbf{S}$ \\
\hline Staurastrum kouwetsii COESEL & mes & aci & ben & 1 & 2 \\
\hline Staurastrum lapponicum (SCHMIDLE) GRÖNBLAD & mes & aci & ben & 1 & 2 \\
\hline Staurastrum lunatum RALFS & mes & aci & ben & 2 & 1 \\
\hline Staurastrum manfeldtii DELPONTE & mes & aci-neu & ben & 2 & 2 \\
\hline Staurastrum margaritaceum RALFS & oli & aci & ben & & \\
\hline Staurastrum meriani REINSCH & oli & aci & ben-atm & 3 & \\
\hline Staurastrum micron W. et G.S.WEST & oli-mes & aci & ben & 2 & 1 \\
\hline Staurastrum minimum COESEL & oli-mes & aci & ben & 3 & 3 \\
\hline Staurastrum muticum RALFS & mes & aci & ben & 1 & 2 \\
\hline Staurastrum oligacanthum W.ARCHER & mes & aci & ben & 3 & 3 \\
\hline Staurastrum orbiculare RALFS & mes & aci & ben & 3 & 3 \\
\hline Staurastrum orbiculare var. depressum J.RoY et BISSET & mes-eu & neu-aci & ben & & \\
\hline Staurastrum orbiculare var. extensum NORDST. & oli-mes & aci & ben-atm & 2 & \\
\hline Staurastrum orbiculare var. ralfsii W. et G.S.WEST & mes & aci & ben & 3 & \\
\hline Staurastrum oxyacanthum W.ARCHER & mes & aci & ben & 3 & 3 \\
\hline Staurastrum pentasterias GRÖNBLAD & mes & aci & ben & 3 & 2 \\
\hline Staurastrum pileolatum BRÉB. & oli & aci & ben-atm & 2 & \\
\hline Staurastrum pingue TEILING & eu-mes & alk-neu & pla & & \\
\hline Staurastrum planctonicum TeILING & eu-mes & alk-neu & pla & & \\
\hline Staurastrum podlachicum B.EICHLER et GUTw. & mes & aci & ben & 3 & 3 \\
\hline Staurastrum polymorphum RALFS & mes & aci & ben & & \\
\hline Staurastrum polymorphum var. pygmaeum GRÖNBLAD & mes & aci & ben & 1 & 2 \\
\hline Staurastrum polytrichum (РERTY) RABENH. & mes & aci & ben & 1 & 2 \\
\hline Staurastrum proboscideum (RALFS) W.ARCHER var. productum MESSIK. & mes & aci & ben & 2 & 1 \\
\hline Staurastrum punctulatum $\mathrm{RALFS}$ & oli & aci & ben & & \\
\hline Staurastrum punctulatum var. muricatiforme SCHMIDLE & oli & aci & ben-atm & 2 & \\
\hline Staurastrum punctulatum var. pygmaeum (RALFS) W. et G.S.WEST & oli & aci & ben-atm & 3 & \\
\hline Staurastrum pungens $\mathrm{RALFS}$ & mes & aci & ben & 3 & 3 \\
\hline Staurastrum pyramidatum W.WEST & oli & aci & ben & 3 & 3 \\
\hline Staurastrum quadrispinatum W.B.TURNER & oli & aci & ben & 3 & 3 \\
\hline Staurastrum retusum W.B.TURNER var. boreale W. et G.S.WEST & eu-mes & neu-alk & ben & 3 & 2 \\
\hline Staurastrum scabrum RALFS & oli & aci & ben & 3 & 3 \\
\hline Staurastrum sebaldi REINSCH & mes & aci & ben & 3 & 3 \\
\hline Staurastrum sebaldi var. gracile MEssIK. & mes & aci & ben & 3 & 3 \\
\hline Staurastrum senarium RALFS & mes & aci & ben & 3 & 2 \\
\hline Staurastrum setigerum CLEVE & mes & aci & ben & 3 & 2 \\
\hline Staurastrum sexcostatum RALFS & oli-mes & aci & ben-atm & 2 & \\
\hline Staurastrum sexcostatum var. productum W.WEST & mes & aci & ben & 1 & \\
\hline Staurastrum simonyi HeIMERL & oli & aci & ben & 1 & 2 \\
\hline Staurastrum simonyi var. gracile LÜткем. & oli & aci & ben & 3 & 2 \\
\hline Staurastrum simonyi var. semicirculare COESEL & oli & aci & ben & 1 & 2 \\
\hline Staurastrum smithii (G.M.SмITH) TEILING & eu & alk & pla & 3 & \\
\hline Staurastrum spongiosum RALFS & oli-mes & aci & ben-atm & 3 & 2 \\
\hline Staurastrum spongiosum var. perbifidum W.WEST & oli-mes & aci & ben-atm & 3 & 2 \\
\hline
\end{tabular}


Table 1 Cont.

\begin{tabular}{|c|c|c|c|c|c|}
\hline & TRPH & ACID & $\mathbf{L F}$ & $\mathbf{R}$ & $\mathbf{S}$ \\
\hline Staurastrum striatum (W. et G.S.WEST) RỦžǏČ & mes & aci-neu & ben & & \\
\hline Staurastrum striolatum (NÄGELI) W.ARCHER & mes & aci & ben & 2 & 2 \\
\hline Staurastrum subarcuatum WoLLE & mes & aci & ben-pla & 3 & 2 \\
\hline Staurastrum subavicula (W.WEST) W. et G.S.WEST & mes-oli & aci & ben & 2 & 2 \\
\hline Staurastrum teliferum RALFS & mes & aci & ben & & 2 \\
\hline Staurastrum tetracerum RALFS & mes-eu & neu-aci & ben & & 1 \\
\hline Staurastrum tetracerum var. subexcavatum GRÖNBLAD & $\mathrm{eu}$ & alk & pla & 2 & \\
\hline Staurastrum trapezicum BoLDT & mes & aci & ben & 3 & 3 \\
\hline Staurastrum varians RACIB. & mes & aci & ben & 3 & 3 \\
\hline Staurastrum vestitum RALFS & mes & aci & ben & 3 & 3 \\
\hline Staurodesmus brevispina (RALFS) CROASDALE & mes & aci-neu & ben & 3 & 2 \\
\hline Staurodesmus convergens (RALFs) S.LiLL. & mes & aci & ben & 1 & 2 \\
\hline Staurodesmus cuspidatus (RALFs) TeILING & mes & aci-neu & ben-pla & 1 & 1 \\
\hline Staurodesmus cuspidatus var. divergens (NoRDST.) COESEL & eu-mes & alk-neu & pla-ben & & \\
\hline Staurodesmus dejectus (RaLfs) TeILING & mes & aci-neu & ben & 1 & 1 \\
\hline Staurodesmus dejectus var. apiculatus (BRÉB.) TeILING & mes & aci-neu & ben & 1 & 1 \\
\hline Staurodesmus dejectus var. robustus (MessiK.) CoESEL & mes & neu & ben & 3 & 1 \\
\hline Staurodesmus dickiei (RALFs) S.LILL. & mes & aci & ben & 2 & 2 \\
\hline Staurodesmus dickiei var. circularis (W.B.TURNER) CROASDALE & mes & aci & ben & 3 & 2 \\
\hline Staurodesmus extensus (BORGE) TEILING & mes & aci-neu & ben-pla & 1 & 1 \\
\hline Staurodesmus extensus var. isthmosus (HeIMERL) COESEL & oli-mes & aci & ben & 2 & 2 \\
\hline Staurodesmus extensus var. joshuae (Gutw.) TeILING & oli-mes & aci & ben & 3 & 2 \\
\hline Staurodesmus extensus var. malaccensis (BERNARD) COESEL & oli & aci & ben & 3 & 2 \\
\hline Staurodesmus extensus var. vulgaris (B.EICHLER et RACIB.) CROASDALE & mes & aci & ben & & 1 \\
\hline Staurodesmus glaber (RALFS) TEILING & mes-oli & aci & ben & & 2 \\
\hline Staurodesmus incus (BRÉB.) TeILING & oli-mes & aci & ben & 1 & \\
\hline $\begin{array}{l}\text { Staurodesmus lanceolatus (W.ARCHER) CROASDALE var. compressus (W. et } \\
\text { G.S.WEST) TEILING }\end{array}$ & mes-oli & aci & ben & 3 & 3 \\
\hline Staurodesmus mucronatus (BRÉB.) CROASDALE & mes & aci & ben & 3 & 2 \\
\hline Staurodesmus omearae (W.ARCHER) TEILING & mes-oli & aci & ben & & \\
\hline Staurodesmus patens (NORDST.) CROASDALE & mes & neu-aci & ben & 1 & 2 \\
\hline Staurodesmus spencerianus (MASK.) TeILING & oli & aci & ben & 3 & 2 \\
\hline Staurodesmus subhexagonus (W. et G.S.WEST) COESEL & oli-mes & aci & ben & 3 & 2 \\
\hline Teilingia excavata (RALFs) BoURR. & mes & aci & ben & 1 & 1 \\
\hline Teilingia granulata (J.Roy et BISSET) BOURR. & mes-eu & aci-alk & ben-pla & & 1 \\
\hline Tetmemorus brebissonii RALFS & oli & aci & ben & 2 & 2 \\
\hline Tetmemorus brebissonii var. minor DE BARY & oli & aci & ben & 2 & 2 \\
\hline Tetmemorus granulatus RALFS & mes-oli & aci & ben & & 1 \\
\hline Tetmemorus laevis RALFS & oli & aci & ben-atm & & \\
\hline Tetmemorus laevis var. minutus (De BarY) Willi KrIEG. & oli & aci & ben-atm & 1 & \\
\hline Tortitaenia bahusiensis (NoRdST. et LÜTKEM.) COESEL & oli-mes & neu & atm-ben & 3 & \\
\hline Tortitaenia obscura (RALFs) BROOK & oli-mes & aci & atm-ben & & \\
\hline Xanthidium aculeatum EHRENB. & mes-oli & aci & ben & 3 & \\
\hline Xanthidium antilopaeum Küтz. & mes & aci-neu & ben-pla & 1 & 1 \\
\hline Xanthidium antilopaeum var. laeve ScHMidLE & oli & aci & ben-pla & 2 & 3 \\
\hline
\end{tabular}


Table 1 Cont.

\begin{tabular}{|c|c|c|c|c|c|}
\hline & TRPH & ACID & $\mathbf{L F}$ & $\mathbf{R}$ & $\mathbf{S}$ \\
\hline $\begin{array}{l}\text { Xanthidium antilopaeum var. herbidarum W. et G.S.WeST forma javanicum } \\
\text { (NoRDSt.) COESEL }\end{array}$ & mes & aci-neu & ben-pla & 2 & 1 \\
\hline Xanthidium antilopaeum var. planum RoLl & mes & aci & ben-pla & 2 & 1 \\
\hline Xanthidium armatum RALFS & oli & aci & ben & 2 & 3 \\
\hline Xanthidium basidentatum (BørGEs.) COEsel & mes & aci & ben & 3 & 3 \\
\hline Xanthidium bifidum (BrÉB.) Deflandre & mes & aci & ben & 3 & 3 \\
\hline Xanthidium concinnum W.ARCHER & mes & aci & ben & 3 & 3 \\
\hline Xanthidium cristatum RALFS & mes & aci & ben & 3 & 3 \\
\hline Xanthidium cristatum var. uncinatum RALFs forma polonicum GuTw. & mes & neu & ben & 3 & 3 \\
\hline Xanthidium fasciculatum RALFS var. oronense W. et G.S.WeST & mes & aci & ben & 3 & 3 \\
\hline Xanthidium octocorne RALFS & mes-oli & aci & ben & 1 & 2 \\
\hline
\end{tabular}

(C) Czech Phycological Society

Received June 3, 2009

Accepted August 10, 2009 